Prepared in cooperation with the U.S. Environmental Protection Agency

\title{
Trends in Concentrations, Loads, and Sources of Trace Metals and Nutrients in the Spokane River Watershed, Northern Idaho, Water Years 1990-2018
}
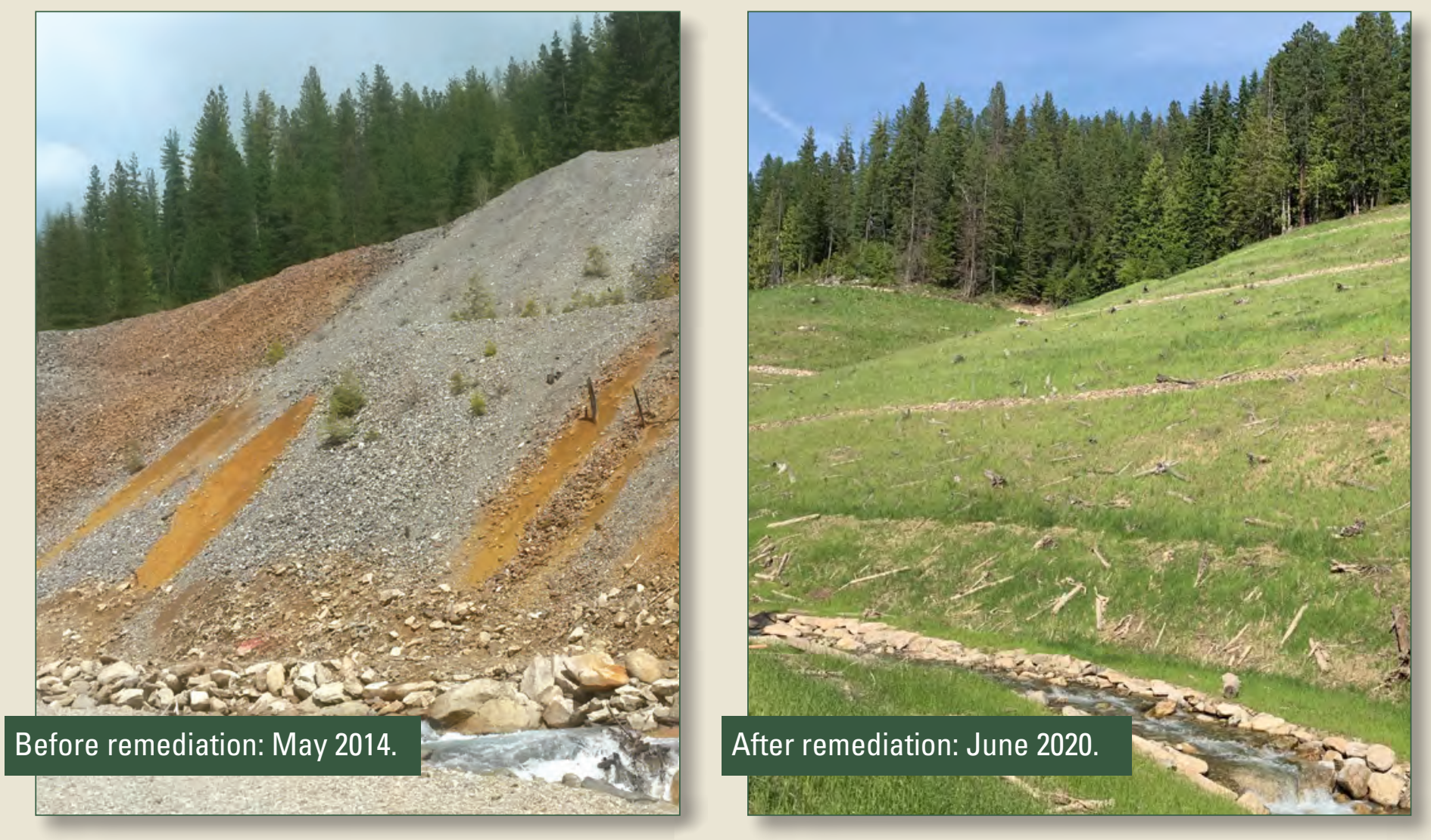

Scientific Investigations Report 2020-5096 


\section{Cover.}

Left photograph (before): Waste piles at Success Mine adjacent to East Fork of Ninemile Creek before remediation, May 2014.

Right photograph (after): Graded and re-vegetated hill at Success Mine after remediation, June 2020. Photographs by the Successor Coeur d'Alene Custodial and Work Trust. 


\section{Trends in Concentrations, Loads, and Sources of Trace Metals and Nutrients in the Spokane River Watershed, Northern Idaho, Water Years 1990-2018}

By Lauren M. Zinsser

Prepared in cooperation with the U.S. Environmental Protection Agency

Scientific Investigations Report 2020-5096 


\title{
U.S. Department of the Interior \\ DAVID BERNHARDT, Secretary
}

\author{
U.S. Geological Survey \\ James F. Reilly II, Director
}

U.S. Geological Survey, Reston, Virginia: 2020

For more information on the USGS - the Federal source for science about the Earth, its natural and living resources, natural hazards, and the environment—visit https://www.usgs.gov or call 1-888-ASK-USGS.

For an overview of USGS information products, including maps, imagery, and publications, visit https://store.usgs.gov/.

Any use of trade, firm, or product names is for descriptive purposes only and does not imply endorsement by the U.S. Government.

Although this information product, for the most part, is in the public domain, it also may contain copyrighted materials as noted in the text. Permission to reproduce copyrighted items must be secured from the copyright owner.

Suggested citation:

Zinsser, L.M., 2020, Trends in concentration, loads, and sources of trace metals and nutrients in the Spokane River Watershed, northern Idaho, water years 1990-2018: U.S. Geological Survey Scientific Investigations Report 2020-5096, 58 p., https://doi.org/10.3133/sir20205096.

ISSN 2328-0328 (online) 


\section{Contents}

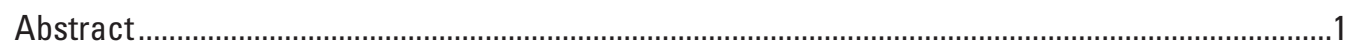

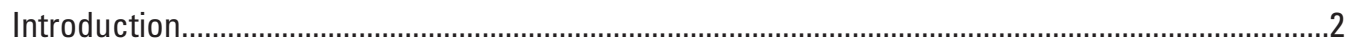

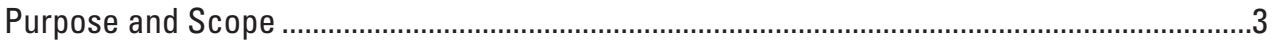

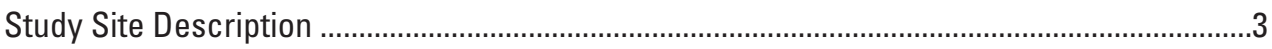

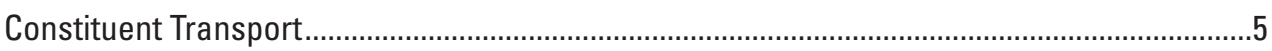

Approaches for Load Calculation and Trend Detection ........................................................

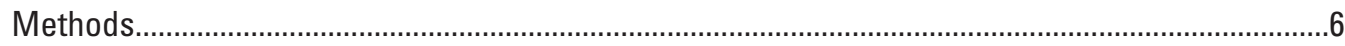

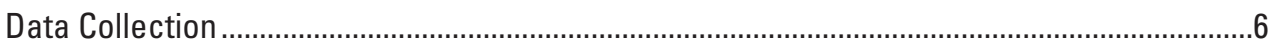

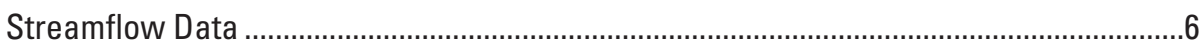

Water-Quality Data for Water Years 1990-2003 ............................................................10

Water-Quality Data for Water Years 2004-18 ....................................................................11

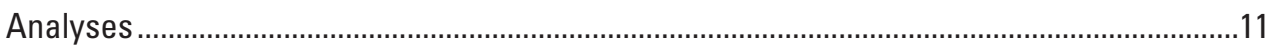

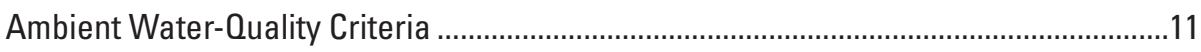

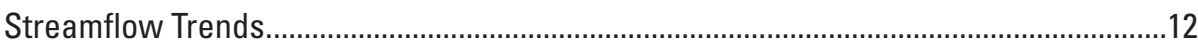

Water Quality: Concentrations, Loads, and Trends.....................................................12

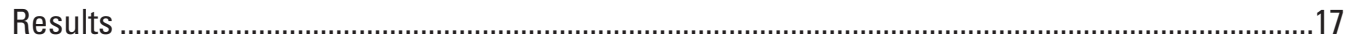

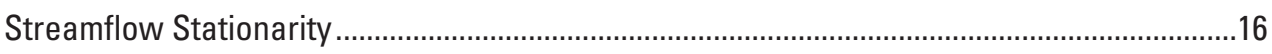

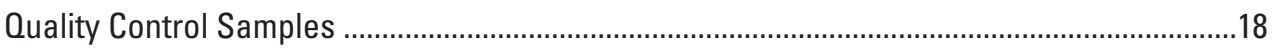

Comparisons to Ambient Water-Quality Criteria .................................................................19

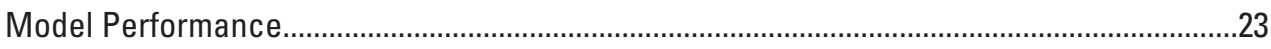

Trends in Concentrations and Loads ...........................................................................2

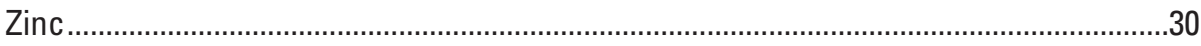

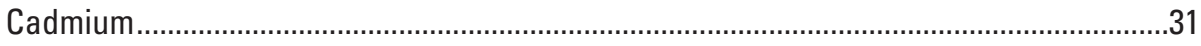

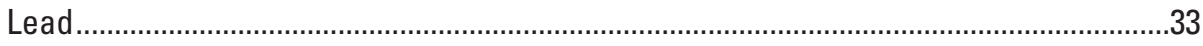

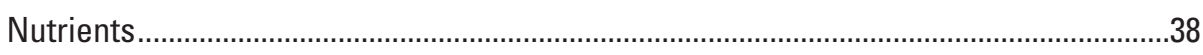

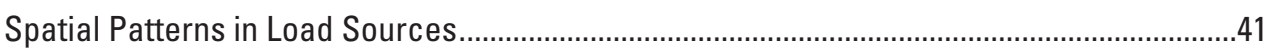

South Fork Coeur d'Alene River ..................................................................................41

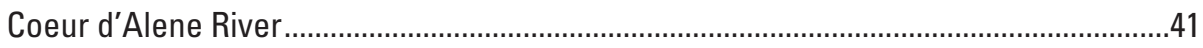

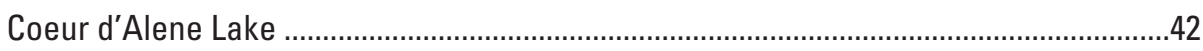

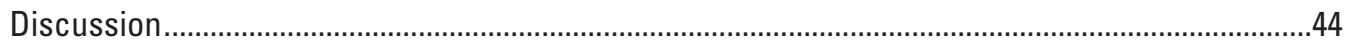

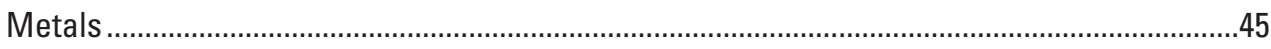

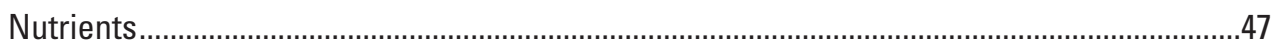

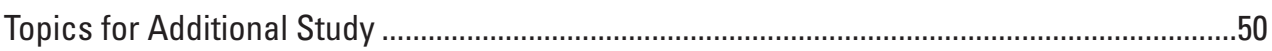

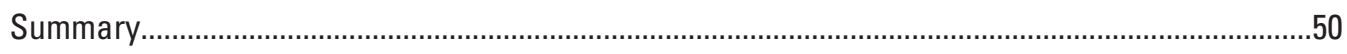

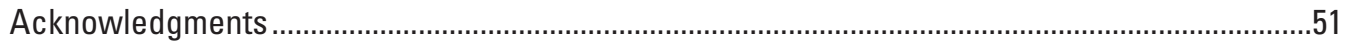

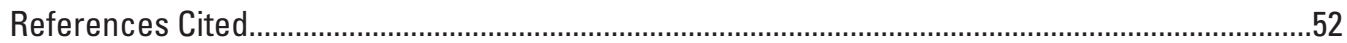

Appendix 1 Summary Graphs Showing Weighted Regressions on Time, Discharge and Season (WRTDS) and Weighted Regressions on Time, Discharge and Season with Kalman Filtering (WRTDS_K) Modeled Annual Concentrations and Loads ................57

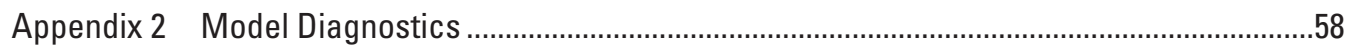




\section{Figures}

1. Maps showing study area and sampling sites, Spokane River watershed, northern Idaho.

2. Quantile-Kendall plots showing trends in streamflow for water years 1990-2018 for select sites in the Spokane River watershed, northern Idaho.

3. Boxplots showing dissolved zinc ambient water-quality criteria ratios for water years 1990-2018 for sites in the Spokane River watershed, northern Idaho

4. Boxplots showing dissolved cadmium ambient water-quality criteria ratios for water years 1990-2018 for sites in the Spokane River watershed, northern Idaho .......24

5. Boxplots showing dissolved lead ambient water-quality criteria ratios for water years 1990-2018 for sites in the Spokane River watershed, northern Idaho

6. Box plots showing flux bias statistics associated with Weighted Regressions on Time, Discharge and Season models for water years 1990-2018, grouped by parameter and site, Spokane River watershed, northern Idaho

7. Boxplots showing annual mean concentrations and loads for cadmium, lead and zinc from Weighted Regressions on Time, Discharge and Season with Kalman filtering models for water years 2014-18 for sites in the Spokane River watershed, northern Idaho

8. Graphs showing dissolved zinc annual mean concentrations and annual total loads from Weighted Regressions on Time, Discharge and Season with Kalman filtering and flow-normalized annual mean concentrations and annual total loads from Weighted Regressions on Time, Discharge and Season for select sites in the Spokane River watershed, northern Idaho, water years 1990-2018

9. Schematic showing statistical likelihood and magnitude of change in flow-normalized dissolved zinc concentrations and annual total loads over the period of record and water years 2009-18 for sites in the Spokane River watershed, northern Idaho

10. Graphs showing change in load per year and 90 percent confidence intervals for select constituents and sites in the Spokane River watershed, northern Idaho.......33

11. Graphs showing dissolved cadmium annual mean concentrations and annual total loads from Weighted Regressions on Time, Discharge and Season with Kalman filtering and flow-normalized annual mean concentrations and annual total loads from Weighted Regressions on Time, Discharge and Season for select sites in the Spokane River watershed, northern Idaho

12. Schematic showing statistical likelihood and magnitude of change in flow-normalized dissolved cadmium concentrations and loads over the period of record and water years 2009-18 for sites in the Spokane River watershed, northern Idaho.

13. Graphs showing total lead annual mean concentrations and annual total loads from Weighted Regressions on Time, Discharge and Season with Kalman filtering and flow-normalized annual mean concentrations and annual total loads from Weighted Regressions on Time, Discharge and Season for select sites in the Spokane River watershed, northern Idaho.

14. Graphs showing statistical likelihood and magnitude of change in flow-normalized total lead concentrations and loads over the period of record and water years 2009-18 for sites in the Spokane River watershed, northern Idaho ....37 
15. Graphs showing total phosphorus annual mean concentrations and annual total loads from Weighted Regressions on Time, Discharge and Season with Kalman filtering and flow-normalized annual mean concentrations and annual total loads from Weighted Regressions on Time, Discharge and Season for select sites in the Spokane River watershed, northern Idaho, water years 1990-2018

16. Schematics showing statistical likelihood and magnitude of change in flow-normalized total phosphorus concentrations and loads over the period of record and water years 2009-18 for sites in the Spokane River watershed, northern Idaho...

17. Graphs showing incremental annual total loads for sites in the South Fork Coeur d'Alene River, northern Idaho, water years 1999-2018

18. Graphs showing incremental annual total loads for the South Fork Coeur d'Alene River, the North Fork Coeur d'Alene River, and the main-stem Coeur d'Alene River, northern Idaho, water years 1994-2018

19. Graphs showing annual total loads into and out of Coeur d'Alene Lake, northern Idaho, water years $2005-18$

\section{Tables}

1. Streamgaging and water-quality monitoring sites and data used for analyses, Spokane River watershed, northern Idaho

2. Example ambient water-quality criteria for different sample hardness, South

Fork Coeur d'Alene River-specific and Idaho state-wide criteria

3. Summary of site, parameters, water years, and samples used for Weighted Regressions on Time, Discharge and Season (WRTDS) and WRTDS with Kalman filtering (WRTDS_K) models, and flux bias statistics for WRTDS models...

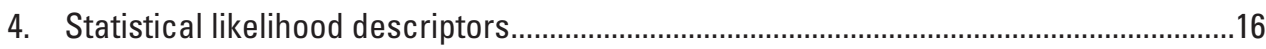

5. Summary of blank sample results, water years 1997-2018 ……...................................18

6. Summary of replicate sample results, water years 1997-2018.....................................19

7. Median ambient water-quality criteria ratios for dissolved cadmium, lead and zinc, water years 1990-2018, for sites in the Spokane River watershed, northern Idaho.

8. Five year mean of annual mean concentrations for total and dissolved constituents derived from Weighted Regression on Time, Discharge and Season with Kalman filtering models for sites in the Spokane River watershed, northern Idaho, water years 2014-18. 


\section{Conversion Factors}

U.S. customary units to International System of Units

\begin{tabular}{|c|c|c|}
\hline Multiply & By & To obtain \\
\hline \multicolumn{3}{|c|}{ Length } \\
\hline mile (mi) & 1.609 & kilometer $(\mathrm{km})$ \\
\hline \multicolumn{3}{|c|}{ Area } \\
\hline square mile $\left(\mathrm{mi}^{2}\right)$ & 2.590 & square kilometer $\left(\mathrm{km}^{2}\right)$ \\
\hline \multicolumn{3}{|c|}{ Flow rate } \\
\hline cubic foot per second $(\mathrm{ft} 3 / \mathrm{s})$ & 0.02832 & cubic meter per second $\left(\mathrm{m}^{3} / \mathrm{s}\right)$ \\
\hline
\end{tabular}

International System of Units to U.S. customary units

\begin{tabular}{|c|c|c|}
\hline Multiply & By & To obtain \\
\hline \multicolumn{3}{|c|}{ Volume } \\
\hline liter $(\mathrm{L})$ & 0.2642 & gallon (gal) \\
\hline \multicolumn{3}{|c|}{ Mass } \\
\hline gram (g) & 0.03527 & ounce, avoirdupois (oz) \\
\hline kilogram (kg) & 2.205 & pound avoirdupois (lb) \\
\hline metric ton $(\mathrm{t})$ & 1.102 & ton, short [2,000 lb] \\
\hline metric ton $(\mathrm{t})$ & 0.9842 & ton, long [2,240 lb] \\
\hline
\end{tabular}

\section{Datums}

Vertical coordinate information is referenced to the North American Vertical Datum of 1988 (NAVD 88).

Horizontal coordinate information is referenced to the North American Datum of 1983 (NAD 83).

Elevation, as used in this report, refers to distance above the vertical datum.

\section{Supplemental Information}

Concentrations of chemical constituents in water are given in micrograms per liter $(\mu \mathrm{g} / \mathrm{L})$. 


\title{
Abbreviations
}

\author{
ADVM acoustic Doppler velocity meter \\ AWOC ambient water-quality criteria \\ CDR Coeur d'Alene River \\ EGRET Exploration and Graphics for RivEr Trends \\ EPA U.S. Environmental Protection Agency \\ NFCDR North Fork Coeur d'Alene River \\ SFCDR South Fork Coeur d'Alene River \\ USGS U.S. Geological Survey \\ WRTDS Weighted Regressions on Time, Discharge and Season \\ WRTDS_K Weighted Regressions on Time, Discharge and Season with Kalman filtering \\ WY water year
}


This page intentionally left blank. 


\title{
Trends in Concentrations, Loads, and Sources of Trace Metals and Nutrients in the Spokane River Watershed, Northern Idaho, Water Years 1990-2018
}

\author{
By Lauren M. Zinsser
}

\section{Abstract}

A long history of mining and widespread metals contamination in the Coeur d'Alene River watershed and downstream into the Spokane River has led to the area's designation as a Superfund site and to extensive, ongoing (as of 2020) remedial actions. Long-term water-quality and streamflow data, collected by the U.S. Geological Survey for up to 29 years at 20 sampling sites in the Coeur d'Alene, Spokane and St. Joe River watersheds, were analyzed to evaluate the impact of remedial actions on metals in surface water. Analyses focused on total and dissolved cadmium, zinc and lead. Trends in total phosphorus, total nitrogen and dissolved orthophosphate were also evaluated; although these nutrients are not constituents of concern for the Superfund site, they are important to the health of Coeur d'Alene Lake.

Dissolved cadmium, zinc and lead concentrations were compared to ambient water-quality criteria at 20 sample sites. For the 12 sites with the most extensive data records, Weighted Regressions on Time, Discharge and Season (WRTDS) models were developed to estimate flownormalized annual mean concentrations and flow-normalized annual total loads; these results were used to evaluate trends because flow-normalization dampens the impact of interannual streamflow variability on concentrations and loads. WRTDS models with Kalman filtering (WRTDS_K) were developed to estimate annual mean concentrations and annual total loads; these results were used to evaluate spatial patterns in constituent sources. Models were developed for total and dissolved cadmium, lead, and zinc; total phosphorus and nitrogen; and dissolved orthophosphate, although not all constituents were modeled for all sites due to limited sample sizes. Bootstrapped confidence intervals were constructed to determine the statistical likelihood of trends and the slope of trends in flow-normalized concentrations and loads during the period of record (13-29 years, depending on the site), water years 1999-2009, and water years 2009-18.

A feature of trend analysis with WRTDS is the ability to translate the outcomes of the likelihood statistical tests into plain language. As used throughout this report, a trend was considered "likely up" when the likelihood statistic was between 0.85 and 1.0 ; that is, when the probability that the trend is up was greater than or equal to 0.85 . Conversely, a trend with a likelihood statistic of 0 to 0.15 was considered "likely down" because a low probability that a trend is up is equivalent to a high probability that the trend is actually down. A trend was "somewhat likely up" when the likelihood statistic was between 0.70 and 0.85 , and "somewhat likely down" for values between 0.15 and 0.30 . Finally, a trend was considered "about as likely as not" - essentially a statistical toss-up - when the likelihood statistic was between 0.30 and 0.70 .

Total and dissolved cadmium and zinc concentrations and loads have decreased with high statistical likelihood at virtually all mining-affected sites over both the period of record and water years 2009-18. During the period of record, total and dissolved zinc and cadmium concentrations and loads decreased about 25-75 percent with "likely down" trends. The decreases in total and dissolved zinc and cadmium concentrations and loads persisted with high statistical likelihood ("likely down" trends) during water years 2009-18 although the absolute magnitude of the decreases was lower (about 10-30 percent). The magnitude of ambient water-quality criteria exceedances for dissolved cadmium, zinc and lead also decreased at most mining-affected sites over the period of record, though concentrations remain above chronic criteria at most sites.

Although trend analyses inherently cannot ascribe causality, the trends in metals are consistent with processes of metal transport and the occurrence of remedial actions across the Superfund site. Early remedial actions focused on removing source materials from streams and floodplains in the South Fork Coeur d'Alene River and tributaries; the removal of these primary and stream-proximal materials aligns with the period of steepest declines in metals concentrations and loads. Slower decreases in metals concentrations and loads in water years 2009-18 suggest that remedial actions continue to positively impact water quality but that pervasive secondary sources of metals (for example, in groundwater and fluvial sediments) may be responding more slowly. Thus, trend analyses are strong evidence that extensive remedial actions across the Superfund site have improved water quality at most sites through reductions in cadmium and zinc. 
Total and dissolved lead concentrations and loads have also decreased at most mining-affected sites over the period of record and during water years 2009-18. At most miningaffected sites, total and dissolved lead concentrations and loads had "likely down" trends of about 20-85 percent over the period of record and had "likely down" or "somewhat likely down" trends of about 10-50 percent during water years 2009-18. However, "somewhat likely up" trends for total lead occurred in the Coeur d'Alene River near Harrison over the period of record. These results suggest that source removals for particulate lead in the upper parts of the Coeur d'Alene River watershed have resulted in decreasing total lead loads for most sites, but substantial remaining particulate lead sources lower in the watershed (where major removal actions have not yet begun) continue to affect water quality in the main-stem Coeur d'Alene River.

Incremental load analyses illustrate patterns in metal sources across the study area, and point to areas that may warrant investigation for potential future remedial actions. Substantial loading of total lead in the South Fork Coeur d'Alene River above Elizabeth Park may be related to tailings in Osburn Flats. The incremental annual total loads for the Coeur d'Alene River near Harrison (which was considered a proxy for total load delivered to Coeur d'Alene Lake) indicate that the South Fork Coeur d'Alene River remained the source of the majority of dissolved zinc and cadmium loads to Coeur d'Alene Lake, whereas the main-stem Coeur d'Alene River remained the source of the majority of the total and dissolved lead loads. Widely dispersed particulate contaminants in the river beds, banks, and floodplains of the main-stem Coeur d'Alene River system are a continuing source of particulate metals during high streamflows and, in conjunction with geochemical processes, are also a continuing source of dissolved metals. Future remedial actions in the main-stem Coeur d'Alene River are being planned to address these sources.

Trends in total phosphorus were temporally and spatially variable in the study area over the analysis period. Total phosphorus concentrations and loads had "likely up" or "somewhat likely up" trends in the South Fork Coeur d'Alene River near Pinehurst and Coeur d'Alene River near Harrison over the period of record but had "likely down" or "somewhat likely down" load trends at these sites during water years 2009-18. Differences in the magnitude of the change and river characteristics at these sites, and a lack of trends in other parts of the study area, suggest that local processes and mechanisms may be most important for driving trends. Analysis of the incremental annual total loads at these sites shows that the biggest total phosphorus loads occur during high streamflows years, which indicates that the main phosphorus sources are active during runoff conditions. In the steeper, more developed South Fork Coeur d'Alene River floodplain, trends could be related to surface runoff that has decreased over time due to remedial actions to stabilize hillslopes and increase riparian vegetation. In the productive, low-gradient main-stem Coeur d'Alene River, trends could be related to channel changes following near-record flooding in the 1990s that made total phosphorus more accessible for transport in the 2000s. However, interpretation of the total phosphorus trends is fundamentally limited by sparse datasets and a lack of mechanistic understanding of nutrient transport in the study area.

In summary, robust trend analyses of long-term waterquality monitoring data suggest that remedial actions have decreased metal concentrations and loads in the Coeur d'Alene and Spokane Rivers during both longer (13-29 years) and more recent (2009-18) periods. Sites with increasing or unclear trends in concentrations and loads, particularly for total lead, and spatial patterns in contaminant loading, may point to areas for focusing future remedial efforts.

\section{Introduction}

The Coeur d'Alene River watershed has a long and complicated history of mining, metals transport, and remedial activities. Once a globally important source of silver, lead, and zinc, mining in the Coeur d'Alene district began in the late 1800 s and continues today (2020), having produced millions of metric tons of lead and zinc and over a billion ounces of silver (Springer, 1997; Gillerman, 2019). Long (1998) estimated that production of the ore generated 109 million metric tons of mill tailings waste, of which about 56 million metric tons were "disposed of or otherwise lost into the Coeur d'Alene River or its tributaries" prior to cessation of direct dumping in 1968. These metal-laced tailings, containing zinc, cadmium, lead, arsenic, and copper, are widely dispersed throughout the Coeur d'Alene River fluvial system, including tributaries, the main-stem Coeur d'Alene River floodplain, the bottom of Coeur d'Alene Lake, and downstream into the Spokane River. Additional mine-related wastes also remain pervasive on land surfaces throughout the Coeur d'Alene River watershed as a direct result of hundreds of mining operations, the redistribution of metals-contaminated sediment via natural and humancaused processes, and the historical reuse of waste materials as road beds, railroad ballast, and fill (Long, 1998; U.S. Environmental Protection Agency, 2002, 2012b).

Listed by the U.S. Environmental Protection Agency (EPA) on the National Priorities List in 1983 (U.S. Environmental Protection Agency, 1992), the affected area is formally named the Bunker Hill Mining and Metallurgical Complex Superfund Site (hereinafter, "the Bunker Hill Superfund Site"). Collectively, the Bunker Hill Superfund Site encompasses all areas of the Coeur d'Alene and Spokane River watersheds affected by mining-related contamination, an area which stretches across the northern Idaho panhandle and into eastern Washington (fig. 1). Although multiple contaminants of concern have been identified by the various Records of Decision (U.S. Environmental Protection Agency, 1992, 2002, 2012b), this report focuses on total and dissolved zinc, cadmium, and lead. These metals occur at high concentrations in surface waters throughout the Bunker Hill Superfund Site and have long been recognized (U.S. Environmental 
Protection Agency, 1992) and prioritized for remedial actions (U.S. Environmental Protection Agency, 2002). This report also presents analyses for total phosphorus, total nitrogen, and dissolved orthophosphate. None of these nutrients were identified as a contaminant of concern in the various Records of Decisions, but they are of particular interest because of their importance to maintaining the health of Coeur d'Alene Lake (Idaho Department of Environmental Quality and Coeur d'Alene Tribe, 2009). Approximately 75 million metric tons of metals-contaminated sediment lie on the bottom of Coeur d'Alene Lake (Horowitz and others, 1995). The 2002 Record of Decision did not select a remedy for Coeur d'Alene Lake (U.S. Environmental Protection Agency, 2002), instead deferring to the development of the Coeur d'Alene Lake Management Plan, which aims to limit nutrients entering the lake in order to maintain oxygenated bottom water and therefore prevent mobilization of metals from benthic sediments (Idaho Department of Environmental Quality and Coeur d'Alene Tribe, 2009). Recent analyses indicate that total phosphorus concentrations are increasing in Coeur d'Alene Lake (Idaho Department of Environmental Quality and Coeur d'Alene Tribe, 2019), heightening concern about nutrient trends in the Coeur d'Alene Lake watershed.

Remedial actions at the Bunker Hill Superfund Site began in 1989, guided by a series of Record of Decision documents and associated technical studies (U.S. Environmental Protection Agency, 2012a). Given the scope and complexity of metals contamination in the Bunker Hill Superfund Site, the EPA is following an adaptive management approach and refraining from selecting final remedies in some areas (U.S. Environmental Protection Agency, 2002; National Research Council of the National Academies, 2005; U.S. Environmental Protection Agency, 2012b). As part of the adaptive management approach, the EPA works with various entities to conduct extensive monitoring of various media throughout the Coeur d'Alene River watershed. This report addresses one component of this effort by describing long-term trends based on surface water monitoring.

\section{Purpose and Scope}

The U.S. Geological Survey (USGS) has conducted streamgaging and water-quality monitoring in the Coeur d'Alene, Spokane, and St. Joe River watersheds (hereinafter, "the study area") in cooperation with the EPA and other entities since 1990. This report, which incorporates all these data, focuses on the statistical analysis of and description of trends from water year' (WY) 1990 through 2018, focusing on select metals (total and dissolved cadmium, lead, and zinc) and nutrients (total phosphorus, total nitrogen, and dissolved orthophosphate). These analyses build on an extensive body of previous works that described metal transport mechanisms, concentration and loading attributes, and trends in the study area from WY 1990 through WY 2013. The analyses in this report sought to address how remedial actions in the Bunker Hill Superfund Site are affecting key metals by asking if concentrations and loads are going down and if spatial patterns in load sources are changing.

\section{Study Site Description}

The Spokane River watershed comprises the Coeur d'Alene River (CDR) and St. Joe River watersheds. The main-stem CDR is formed at the confluence of its two major branches (fig. 1), the North Fork Coeur d'Alene River (NFCDR) and the South Fork Coeur d'Alene River (SFCDR). The CDR watershed stretches from the Idaho-Montana border in the east to Coeur d'Alene Lake near the Idaho-Washington border in the west, draining about 1,465 square miles with a mean watershed elevation of 3,730 feet. Most of the CDR watershed is forest with steep, narrow valleys. The Spokane River flows west from the outlet of Coeur d'Alene Lake. The other major tributary to Coeur d'Alene Lake is the St. Joe River, which is unaffected by mining, has one major branch (St. Maries River), and drains about 1,730 square miles with a mean watershed elevation of 4,070 feet. Most of the St. Joe River watershed is steep forest, similar to the CDR watershed (U.S. Geological Survey, 2016c).

The Coeur d'Alene mining district is primarily within the SFCDR watershed but also includes parts of the NFCDR watershed (Long, 1998). Mineralization in the district occurs in veins hosted in metasedimentary rocks of the Proterozoic Belt Supergroup, with galena, sphalerite, and tetrahedrite being among the most important ore-bearing minerals. Ore deposits occur in a strongly folded and faulted shear zone and are offset by two major strike-slip faults-the Osburn and Placer Creek faults (Fryklund and Weis, 1964).

Remedial actions in the non-populated portions of the Bunker Hill Superfund Site began in 1992 and have been varied and extensive throughout the SFCDR, main-stem CDR, and in SFCDR tributaries including Canyon, Ninemile, and Pine Creeks. While most actions have been completed by the EPA, other entities such as the Bureau of Land Management and mine owners have also conducted some cleanup activities, particularly in Canyon Creek and Pine Creek. Actions from 1992 to present (2020) have included hillside excavation, terracing, and revegetation; the capping and covering of the Central Impoundment Area; removal, stabilization or capping of tailings from streambanks and land surfaces; upgrades to the Central Treatment Plant; water treatment pilot projects; and the demolition of mine and mill structures (U.S. Environmental Protection Agency, 2012a)

\footnotetext{
${ }^{1}$ A water year starts October 1 of the previous calendar year and ends September 30 .
} 


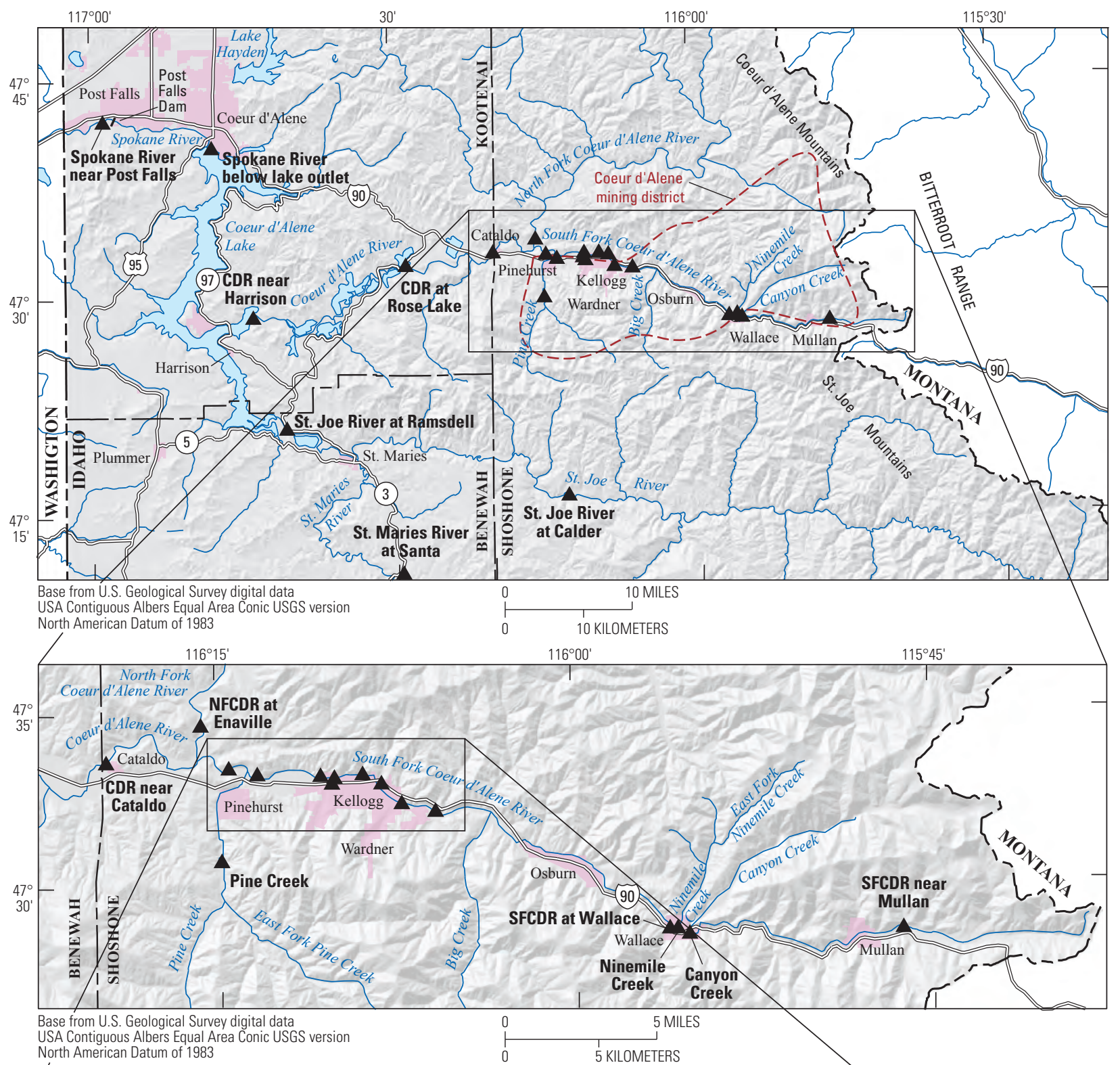
North American Datum of 1983

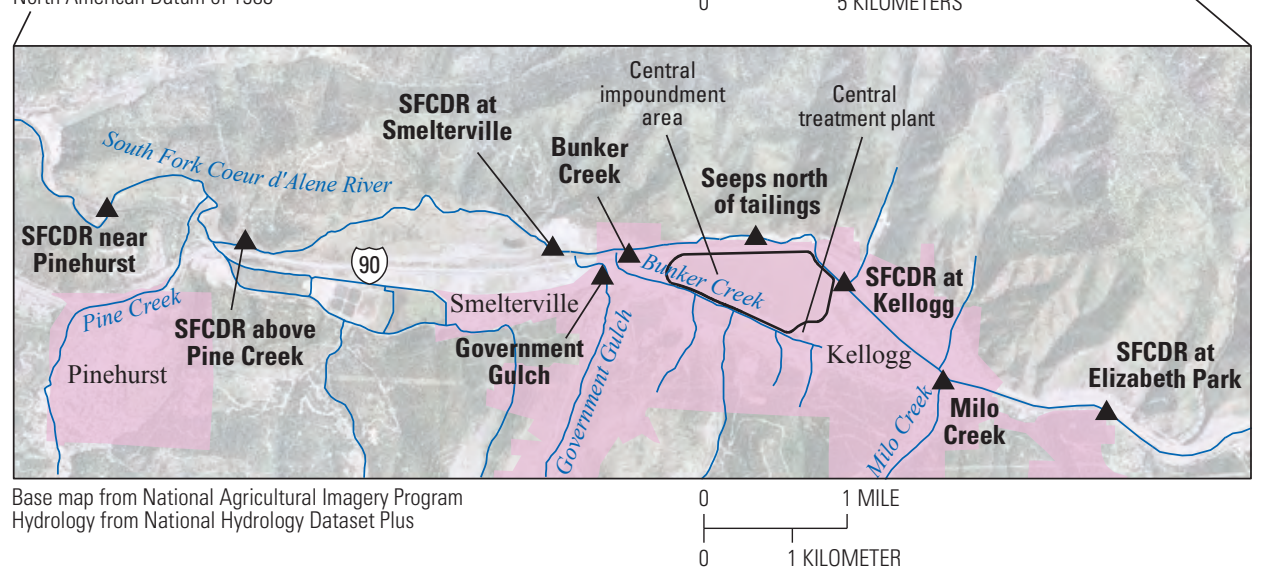

EXPLANATION

$\triangle$ Monitoring site and site name City limits

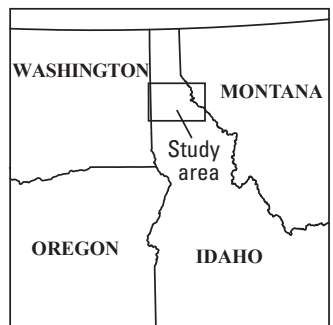

Figure 1. Study area and sampling sites, Spokane River watershed, northern Idaho. The Bunker Hill Superfund Site comprises locations within the watershed where mining-related contamination is located. CDR, Coeur d'Alene River; NFCDR, North Fork Coeur d'Alene River; SFCDR, South Fork Coeur d'Alene River. 


\section{Constituent Transport}

Previous works have established the major patterns of streamflow and metal and nutrient concentrations, loads, and transport in the study area. Loads represent the total mass (measured in kilograms or metric tons) of a constituent conveyed through a point over an interval of time (per day or per year). Both concentrations and loads are important for understanding trends in the study area. Constituent concentrations directly affect aquatic organisms and can be compared to water-quality criteria and some remedial action benchmarks to assess long-term changes. Loads are helpful for understanding the sources and delivery timing of constituents and for understanding the total mass of constituents moving downstream and entering Coeur d'Alene Lake. The CDR and St. Joe River contribute roughly similar amounts of streamflow and total phosphorus loads to Coeur d'Alene Lake (Maupin and Weakland, 2009; Clark and Mebane, 2014), but the CDR is the source of virtually all metals (Clark, 2003; Clark and Mebane, 2014). Within the CDR, the NFCDR contributes roughly 70 percent of total streamflow (versus 30 percent from the SFCDR), while the SFCDR contributes over 90 percent of the total cadmium, zinc, and lead load, as measured in the CDR near the confluence of the NFCDR and SFCDR (Clark, 2003; Donato, 2006; Clark and Mebane, 2014). However, while the SFCDR is the source of most of the cadmium and zinc load in the CDR, most of the lead load comes from the main-stem CDR between the confluence near Cataldo and the outlet near Harrison (Clark, 2003; Clark and Mebane, 2014). Although the biggest loads of zinc, cadmium, and lead are transported during high streamflow events, the highest concentrations of zinc and cadmium (which occur primarily in the dissolved form) occur during low streamflow conditions in both the SFCDR and main-stem CDR (Clark, 2003; Clark and Mebane, 2014). Lead occurs primarily in the particulate form, and high streamflow events (particularly rain-on-snow winter flood events) have historically transported both the highest concentrations and loads of lead (Beckwith, 1996; Clark and Mebane, 2014). Similar to total lead, the highest concentrations and loads of total phosphorus occur during flood and runoff events (Idaho Department of Environmental Quality and Coeur d'Alene Tribe, 2019). Particulate zinc and cadmium also become a more important part of the total zinc and cadmium loads in the SFCDR and CDR during high streamflow events (Clark and Mebane, 2014).

\section{Approaches for Load Calculation and Trend Detection}

Multiple previous works have used the LOAD ESTimator (LOADEST) software package (U.S. Geological Survey, 2016b) to estimate metal and nutrient loads and concentrations in the study area over 5-10 year intervals (Clark, 2003; Donato, 2006; Wood and Beckwith, 2008; Clark and Mebane, 2014). The LOADEST model uses maximum likelihood regression to develop regression relationships between concentration, discharge, time, and season (Runkel and others, 2004). The sign and significance of the coefficients associated with time can be interpreted as representing change in concentration in a stream over time (Donato, 2006), but the LOADEST model fundamentally relies on the assumption that the shape of the underlying relationships (for example, between concentration and discharge) remains constant over time. This assumption becomes problematic for long-term analyses where the relationship between concentration and the predictor variables can change. For example, this issue could be particularly important where remedial measures might have had a profound effect on concentrations during high flow events but little effect at low flow (or vice-versa). The LOADEST model is not able to capture such differences and the failure to do so can confound interpretations of the changes taking place.

The recent development of the Weighted Regressions on Time, Discharge and Season (WRTDS) modeling approach and subsequent enhancements have sought to address some of the limitations of conventional load models such as LOADEST (Hirsch and others, 2010). Fundamentally a weighted regression model, WRTDS develops a time-varying linear relationship between log-transformed concentrations and explanatory variables (time, discharge, and season) by creating a unique regression between the variables for each day in the period of study. Thus, WRTDS is a highly flexible model that allows the relationships between concentration, discharge, and season to change gradually over time (Hirsch and others, 2010). The resulting model can then be used to explore trends in flow-normalized concentrations and loads over various time periods, such as years, seasons, or months (Sprague and others, 2011). Flow-normalization is an important component of the method because it removes the influence of year-to-year variation in streamflow. This greatly enhances the ability of the method to identify trends (by increasing the signal to noise ratio) and protects the analysis from being highly influenced by the random occurrence of a particularly wet or dry year near the end or the beginning of the period of study (Sprague and others, 2011). The WRTDS model is implemented by using the Exploration and Graphics for RivEr Trends (EGRET) package (Hirsch and De Cicco, 2015) for R (R Core Team, 2019).

The initial implementation of WRTDS relied on the assumption that, although the relationship between discharge and concentration may change, the underlying distribution of discharges remained stationary (Hirsch and others, 2010). While this is often a reasonable assumption over short time periods, it can break down over longer periods of trend analysis when land use changes or climate impacts influence patterns of discharge. A recently developed extension of the EGRET package created a series of tools to evaluate trends in discharge over the period of interest (Hirsch, 2018) and developed a method to partition the impact of changes in discharge versus the importance of other explanatory variables in contributing to an observed trend in concentration or load (Choquette and others, 2019). 
Other subsequent works related to WRTDS have created tools to describe biases in WRTDS load and concentration estimates (Hirsch, 2014); developed a method to estimate uncertainty associated with trends from WRTDS (Hirsch and others, 2015); and implemented Kalman filtering within WRTDS (Zhang and Hirsch, 2019). The Kalman filtering enhancement uses actual sample concentrations in place of estimates for days in the study period with water-quality samples. This generally has the net effect of improving the accuracy of load and concentration estimates for specific days, seasons, or years (Lee and others, 2019; Zhang and Hirsch, 2019). Accordingly, a new extension of WRTDS, WRTDS_K, was created to implement the Kalman filtering (Hirsch, 2019).

Recent publications have compared the performance of conventional load estimation methods (including LOADEST) to the newer WRTDS and WRDTS_K methods (Hirsch, 2014; Lee and others, 2016; Lee and others, 2017; Lee and others, 2019). Each load estimation method is capable of producing accurate load and concentration estimates (Lee and others, 2016; Lee and others, 2019), but WRTDS_K is generally most likely to produce the most accurate estimates (Lee and others, 2019). Previous studies in the study area have determined that, over the time period considered in this report (approximately $15-30$ years), multiple constituents show substantial trends, and constituents have complicated relationships to streamflow (Clark and Mebane, 2014). Given these challenges and the results of recent method comparisons, WRTDS and WRTDS_K models were selected for this study. Specifically, WRTDS was used to estimate flow-normalized annual mean concentrations and annual total loads and to explore and describe trends because the flow-normalized estimates increase the signal-to-noise ratio by removing variation due to differences in streamflow. In contrast, WRTDS_K was used to make the best estimates of annual mean concentrations and annual total loads because these models more fully utilize the available sample information.

\section{Methods}

\section{Data Collection}

The USGS has been collecting water-quality and streamflow data in the study area under various programs with different cooperators for several decades. Relatively consistent water-quality sample collection and continuous streamgaging at several sites in the study area began in WY 1990. Analysis of long-term datasets are powerful for analyzing trends, but compiling and checking such datasets can be challenging because of inevitable changes in sample collection procedures and sampling strategies, lab analysis techniques, precision and accuracy, data management, and more. Impacts of such changes that are pertinent to this study are explored in the "Water-Quality Data" and "Quality Control Samples" sections. Table 1 summarizes the USGS sites used in various analyses in this report, including which type of data were used from each site, noting where site data were combined to yield longer records and describing the abbreviated site names used hereinafter. This report uses "site" to refer to water-quality sampling locations and continuous streamgaging locations. Note that "streamflow," "discharge," and "flow" have equivalent meaning in this report, but "discharge" is only used when referring to eponymous statistical or gaging techniques, and "flow" is only used when referring to flow-normalized results.

\section{Streamflow Data}

The USGS has operated continuous streamgages in the study area over a variety of timescales, with some streamgaging sites dating back to 1911 (NFCDR at Enaville) and others installed as recently as 2014 (Spokane River below Blackwell near Coeur d'Alene). Gage records also differ in continuity because operations were not necessarily continuous for each gage and there are record gaps of various lengths at some sites. Streamgaging sites on the SFCDR, NFCDR, tributaries, and the CDR near Cataldo use conventional stage-discharge relationships to estimate continuous streamflow (Sauer and Turnipseed, 2010; Turnipseed and Sauer, 2010). Streamgaging sites for the CDR near Harrison, the St. Joe River at Ramsdell, and the Spokane River below lake outlet are affected by backwater conditions for part of the year due to the operation of a hydroelectric dam on the Spokane River downstream of Coeur d'Alene Lake. These gaging sites use index velocity methods to estimate continuous streamflow (Levesque and Oberg, 2012).

In 2002, the USGS formally adopted the use of acoustic Doppler velocity meters (ADVMs) to produce continuous streamflow records (Morlock and others, 2002). ADVMs measure stream velocity in two dimensions and use those measurements along with an index velocity relationship to estimate streamflow (Levesque and Oberg, 2012). This method can be particularly useful in channels that are prone to backwatering effects where traditional stage-discharge relationships often break down (Morlock and others, 2002; Levesque and Oberg, 2012). Following the widespread implementation of this technique, the USGS installed three ADVM continuous gage systems in the study area in the early 2000s: one in the CDR near Harrison, one in the St. Joe River at Ramsdell, and one in the Spokane River below lake outlet. Each of these locations is prone to backwater effects; thus, the installation of these ADVM gages marks the first time that continuous stream gage records were available for these locations. 


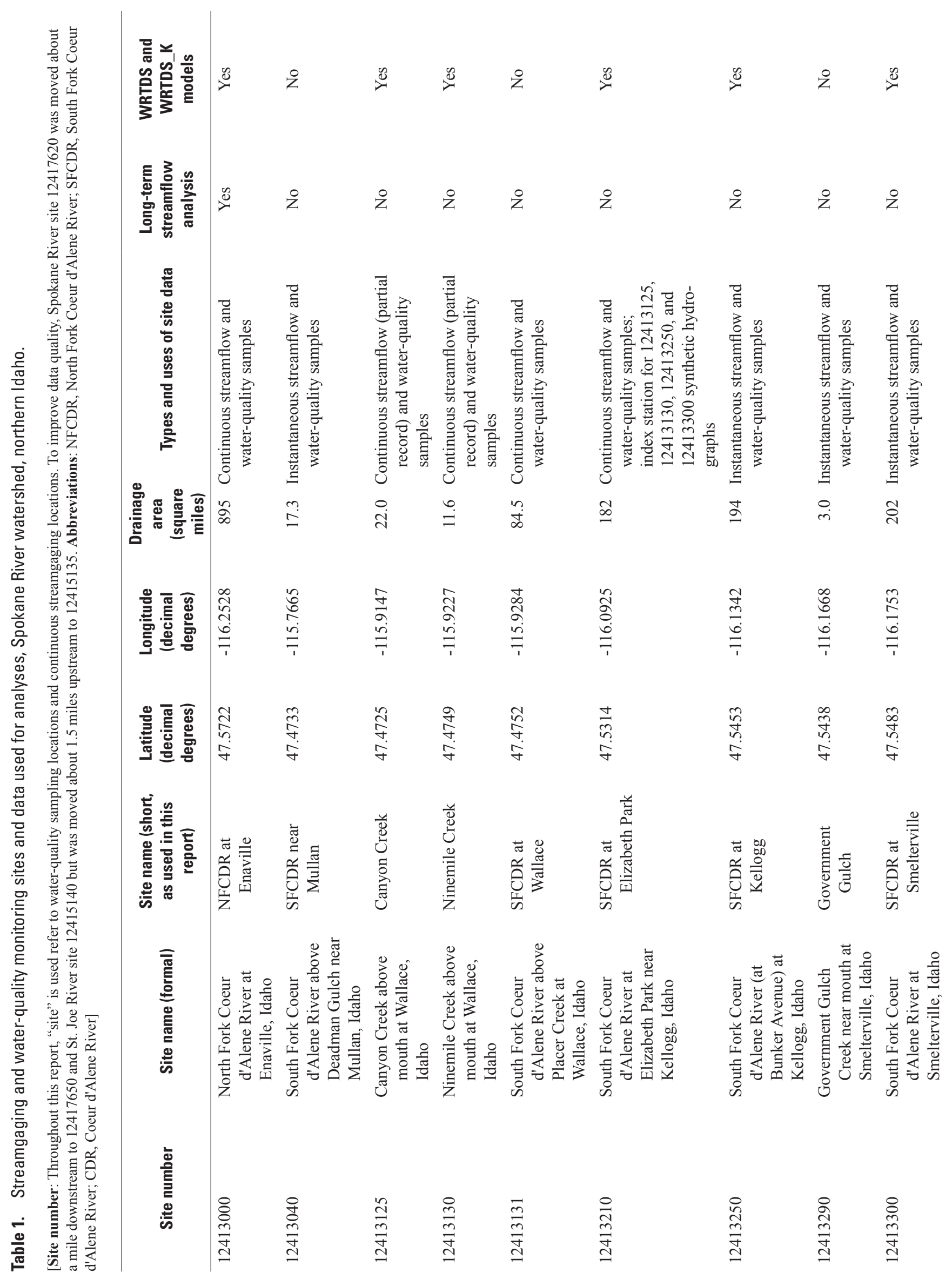




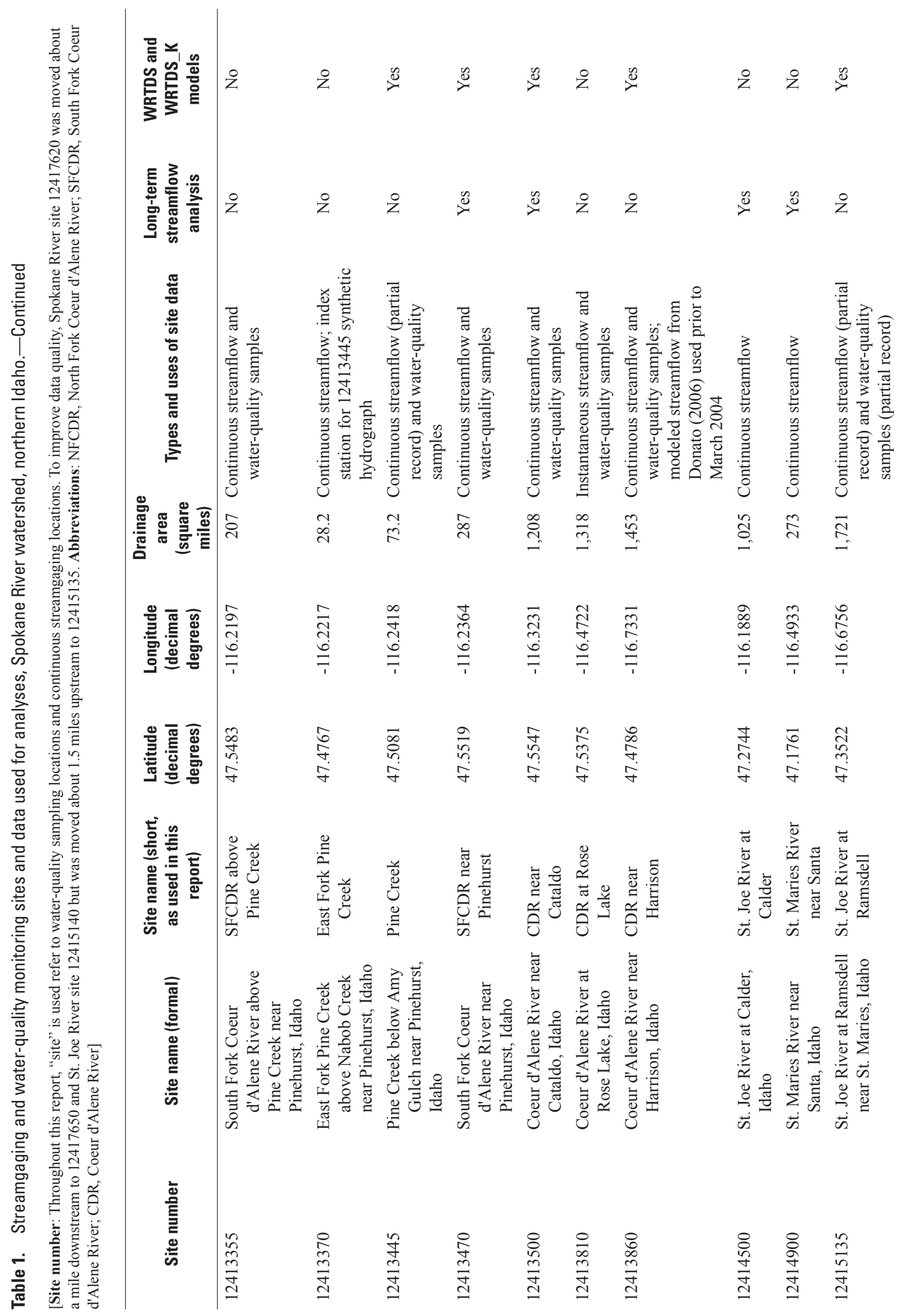




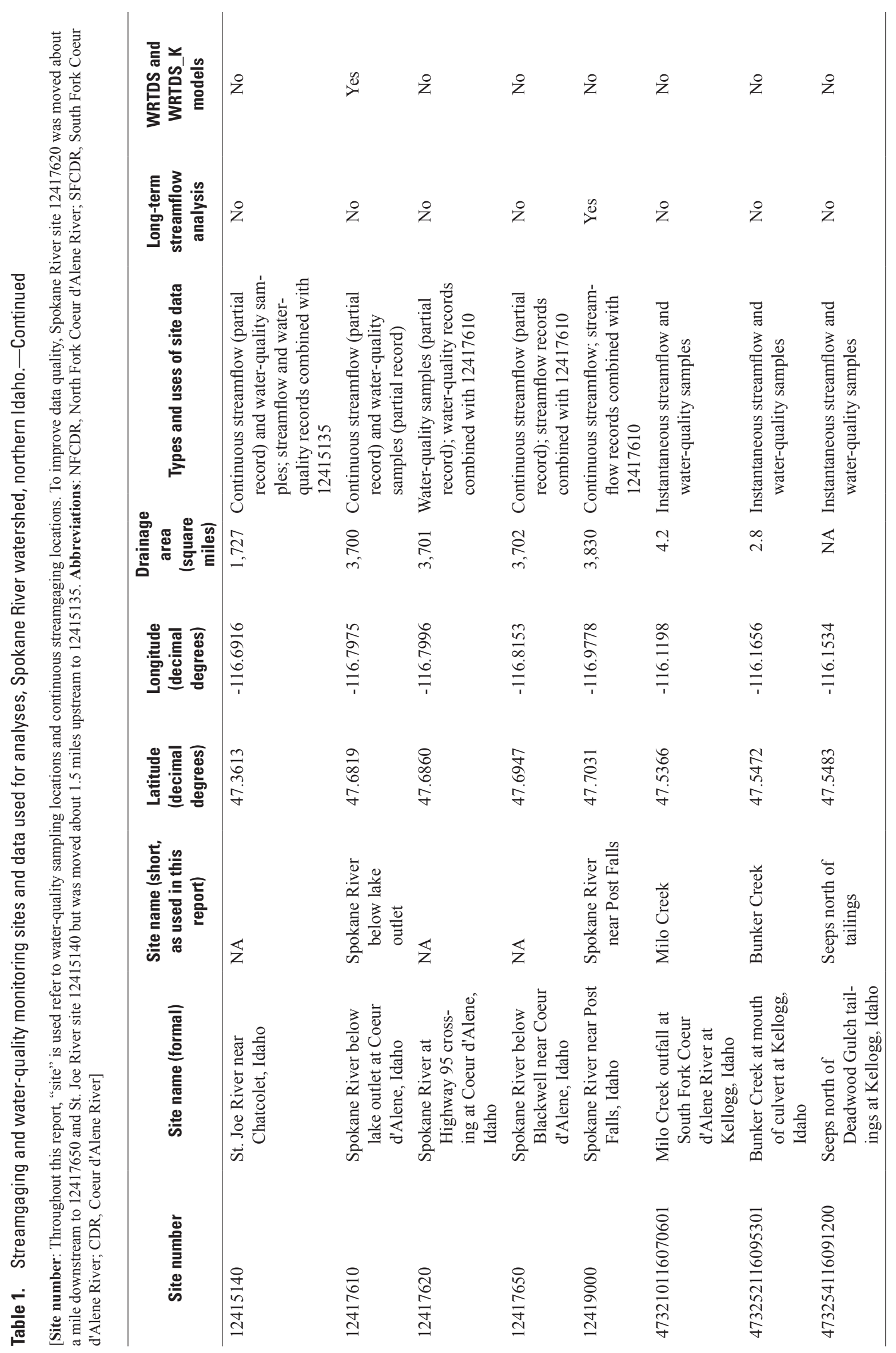




\section{Trends in Trace Metals and Nutrients in the Coeur d'Alene River Basin}

These locations have nonetheless been challenging. As table 1 shows, the original Spokane River ADVM streamgaging site was at 12417620 , but it was moved about a mile downstream to 12417650 to improve the data quality. Similarly, the original St. Joe River gaging site was at 12415140, but it was moved about 1.5 miles upstream to 12415135 to improve data quality. In both cases, the streamflow records from both sites on each river have been combined for the analyses in this report to generate a longer streamflow record.

At sites without continuous stream gages, measurements or estimates of streamflow have generally been made at the time of water-quality sample collection. Measurement of streamflow followed standard USGS procedures (Rantz, 1982; Oberg and others, 2005; Mueller and others, 2013). During some flooding and runoff events, it was more important to collect as many water-quality samples as close in time as possible to capture specific hydrologic and transport conditions than to take synchronous streamflow measurements. For these events, streamflow at sites without gaging sites was sometimes estimated after the fact based on the relationship between the ungaged site and a proximal, continuously gaged site. These streamflow records are marked with an "E" for "estimated" in the National Water Information System (U.S. Geological Survey, 2020).

For many water-quality analyses, including loading estimates, it is imperative to have continuous, daily streamflow records to pair with water-quality samples. However, this requirement presents a significant challenge in the study area where backwater conditions and technology limited gaging ability prior to the early 2000s at some critical sites (that is, CDR near Harrison, the St. Joe River at Ramsdell, and the Spokane River below lake outlet), at gaging sites that have been intermittently operated (that is, Pine, Ninemile, and Canyon Creeks), and at some important, long-term water-quality sites that have simply not had continuous gages (SFCDR at Kellogg and SFCDR at Smelterville). Depending on the site, different solutions were employed to create or extend streamflow records (table 1). In the St. Joe River at Ramsdell, the length of the gaging record simply limited the timespan available for water-quality analysis, and long-term streamflow analysis was completed using two upstream gages (St. Joe River at Calder and St. Maries River near Santa). In the Spokane River, a downstream gage (12419000) was directly used for long-term streamflow analysis and for extension of the continuous streamflow record of water-quality loading and trend analysis; this approach is consistent with previous loading analyses (Donato, 2006). For the CDR near Harrison, this report used a previously generated daily streamflow record for WYs 1991-2004. The record was developed using the USGS streamflow model FourPt (Donato, 2006). The FourPt model uses channel geometry and water-stage data at upstream (CDR near Cataldo) and downstream (lake stage at the Coeur d'Alene Lake outlet) sites to produce streamflows (Donato, 2006).
Finally, synthetic hydrographs were generated for some sites that had gaps in their records (Ninemile and Canyon Creeks), where streamgaging was discontinued but waterquality sample collection was not (Pine Creek), or where there was no gage but there was long-term water-quality sampling (SFCDR at Kellogg and SFCDR at Smelterville). In each case, the synthetic hydrograph was generated for the minimum amount of time necessary (for example, just for the record gap). Synthetic hydrographs use the relationship between daily streamflow at a continuous site and either daily streamflow or miscellaneous streamflow measurements (or estimates as described earlier) at a site with partial records or no gage, respectively, to generate a continuous streamflow record at the ungaged site (Hirsch, 1982; Nielsen, 1999; Granato, 2009). The MOVE. 1 regression technique was used on logtransformed data, with the Duan smoothing method to biascorrect the transformed synthetic hydrograph data (Granato, 2009). The MOVE. 1 technique was used to remedy the problem that the extended parts of streamflow records will have a loss of variance compared to a real record. The MOVE. 1 compensates for this loss of variance. For Ninemile and Canyon Creeks, the nearest downstream site (SFCDR at Elizabeth Park) was used to generate the synthetic hydrographs. For the SFCDR at Kellogg and Smelterville, the nearest upstream continuous streamgaging site (SFCDR at Elizabeth Park) was used to generate the synthetic hydrographs. This is the closest, most reliable, and longest operating continuous streamgage for each of these sites. For Pine Creek, the nearest upstream site (East Fork Pine Creek) was used to generate the synthetic hydrograph (table 1).

\section{Water-Quality Data for Water Years 1990-2003}

A synopsis of data collected under various programs and cooperators in the 1990s is provided in Beckwith (1998). Specific methods for data collected in calendar years 1991-92 are documented in Woods and Beckwith (1997); these data were collected as part of an effort to evaluate Coeur d'Alene Lake, including its nutrient and trace metal balances. Specific methods for data collected in WYs 1993-94 are documented in Beckwith and others (1997); these data were associated with a Natural Resources Damage Assessment. Data collection was coordinated with the EPA for the Remedial Investigation/ Feasibility Study beginning in WY 1996 (Beckwith, 1998). Additional data were collected under a separate but temporally and geographically overlapping USGS national water-quality program from WY 1997 to 2001 (Clark, 2003).

As described by Donato (2006), these studies differed in objectives, and, therefore, the number of samples collected and constituents analyzed also varied. Nonetheless, the studies similarly sought to collect samples over a range of hydrological conditions, and all samples were collected and analyzed by USGS personnel under standard, published methods that were current at the time of collection. Width and depth-integrated sampling procedures were used to collect samples pre-2004 (Edwards and Glysson, 1988; Edwards and Glysson, 1999) 
except for during some extreme floods (Beckwith, 1996) and under some low-streamflow, backwatered conditions in the CDR when velocities were insufficient to use isokinetic samplers (Beckwith and others, 1997). Samples were composited, filtered, and preserved as appropriate and shipped to the USGS National Water-Quality Laboratory (Colorado) for analysis. Analytical and quality control and quality assurance procedures for this time period are documented in Fishman (1993) and Pritt and Raese (1995), respectively.

One especially consequential change in sample collection and equipment cleaning procedures was implemented in WY 1994. Following a period of extensive testing, the USGS adopted parts per billion sampling and equipment cleaning protocols effective at the start of WY 1994 (U.S. Geological Survey, 1993). Water-quality samples with low levels of trace metals collected prior to this date have an unquantifiable risk of contamination; as such, data collected before this date at low concentrations should be reviewed carefully for inclusion in analyses (U.S. Geological Survey, 1992). The impact of this change on data quality and the data used for analyses hereinafter is discussed in the "Quality Control Samples" section.

\section{Water-Quality Data for Water Years 2004-18}

The surface water Basin Environmental Monitoring Program was implemented in WY 2004 and is ongoing as of 2020; analyses for this report include data through WY 2018. Even within the program, sampling locations and frequencies have changed over time as described by Clark and Mebane (2014); during WYs 2009-18, up to 20 sites were sampled consistently multiple times per year. As with the older data, samples were taken over a range of hydrological conditions, were collected with width- and depth-integrating equipment and were then composited and subsampled (U.S. Geological Survey, variously dated). Samples for whole-water recoverable analyses (hereinafter referred to as "total") were preserved as appropriate; samples for "dissolved" analyses were pumped through a 0.45 micrometer filter, then preserved as appropriate (U.S. Geological Survey, variously dated). Samples were shipped to the USGS Cascades Volcanic Observatory Laboratory (Washington State) for suspended sediment concentration and sand break analyses and sent to the USGS National Water-Quality Laboratory (Colorado) for all other analyses, including nutrients, trace metals, major cations, and anions (Garbarino and others, 2006).

\section{Analyses}

The goal of this report is to describe trends in concentrations and loads in the Spokane River watershed resulting from remedial activities. The drastically different lengths of water-quality records, and the fact that some important water-quality monitoring sites do not have associated gaging sites, necessitated the use of different approaches for analysis. Thus, streamflow trends were explored at a limited number of key gaging sites (6) in the study area. Because concentration data, but not necessarily continuous streamflow, were readily available for each of the WYs 2009-18 water-quality monitoring sites (20), ambient water-quality criteria (AWQC) ratios were used to describe change in concentrations throughout study area. For sites with 13-29 years of water-quality records and concurrent daily streamflow (12), annual mean concentrations and annual total loads and flow-normalized annual mean concentrations and annual total loads were estimated, and concentration and load trends analyses were completed. These analysis methods are described in greater detail below.

\section{Ambient Water-Quality Criteria}

For the constituents of concern, the water-quality criteria that are most broadly relevant across the study area for surface water are the AWQC. As used here, "AWQC" refers to the chronic criteria for aquatic life and vary across the study area. For surface waters in the SFCDR watershed (including tributaries), there are SFCDR-specific criteria defined in the Idaho Code. For all other waters in the study area (NFCDR, main-stem CDR, St. Joe River at Ramsdelland, Spokane River below lake outlets), the statewide Idaho criteria apply (Idaho Department of Environmental Quality, variously dated). Both the statewide and SFCDR-specific criteria for lead, zinc, and cadmium are expressed as equations that are hardnessdependent and thus vary by site and even by sampling event, as hardness typically varies with streamflow. As an example, a selection of AWQC under SFCDR and state-wide criteria for different hardnesses is shown in table 2.

In practice, accurate comparison to the regulatory criteria required that a unique $\mathrm{AWQC}$ was calculated for each site for each sampling event according to the criteria equations given in the Idaho Code (Idaho Department of Environmental Quality, variously dated). Thus, for the purpose of comparing site concentrations to AWQC across the study area, this report uses AWQC ratios. That is, the constituent concentration at each site during each sampling event was divided by the site- and event-specific AWQC to produce an AWQC ratio. An AWQC ratio greater than 1.0 indicates criteria exceedance, and an AWQC ratio less than or equal to 1.0 indicates that the water meets criteria. This convention is not unique to this report; it was also used by Clark and Mebane (2014) and throughout various Records of Decision (U.S. Environmental Protection Agency, 2002; 2012b), including for the purpose of defining some remedial action targets. The use of the word "exceedance" in the present report is as it is used in the Records of Decision-to evaluate remediation effectiveness. This usage differs from the explicit language in the Idaho Code, which defines compliance with chronic aquatic life criteria as a three-part definition such that the criteria concentration should not be exceeded for a 4-day average concentration more than once every 3 years (Idaho Department of Environmental Quality, variously dated). The sampling protocols used to collect the samples analyzed in this report did not include the collection of multiple samples within 
Table 2. Example ambient water-quality criteria for different sample hardness, South Fork Coeur d'Alene River-specific and Idaho state-wide criteria.

[Abbreviations: $\mathrm{mg} / \mathrm{L}$ as $\mathrm{CaCO}_{3}$, milligram per liter as calcium carbonate; SFCDR, South Fork Coeur d'Alene River; $\mu \mathrm{g} / \mathrm{L}$, microgram per liter.]

\begin{tabular}{ccccccc}
\hline $\begin{array}{c}\text { Hardness } \\
(\mathbf{m g} / \mathbf{L} \text { as } \\
\left.\mathbf{C a C O}_{3}\right)\end{array}$ & \multicolumn{2}{c}{ SFCDR ambient water-quality criteria } & \multicolumn{3}{c}{ Idaho statewide ambient water-quality criteria } \\
\cline { 2 - 7 } & $\begin{array}{c}\text { Dissolved cad- } \\
\mathbf{m i u m}(\boldsymbol{\mu g} / \mathbf{L})\end{array}$ & $\begin{array}{c}\text { Dissolved lead } \\
(\boldsymbol{\mu g} / \mathbf{L})\end{array}$ & $\begin{array}{c}\text { Dissolved zinc } \\
(\boldsymbol{\mu g} / \mathbf{L})\end{array}$ & $\begin{array}{c}\text { Dissolved cad- } \\
\mathbf{m i u m}(\boldsymbol{\mu g} / \mathbf{L})\end{array}$ & $\begin{array}{c}\text { Dissolved lead } \\
(\boldsymbol{\mu g} / \mathbf{L})\end{array}$ & $\begin{array}{c}\text { Dissolved zinc } \\
(\boldsymbol{\mu g} / \mathbf{L})\end{array}$ \\
\hline 10 & 0.19 & 3.3 & 42 & 0.15 & 0.54 & 37 \\
25 & 0.37 & 7.7 & 78 & 0.25 & 0.54 & 37 \\
35 & 0.47 & 11 & 97 & 0.31 & 0.79 & 49 \\
50 & 0.62 & 15 & 123 & 0.38 & 1.2 & 66 \\
100 & 1.0 & 28 & 195 & 0.57 & 2.5 & 118 \\
\hline
\end{tabular}

4-day periods at each site to meet the letter of the Idaho Code, which would have been logistically and financially infeasible. Instead, as chronic criteria concentrations are intended to protect aquatic communities from continuous exposure to chemicals, the chronic concentration values are simply considered the most appropriate benchmark for evaluating remedial progress.

\section{Streamflow Trends}

The WRTDS method relies on daily discharge to estimate daily concentrations and loads. While the original model allows the relationship between discharge and concentration to be flexible over time, the underlying assumption is that the discharge distribution over the studied time period remains the same (Hirsch and others, 2010). This assumption is not always appropriate, and a WRTDS extension provides a method to accommodate discharge changes over the period of record (Hirsch and DeCicco, 2018; Choquette and others, 2019). Thus, before beginning the WRTDS analysis, six key continuous gaging sites in the study area (SFCDR near Pinehurst, NFCDR at Enaville, CDR near Cataldo, St. Joe River at Calder, St. Maries River at Santa, and Spokane River near Post Falls) were analyzed for trends in streamflow from WY 1990 to 2018. The flowTrends R code, an extension of the EGRET package, was used to evaluate trends (Hirsch, 2018). Basic statistics such as daily discharge minimum, maximum, and median were compiled, and the non-parametric MannKendall trend test with Theil-Sen slope (Helsel and Hirsch, 2002) was conducted to determine if there were statistically significant changes in any of these metrics over the 29-year period considered. The Mann-Kendall test determines whether a trend in discharge is statistically significant over time and is robust for non-normal data and against outliers, both of which are common in hydrologic data. The Theil-Sen slope provides an estimate of the direction and magnitude of the Mann-Kendall trend (Helsel and others, 2020). Additionally, the flowTrends code was used to create a visualization (called the Quantile-Kendall plot) of the Mann-Kendall trend test with Theil-Sen slope for each daily discharge statistic, starting with the minimum and moving to the second lowest daily discharge, the third lowest daily discharge, and so on through the maximum (Hirsch, 2018; Choquette and others, 2019).

\section{Water Quality: Concentrations, Loads, and Trends}

As described in the "Introduction" section, this report uses the WRTDS model and various extensions to describe concentrations and loads and trends in both over time. Specifically, WRTDS was used to estimate annual flownormalized concentrations and loads, whereas WRTDS_K was used to estimate annual mean concentrations and loads. The basic form of the underlying WRTDS model is:

$$
\begin{aligned}
& \ln (c)=\beta_{0}+\beta_{1} t+\beta_{2} \ln (Q)+ \\
& \beta_{3} \sin (2 \pi t)+\beta_{4} \cos (2 \pi t)+\varepsilon
\end{aligned}
$$

where

$$
\begin{aligned}
c & \text { is concentration; } \\
Q & \text { is discharge; } \\
t & \text { is time in years; and } \\
\varepsilon & \text { is unexplained variation. }
\end{aligned}
$$

The equation is essentially a weighted regression model, and functionally is fit in the form of weighted Tobit model (also known as a "survival regression"). This form accommodates censored data because each concentration value can be expressed as a single number for uncensored data or as an interval (that is, between 0 and 0.5 ) in the case of censored data (Hirsch and others, 2015; Hirsch and De Cicco, 2015). The method is implemented in $\mathrm{R}$ ( $\mathrm{R}$ Core Team, 2019) using the EGRET package (Hirsch and De Cicco, 2015). The WRTDS_K enhancement is currently available as additional code (Hirsch, 2019).

As described previously in the "Data Collection" section, each site varies somewhat in the length of record, number of samples, and constituents available. Overall, 12 sites had enough data to implement the WRTDS modeling (Ninemile Creek; Canyon Creek; Pine Creek; SFCDR at Elizabeth Park, 
at Kellogg, at Smelterville and near Pinehurst; NFCDR at Enaville; CDR near Cataldo and near Harrison; St. Joe River at Ramsdell; and Spokane River below lake outlet). Nine parameters (total and dissolved zinc, cadmium, and lead; total phosphorus and nitrogen; and orthophosphate) were considered, though not all parameters were modeled for all sites. Table 3 summarizes the sites, parameters, start and end dates, the number of samples (total and censored), and the flux bias statistic for each model (Hirsch, 2014). Generally, the longest records (25-29 years) were available for SFCDR near Pinehurst, CDR near Harrison, CDR near Cataldo, NFCDR at Enaville, and SFCDR at Elizabeth Park. Shorter intervals (17-23 years) were available for the tributaries and most other SFCDR sites. The shortest available records were for the SFCDR at Kellogg, the St. Joe River at Ramsdell and the Spokane River below lake outlet (13-16 years).

To develop a specific WRTDS model, each parameter at each site needed to have at least 60 samples, with a minimum of 40 uncensored results at this minimum threshold. Most sites and parameters had at least 100 samples, with 50 percent or more uncensored results. WRTDS models were developed for most metals at most sites, but nutrient models were generally limited to shorter time periods and downstream sites which had fewer censored values (table 3 ).

For each model, the flux bias statistic was computed from the results. Essentially, this statistic compares the difference between the sum of the estimated fluxes (that is, loads) on the sampled days to the sum of the true (sampled) fluxes on the sampled days (Sprague and others, 2011; Hirsch, 2014). The flux bias is calculated as:

$$
\text { Flux bias }=\left(\frac{\sum_{i=1}^{n} L_{p, i}-\sum_{i=1}^{n} L_{o, i}}{\sum_{l=1}^{n} L_{o, i}}\right) \times 100
$$

where

$$
\begin{aligned}
L_{p, i} & \text { is the predicted flux from WRTDS for day } i \\
L_{o, i} & \text { is the observed flux for day } i \text {; and } \\
n & \text { is the number of sampled days in the } \\
& \text { monitoring record. }
\end{aligned}
$$

Values near zero indicate an unbiased model, negative values indicate negative bias (that is, a model that underpredicts flux), and positive values indicate positive bias (that is, a model that overpredicts flux). Previous work has found that a flux bias statistic of -0.1 to 0.1 generally corresponds to true bias of approximately plus or minus 10 percent. However, the relationship between the flux bias statistic and the true bias was highly nonlinear, with statistic values near 0.6 having true bias in the range of 100-125 percent (Hirsch, 2014)

Functionally, WRTDS creates concentration and load estimates for every day within the period of study. These estimates are then averaged over the time period of interest (in this report, each water year) to produce annual means
(Hirsch and others, 2010). Additionally, the EGRET package contains a procedure to estimate flow-normalized concentrations and loads. This procedure uses the underlying discharge data for each day (that is, September 1) to create a probability density function of discharge values. Then the integral of each estimated concentration for each discharge on that day is integrated over the discharge probability density function, and so on for every day of the study period. This function is described:

$$
E\left[C_{f n}(T)\right]=\int_{0}^{\infty} w(Q, T) \cdot f_{T s}(Q) d Q
$$

where

$$
\begin{aligned}
& \text { function of } Q \text { (discharge) and } T \text { (time, in } \\
& \text { years); and } \\
& f_{T S}(Q) \quad \text { is the probability density function of } \\
& \text { discharge, specific to a particular time of } \\
& \text { year, designated as } T_{S} \text {. }
\end{aligned}
$$$$
w(Q, T) \quad \text { is the WRTDS estimate of concentration as a }
$$

Functionally, the flow-normalized concentrations for a particular day of a particular year was based on the relationship of concentration to discharge for that day of that year and on the probability distribution of discharge for that day of the year (using the flow record from all years) (Hirsch and others, 2010; Hirsch and De Cicco, 2015). Similarly, the flow-normalized load used this same relationship of concentration to discharge, but the concentrations were multiplied by discharge to represent load.

The flow-normalized concentrations and loads were then used to calculate trends for net change for the full period of record (which varies by site and constituent) and for change from WY 2009 to 2018. These calculations are relatively simple:

$$
\begin{gathered}
\text { Net change }=c-c \\
\text { Net change in percent }=\left(\frac{c_{t 2}-c_{t 1}}{c_{t 1}}\right) \times 100
\end{gathered}
$$

where

$$
\begin{gathered}
c_{t 1} \text { is the annual mean flow-normalized } \\
\text { concentration in year } t_{1} \text {; and } \\
c_{t 2} \text { is the annual mean flow-normalized } \\
\text { concentration in year } t_{2} .
\end{gathered}
$$

These calculations were originally described in Sprague and others (2011). Trends for loads are computed in the same way, simply using the flow-normalized annual mean load in place of the flow-normalized annual mean concentrations. 
Table 3. Summary of site, parameters, water years, and samples used for Weighted Regressions on Time, Discharge and Season (WRTDS) and WRTDS with Kalman filtering (WRTDS_K) models, and flux bias statistics for WRTDS models, water years 1990-2018.

[Abbreviations: CDR, Coeur d'Alene River; NFCDR, North Fork Coeur d'Alene River; SFCDR, South Fork Coeur d'Alene River]

\begin{tabular}{|c|c|c|c|c|c|c|c|}
\hline \multirow{2}{*}{$\begin{array}{c}\text { Site name (short, as used in this } \\
\text { report) }\end{array}$} & \multirow{2}{*}{ Constituent } & \multicolumn{2}{|c|}{ Water year } & \multirow{2}{*}{$\begin{array}{c}\text { Number of } \\
\text { water years }\end{array}$} & \multirow{2}{*}{$\begin{array}{c}\text { Number } \\
\text { of total } \\
\text { samples }\end{array}$} & \multirow{2}{*}{$\begin{array}{l}\text { Number of } \\
\text { censored } \\
\text { samples }\end{array}$} & \multirow{2}{*}{$\begin{array}{l}\text { Flux bias } \\
\text { statistic }\end{array}$} \\
\hline & & Start & End & & & & \\
\hline NFCDR at Enaville & Dissolved cadmium & 2001 & 2018 & 18 & 113 & 52 & 0.05 \\
\hline NFCDR at Enaville & Dissolved lead & 2001 & 2018 & 18 & 106 & 15 & -0.16 \\
\hline NFCDR at Enaville & Dissolved zinc & 1997 & 2018 & 22 & 154 & 17 & -0.13 \\
\hline NFCDR at Enaville & Total cadmium & 2001 & 2018 & 18 & 114 & 56 & -0.09 \\
\hline NFCDR at Enaville & Total nitrogen & 2004 & 2018 & 15 & 80 & 32 & -0.01 \\
\hline NFCDR at Enaville & Total phosphorus & 1998 & 2018 & 21 & 157 & 39 & -0.16 \\
\hline NFCDR at Enaville & Total zinc & 1994 & 2018 & 25 & 170 & 39 & -0.05 \\
\hline Canyon Creek & Dissolved cadmium & 1999 & 2018 & 20 & 112 & 0 & -0.04 \\
\hline Canyon Creek & Total lead & 1999 & 2018 & 20 & 109 & 0 & -1.45 \\
\hline Canyon Creek & Total phosphorus & 2002 & 2018 & 17 & 75 & 27 & -0.97 \\
\hline Canyon Creek & Total zinc & 1999 & 2018 & 20 & 108 & 0 & -0.06 \\
\hline Ninemile Creek & Dissolved cadmium & 1999 & 2018 & 20 & 100 & 0 & -0.02 \\
\hline Ninemile Creek & Dissolved lead & 1999 & 2018 & 20 & 100 & 0 & -0.01 \\
\hline Ninemile Creek & Dissolved zinc & 1999 & 2018 & 20 & 100 & 0 & -0.02 \\
\hline Ninemile Creek & Total cadmium & 1999 & 2018 & 20 & 94 & 0 & -0.06 \\
\hline Ninemile Creek & Total lead & 1999 & 2018 & 20 & 95 & 0 & -0.67 \\
\hline Ninemile Creek & Total zinc & 1999 & 2018 & 20 & 93 & 0 & -0.06 \\
\hline SFCDR at Elizabeth Park & Total phosphorus & 2002 & 2018 & 17 & 87 & 22 & -0.64 \\
\hline SFCDR at Elizabeth Park & Total zinc & 1993 & 2018 & 26 & 167 & 0 & -0.15 \\
\hline SFCDR at Kellogg & Dissolved cadmium & 2006 & 2018 & 13 & 65 & 0 & 0.00 \\
\hline SFCDR at Kellogg & Dissolved lead & 2006 & 2018 & 13 & 65 & 0 & -0.27 \\
\hline SFCDR at Kellogg & Dissolved zinc & 2006 & 2018 & 13 & 65 & 0 & 0.00 \\
\hline SFCDR at Kellogg & Total cadmium & 2006 & 2018 & 13 & 65 & 0 & -0.15 \\
\hline SFCDR at Kellogg & Total lead & 2006 & 2018 & 13 & 65 & 0 & -0.51 \\
\hline SFCDR at Kellogg & Total nitrogen & 2006 & 2018 & 13 & 65 & 4 & -0.23 \\
\hline SFCDR at Kellogg & Total phosphorus & 2006 & 2018 & 13 & 65 & 19 & -0.61 \\
\hline SFCDR at Kellogg & Total zinc & 2006 & 2018 & 13 & 65 & 0 & -0.15 \\
\hline SFCDR at Smelterville & Dissolved cadmium & 2002 & 2018 & 17 & 98 & 0 & -0.01 \\
\hline SFCDR at Smelterville & Dissolved lead & 2002 & 2018 & 17 & 98 & 0 & -0.12 \\
\hline SFCDR at Smelterville & Dissolved zinc & 2002 & 2018 & 17 & 98 & 0 & -0.01 \\
\hline SFCDR at Smelterville & Total cadmium & 2002 & 2018 & 17 & 97 & 0 & -0.09 \\
\hline
\end{tabular}


Table 3. Summary of site, parameters, water years, and samples used for Weighted Regressions on Time, Discharge and Season (WRTDS) and WRTDS with Kalman filtering (WRTDS_K) models, and flux bias statistics for WRTDS models, water years 1990-2018.Continued

[Abbreviations: CDR, Coeur d'Alene River; NFCDR, North Fork Coeur d'Alene River; SFCDR, South Fork Coeur d'Alene River]

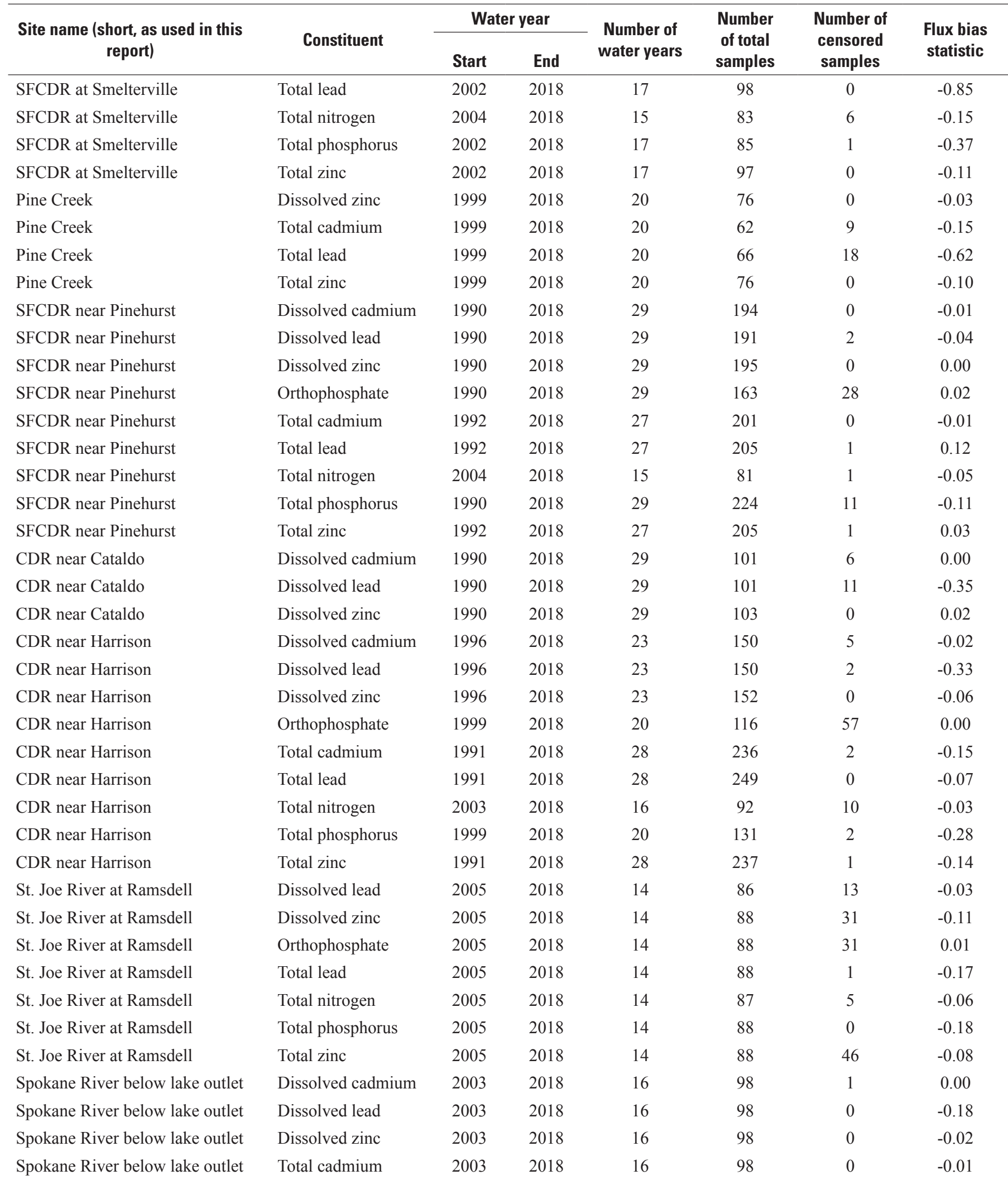


Table 3. Summary of site, parameters, water years, and samples used for Weighted Regressions on Time, Discharge and Season (WRTDS) and WRTDS with Kalman filtering (WRTDS_K) models, and flux bias statistics for WRTDS models, water years 1990-2018.Continued

[Abbreviations: CDR, Coeur d'Alene River; NFCDR, North Fork Coeur d'Alene River; SFCDR, South Fork Coeur d'Alene River]

\begin{tabular}{|c|c|c|c|c|c|c|c|}
\hline $\begin{array}{c}\text { Site name (short, as used in this } \\
\text { report) }\end{array}$ & Constituent & \multicolumn{2}{|c|}{ Water year } & $\begin{array}{c}\text { Number of } \\
\text { water years }\end{array}$ & $\begin{array}{c}\text { Number } \\
\text { of total } \\
\text { samples }\end{array}$ & $\begin{array}{c}\text { Number of } \\
\text { censored } \\
\text { samples }\end{array}$ & $\begin{array}{l}\text { Flux bias } \\
\text { statistic }\end{array}$ \\
\hline Spokane River below lake outlet & Total lead & 2003 & 2018 & 16 & 98 & 0 & -0.40 \\
\hline Spokane River below lake outlet & Total nitrogen & 2004 & 2018 & 15 & 91 & 8 & 0.01 \\
\hline Spokane River below lake outlet & Total phosphorus & 2003 & 2018 & 16 & 98 & 17 & 0.00 \\
\hline Spokane River below lake outlet & Total zinc & 2003 & 2018 & 16 & 98 & 0 & -0.01 \\
\hline
\end{tabular}

In addition to calculating trends, the EGRETci (De Cicco and others, 2019) package was used to estimate the uncertainty associated with these trends. This package uses a block bootstrapping method to construct confidence intervals around a given trend. Essentially, by randomly subsampling the dataset and recreating the WRTDS model over multiple iterations, the method calculates the trend many times (Hirsch and others, 2015). These bootstrap outcomes can be used in a variety of ways, but in this report these outcomes are summarized to describe the likelihood of the trend in common language (Hirsch and others, 2015; Oelsner and others, 2017). For example, if out of 100 bootstrap replicates, 85 or more indicated an increasing trend, then the trend has a greater than or equal to 85 percent chance of being truly up and is described as "likely up." If out of the 100 bootstrap replicates, 15 or fewer indicated an increasing trend, the trend has a greater than or equal to 85 percent chance of being truly down and is described as "likely down." This report uses the descriptor conventions established by Oelsner and others (2017) and shown in table 4 . For each model and trend interval, the minimum number of bootstrap replicates was set at 39 and the maximum number of bootstrap replicates was set at 100 to balance statistical confidence with computational demand, and the block length was set at 200 based on the sampling intervals in the underlying dataset (Hirsch and others, 2015).

Table 4. Statistical likelihood descriptors.

[Numeric range of the statistical likelihood specifically refers to the likelihood that a trend is up. Range and descriptors from Oelsner and others (2017). Symbols: $\geq$, greater than or equal to; $\leq$, less than or equal to; $<$, less than; $>$, greater than]

\begin{tabular}{cl}
\hline Range of statistical likelihood & \multicolumn{1}{c}{ Descriptor } \\
\hline 0.85 to $\leq 1.0$ & Likely up \\
$\geq 0.70$ to $<0.85$ & Somewhat likely up \\
$>0.30$ to $<0.70$ & About as likely as not \\
$>0.15$ to $\leq 0.30$ & Somewhat likely down \\
$\geq 0$ to $\leq 0.15$ & Likely down \\
\hline
\end{tabular}

The bootstrap replicate outcomes were also used to construct 90 percent confidence intervals for the trend slopes and to describe the median trend slope for select sites and constituents. Because these replicates were run for only a few models, the minimum and maximum number of replicates was set higher (500) to achieve higher statistical confidence.

\section{Results}

\section{Streamflow Stationarity}

Trends in streamflow were explored at six key gaging sites (SFCDR near Pinehurst, NFCDR at Enaville, CDR near Cataldo, St. Joe River at Calder, St. Maries River near Santa, and Spokane River near Post Falls). The latter three gaging sites differ from the sites used for water-quality analyses (table 1). For long-term streamflow analysis (WYs 1990-2018), gaging sites with complete streamflow records that were as close as possible to water-quality sites were selected. A variety of streamflow statistics (WY minimum, median, and maximum daily streamflows) were tested for significant trends over the period of record. Except for increasing minimum streamflows in the Spokane River near Post Falls, there were no significant trends in the tested statistics over the period of record. At the Spokane River near Post Falls site, this trend was likely the result of changes to hydroelectric dam operations that control streamflow at this site

The overall lack of statistical significance in streamflow trends is shown in Quantile-Kendall plots in figure 2. For each site, the results of a Mann-Kendall test with the TheilSen slope is shown for each ranked streamflow (calculated by water year). Some of the lowest streamflows in the St. Joe River at Calder modestly but significantly decreased (fig. 2d), and minimum streamflows in the Spokane River near Post Falls increased while flows in the 10th-25th percentile decreased (fig. 2f). Generally, however, across most streamflows at most sites, calculated trends were modest, ranging from -1.5 percent per year decreases to about 1.5 percent per year increases, and the vast majority of these trends were not 

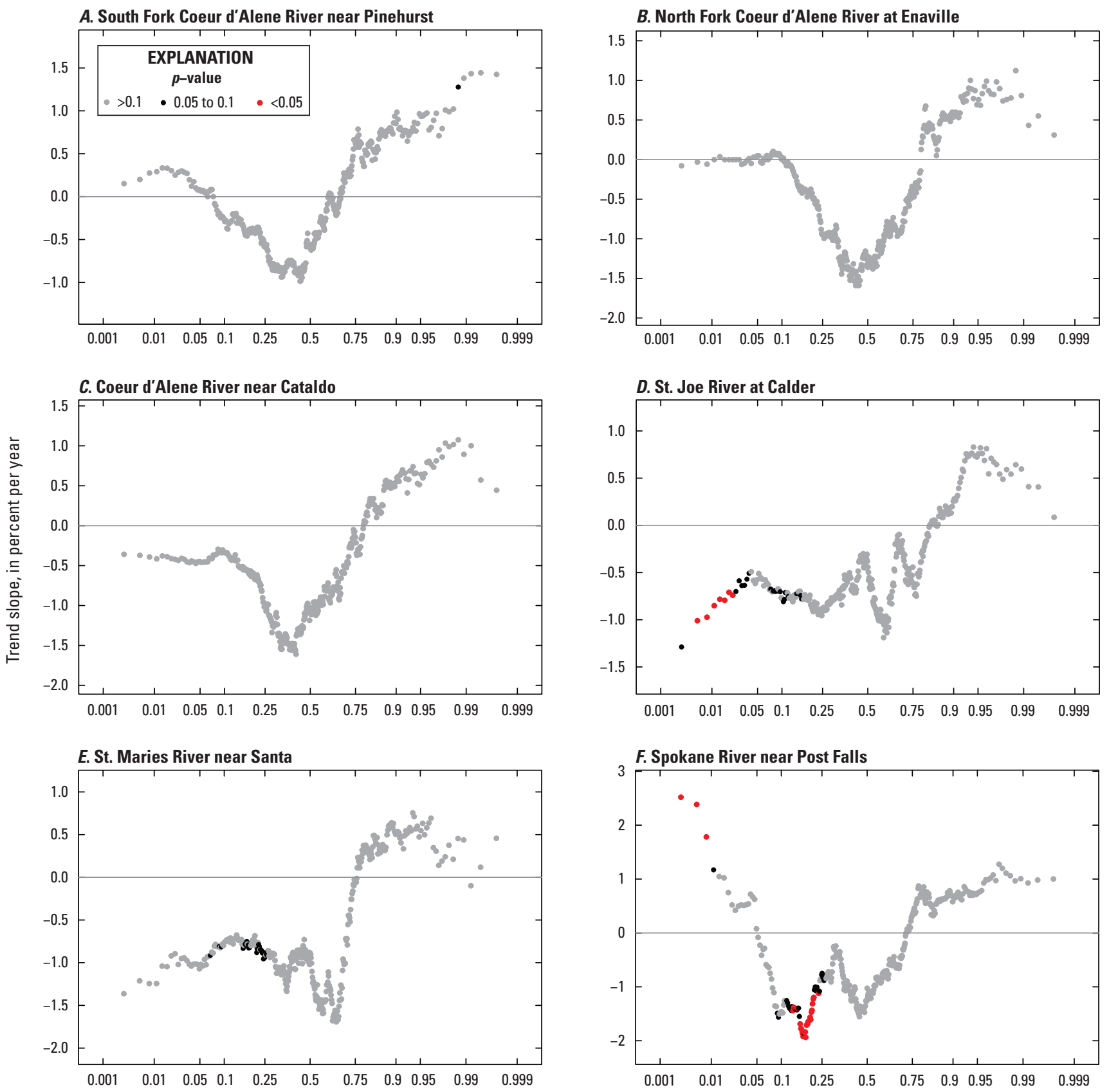

Daily non-exceedance probability

Figure 2. Quantile-Kendall plots showing trends in streamflow for water years 1990-2018 for select sites in the Spokane River watershed, northern Idaho. Trend slope represents Theil-Sen slope expressed as percent per year. Probability value ( $p$-value) represents the Mann-Kendall trend test results for each ranked streamflow. Site locations are shown in figure 1. Site descriptions are in table 1. Abbreviations: $>$, greater than; <, less than.

significant at $\mathrm{p} \leq 0.10$. One thing that all six sites had in common was that median streamflows tended to decrease with a slope of about -1.5 percent per year, but these decreases were not statistically significant. Also, the high flows (generally those above the 90th percentile) all tended to show modest increases ( $0.5-1.0$ percent per year), but they were almost never significant.
These results suggest that streamflows in the study area were reasonably stationary over the period of water-quality analysis (WYs 1990-2018). This does not imply that important changes in streamflow are not occurring in the Spokane River watershed; for example, streamflows may be changing seasonally or over longer time periods. Furthermore, there may be important changes to streamflow occurring that are not 
captured by the metrics used here. For example, this analysis did not consider the timing or duration of spring snowmelt runoff peaks, nor the frequency of rain-on-snow flooding events. However, for the purposes of this report, the lack of significant trends in most streamflows at most sites over the period of the water-quality record supported the use of WRTDS without the extension that accommodates for changing streamflows.

\section{Quality Control Samples}

For long-term trend analyses, particularly those that rely on data collected under multiple sampling programs as this report does, careful evaluation of the underlying data quality is critical for conferring confidence in the environmental reality of observed trends. Therefore, quality control samples collected from WY 1997 to 2018 were examined for each of the water-quality sites used in this report. There were no quality control samples collected, at least for the analytes considered here, from WY 1990 to 1996. Additionally, most of the blank and replicate samples were collected from WY 2009 to 2018, which was the period sampled under the most recent protocols. As discussed in the "Methods" section, USGS sampling and cleaning procedures for low-level metals changed in WY 1994. Because of this change, and the lack of pertinent QC sample data from this period to fully evaluate the impact of this change, total and dissolved metal sample results in the NFCDR at Enaville collected prior to WY 1994 were removed from this analysis because sample contamination may have caused high metals bias in samples from this period. NFDCR at Enaville was the only site with both low metals concentrations and samples collected prior to WY 1994 and was therefore the only site affected by this potential source of contamination.
From WY 1997 to 2018, 95 blank samples were collected (table 5). Detections in the blanks for nutrients (total phosphorus and nitrogen and orthophosphate) and total and dissolved cadmium were rare (0-6 detections in 66-90 samples). Detections for total and dissolved zinc were low (13-14 detections in 90-93 samples) and detected concentrations were low, particularly relative to ambient zinc concentrations in the study area (table 5).

Total and dissolved lead detections were most frequent, with 50-22 detections in 91 and 93 samples, respectively (table 5). Total lead detections occurred occasionally from WY 1997 to 2018, and the median detection (0.12 microgram per liter $[\mu \mathrm{g} / \mathrm{L}])$ was generally near the detection limit. The maximum detection $(8.53 \mu \mathrm{g} / \mathrm{L})$ was more than 4 times higher than the next highest detected concentration and was collected in WY 1999 in a blank from Canyon Creek, a site with extremely high lead concentrations (the associated sample concentration was $2,000 \mu \mathrm{g} / \mathrm{L}$ ). In an area where lead is pervasive and occurs at very high concentrations, the frequent blank detections reflect the challenge inherent in field decontamination of sampling equipment. To this end, field staff have adopted a project protocol of using only laboratory decontaminated equipment at sites with low metals concentrations (for example, SFCDR near Mullan, NFCDR at Enaville, St. Joe River at Ramsdell and Spokane River below lake outlet) to minimize total lead contamination at the most susceptible sites. Correspondingly, all blanks with total lead detections greater than $1.0 \mu \mathrm{g} / \mathrm{L}$ were associated with high concentration lead sites sampled with field decontaminated equipment, whereas blanks at low concentration lead sites either had non-detected lead or lead concentrations close to the detection limit $(0.04 \mu \mathrm{g} / \mathrm{L})$. The project protocol to manage sampling equipment has therefore successfully minimized lead contamination at the sites most susceptible to contamination bias, while the slightly higher concentration lead detections associated with field cleaned equipment were unlikely to affect data at the associated sites with much

Table 5. Summary of blank sample results, water years 1997-2018.

[Results summarized from 95 blank samples collected from October 15, 1996, to September 17, 2018. Abbreviations: mg/L, milligram per liter; NA, not applicable; $\mu \mathrm{g} / \mathrm{L}$, microgram per liter. Symbols: ; <0.004, sample concentration not detected at $0.004 \mathrm{mg} / \mathrm{L}$.]

\begin{tabular}{lccccccc}
\hline \multicolumn{1}{c}{ Constituent } & Units & $\begin{array}{c}\text { Number } \\
\text { of blank } \\
\text { samples }\end{array}$ & $\begin{array}{c}\text { Number of } \\
\text { detections }\end{array}$ & $\begin{array}{c}\text { Median concen- } \\
\text { tration of detec- } \\
\text { tions }\end{array}$ & $\begin{array}{c}\text { Maximum concen- } \\
\text { tration of detec- } \\
\text { tions }\end{array}$ & $\begin{array}{c}\text { Minimum de- } \\
\text { tection limit }\end{array}$ & $\begin{array}{c}\text { Maximum } \\
\text { detection } \\
\text { limit }\end{array}$ \\
\hline Total phosphorus & $\mathrm{mg} / \mathrm{L}$ & 78 & 3 & 0.001 & 0.005 & $<0.004$ & $<0.008$ \\
Orthophosphate & $\mathrm{mg} / \mathrm{L}$ & 66 & 0 & $\mathrm{NA}$ & $\mathrm{NA}$ & $<0.001$ & $<0.012$ \\
Total nitrogen & $\mathrm{mg} / \mathrm{L}$ & 73 & 2 & 0.255 & 0.260 & $<0.05$ & $<0.10$ \\
Dissolved cadmium & $\mu \mathrm{g} / \mathrm{L}$ & 93 & 6 & 0.040 & 0.259 & $<0.016$ & $<1.0$ \\
Total cadmium & $\mu \mathrm{g} / \mathrm{L}$ & 90 & 6 & 0.039 & 0.101 & $<0.014$ & $<1.0$ \\
Dissolved lead & $\mu \mathrm{g} / \mathrm{L}$ & 93 & 22 & 0.074 & 4.82 & $<0.015$ & $<1$ \\
Total lead & $\mu \mathrm{g} / \mathrm{L}$ & 91 & 50 & 0.12 & 8.53 & $<0.04$ & $<1.0$ \\
Dissolved zinc & $\mu \mathrm{g} / \mathrm{L}$ & 93 & 14 & 1.7 & 12 & $<0.6$ & $<20.0$ \\
Total zinc & $\mu \mathrm{g} / \mathrm{L}$ & 90 & 13 & 2.4 & 6.0 & $<1$ & $<10$ \\
\hline
\end{tabular}


higher ambient lead concentrations. Therefore, despite more frequent than ideal detections, total lead data were of sufficient quality for inclusion in the analyses presented in this report.

In contrast to the total lead detections, dissolved lead detections were clustered in successive samples in WY 2011 and WYs 2017-18. This pattern, along with relatively low total lead concentrations in the same blanks and anomalously high dissolved lead values with very low total lead values in regular samples at low-metal sites (SFCDR near Mullan, NFCDR at Enaville, St. Joe River at Ramsdell) during the same time, points to filter contamination as the cause of these detections (Mueller and others, 2015). There are known, documented filter contamination issues with cobalt and manganese that persist despite a 2-liter deionized water rinse of filters before introducing ambient waters (U.S. Geological Survey, 2016a); it is therefore plausible, although presently not formally documented, that similar issues may occur in periodic filter batches for dissolved lead. Generally, dissolved lead blank concentrations were low relative to most site concentrations and these data were of sufficient quality for inclusion in the analyses presented in this report.

However, there were some samples for which filter contamination was more problematic. Increasing trends in dissolved lead over the period of record at low-metal sites (NFCDR at Enaville and St. Joe River at Ramsdell) were investigated carefully to understand the potential impact of filter contamination bias. Several anomalously high dissolved lead and dissolved cadmium concentrations at these sites and at SFCDR near Mullan in WYs 2017-18 were ultimately removed from the analysis because paired total lead and cadmium concentrations were very low, pointing to filter contamination problems. However, it was not possible with the available quality control data to determine whether filter contamination bias also affected much lower concentrations of dissolved lead or whether the increasing trends in dissolved lead concentrations reflect a real environmental trend. Thus, lower dissolved lead concentrations at low-metal sites may be affected by filter contamination bias, but the analyses presented in this report retained these data (and the trends following from them) to be as conservative as possible in the event that these trends indicate real environment change.

From WY 1997 to 2018, 102 split replicate samples were collected (table 6). Split replicate samples were collected by taking two samples from one churn, with identical processing of each. As such, results from these samples represent the effects of processing and analysis variability but minimize the effects of environmental and sampling variability. The median relative percent difference between replicate results for the eight constituents measured ranged from 0 to 4.8 percent. All constituents had occasional occurrences of high relative percent differences, with maximums ranging from 40 to 198 percent, but only 15 percent or fewer of samples for all constituents had relative percent differences greater than 20 percent. For all constituents, the majority of replicates had relative percent differences less than 10 percent (table 6). Overall, no clear patterns in bigger or smaller relative percent differences were observed with time or constituents. Thus, the replicate results from WY 1997 to WY 2019 suggest that sample processing and analysis methods produced data of sufficient quality to be used in the analyses presented hereinafter.

\section{Comparisons to Ambient Water-Quality Criteria}

Generally, the range and median AWQC ratios for dissolved zinc have consistently decreased at most sites in the study area from the mid-1990s to WY 2018 based on simple visual comparison of boxplots (fig. 3; table 7). Nonetheless, the WYs 2014-18 AWQC ratios were well above 1.0 (that is, concentrations were above site-specific standards) at most sites, with median ratios ranging from 1.7 (Pine Creek) to 27 (Seeps north of tailings; table 7). Several sites (SFCDR near Mullan, NFCDR at Enaville, and St. Joe River at Ramsdell) have been consistently below criteria during the period of record (fig. 3) except for two samples above criteria at NFCDR at Enaville during spring runoff events (fig. 3). In WYs 2014-18, median concentrations in the Spokane River

Table 6. Summary of replicate sample results, water years 1997-2018.

[Results summarized from 102 replicate samples collected from April 17, 1997, to September 19, 2018. Symbols: >, greater than; <, less than]

\begin{tabular}{lccccc}
\hline \multicolumn{1}{c}{ Constituent } & $\begin{array}{c}\text { Number of } \\
\text { replicates }\end{array}$ & $\begin{array}{c}\text { Median relative } \\
\text { percent difference }\end{array}$ & $\begin{array}{c}\text { Maximum relative } \\
\text { percent difference }\end{array}$ & $\begin{array}{c}\text { Number of replicates } \\
\text { with relative percent } \\
\text { difference }>\text { 20 percent }\end{array}$ & $\begin{array}{c}\text { Percentage of replicates with } \\
\text { relative percent difference } \\
<10 \text { percent }\end{array}$ \\
\hline Total phosphorus & 69 & 3.8 & 40 & 7 & 50 \\
Orthophosphate & 38 & 0 & 100 & 11 & 26 \\
Dissolved cadmium & 79 & 2.0 & 198 & 14 & 32 \\
Total cadmium & 84 & 2.2 & 195 & 5 & 73 \\
Dissolved lead & 92 & 3.3 & 197 & 4 & 76 \\
Total lead & 97 & 4.8 & 191 & 12 & 69 \\
Dissolved zinc & 96 & 1.7 & 198 & 6 & 70 \\
Total zinc & 96 & 1.4 & 196 & 65 \\
\hline
\end{tabular}




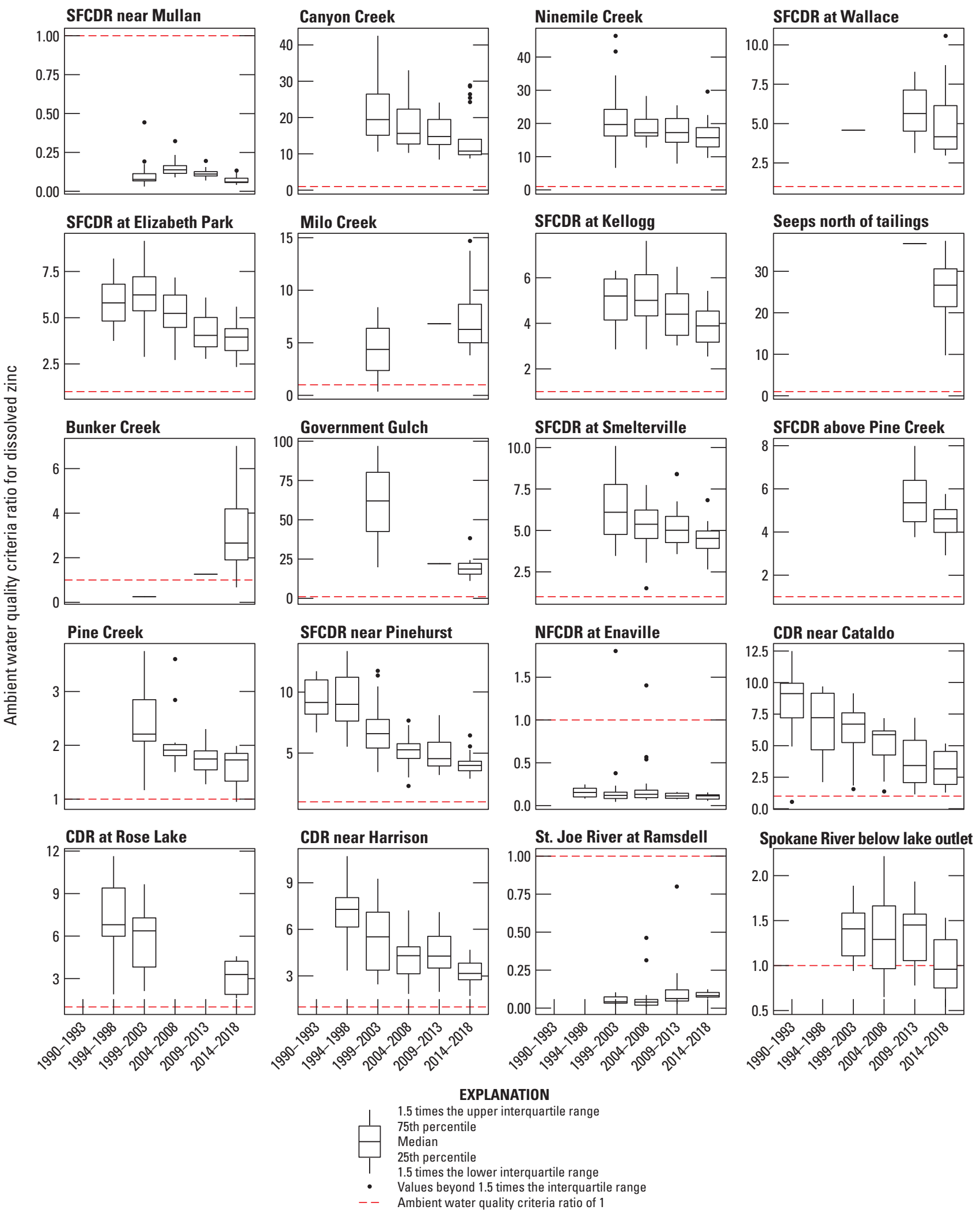

Figure 3. Dissolved zinc ambient water-quality criteria ratios for water years 1990-2018 for sites in the Spokane River watershed, northern Idaho. Site locations are shown in figure 1. Data were not available for all sites for all water years. Boxplots present as lines where the underlying data are limited to fewer than four samples. Abbreviations: CDR, Coeur d'Alene River; NFCDR, North Fork Coeur d'Alene River; SFCDR, South Fork Coeur d'Alene River. 
Table 7. Median ambient water-quality criteria ratios for dissolved cadmium, lead and zinc, water years 1990-2018, for sites in the Spokane River watershed, northern Idaho.

[Data were not available for all sites for all water years. Abbreviations: AWQC, ambient water-quality criteria; CDR, Coeur d'Alene River; NFCDR, North Fork Coeur d'Alene River; SFCDR, South Fork Coeur d'Alene River; NA, not available]

\begin{tabular}{|c|c|c|c|c|c|}
\hline \multirow{2}{*}{$\begin{array}{c}\text { Site name } \\
\text { (short, as used in this report) }\end{array}$} & \multirow{2}{*}{$\begin{array}{c}\text { Time } \\
\text { interval } \\
\text { (water years) }\end{array}$} & \multirow{2}{*}{$\begin{array}{l}\text { Number } \\
\text { of total } \\
\text { samples }\end{array}$} & \multicolumn{3}{|c|}{ Median AWOC ratio } \\
\hline & & & $\begin{array}{l}\text { Dissolved } \\
\text { cadmium }\end{array}$ & $\begin{array}{l}\text { Dissolved } \\
\text { lead }\end{array}$ & $\begin{array}{l}\text { Dissolved } \\
\text { zinc }\end{array}$ \\
\hline NFCDR at Enaville & 1994-98 & 13 & NA & NA & 0.2 \\
\hline NFCDR at Enaville & 1999-2003 & 61 & 0.1 & 0.2 & 0.1 \\
\hline NFCDR at Enaville & $2004-08$ & 36 & 0.2 & 0.2 & 0.1 \\
\hline NFCDR at Enaville & $2009-13$ & 23 & 0.1 & 0.2 & 0.1 \\
\hline NFCDR at Enaville & $2014-18$ & 18 & 0.2 & 0.2 & 0.1 \\
\hline SFCDR near Mullan & 1999-2003 & 21 & NA & 0.1 & 0.1 \\
\hline SFCDR near Mullan & 2004-08 & 11 & 0.1 & 0.0 & 0.1 \\
\hline SFCDR near Mullan & $2009-13$ & 9 & 0.1 & 0.0 & 0.1 \\
\hline SFCDR near Mullan & 2014-18 & 10 & 0.1 & 0.0 & 0.1 \\
\hline Canyon Creek & 1999-2003 & 42 & 28 & 2 & 19 \\
\hline Canyon Creek & 2004-08 & 25 & 22 & 1.1 & 16 \\
\hline Canyon Creek & $2009-13$ & 23 & 20 & 1.4 & 15 \\
\hline Canyon Creek & $2014-18$ & 21 & 15 & 1.2 & 11 \\
\hline Ninemile Creek & 1999-2003 & 44 & 24 & 1.7 & 20 \\
\hline Ninemile Creek & 2004-08 & 11 & 24 & 1.1 & 17 \\
\hline Ninemile Creek & $2009-13$ & 24 & 23 & 1.4 & 17 \\
\hline Ninemile Creek & 2014-18 & 21 & 19 & 1.3 & 16 \\
\hline SFCDR at Wallace & $1999-2003$ & 1 & 7.3 & 1.3 & 4.6 \\
\hline SFCDR at Wallace & 2009-13 & 15 & 6.6 & 0.4 & 5.6 \\
\hline SFCDR at Wallace & $2014-18$ & 20 & 5.2 & 0.3 & 4.2 \\
\hline SFCDR at Elizabeth Park & 1994-98 & 14 & 8.7 & 0.4 & 5.8 \\
\hline SFCDR at Elizabeth Park & $1999-2003$ & 44 & 8.7 & 0.3 & 6.2 \\
\hline SFCDR at Elizabeth Park & 2004-08 & 37 & 6.7 & 0.2 & 5.2 \\
\hline SFCDR at Elizabeth Park & $2009-13$ & 23 & 5.4 & 0.2 & 4 \\
\hline SFCDR at Elizabeth Park & $2014-18$ & 21 & 5.1 & 0.1 & 3.9 \\
\hline SFCDR at Kellogg & $1999-2003$ & 4 & 8.6 & 0.5 & 5.2 \\
\hline SFCDR at Kellogg & 2004-08 & 20 & 6.5 & 0.3 & 5 \\
\hline SFCDR at Kellogg & $2009-13$ & 23 & 5.6 & 0.3 & 4.4 \\
\hline SFCDR at Kellogg & $2014-18$ & 21 & 5.2 & 0.2 & 3.9 \\
\hline Government Gulch & 1999-2003 & 18 & 390 & 0.6 & 62 \\
\hline Government Gulch & $2009-13$ & 1 & 120 & 0.2 & 22 \\
\hline Government Gulch & $2014-18$ & 10 & 94 & 0.5 & 19 \\
\hline SFCDR at Smelterville & $1999-2003$ & 15 & 9 & 0.3 & 6.1 \\
\hline SFCDR at Smelterville & $2004-08$ & 37 & 7.5 & 0.2 & 5.4 \\
\hline SFCDR at Smelterville & $2009-13$ & 23 & 7.5 & 0.2 & 5 \\
\hline SFCDR at Smelterville & 2014-18 & 24 & 6.6 & 0.2 & 4.5 \\
\hline SFCDR above Pine Creek & 2009-13 & 23 & 7.5 & 0.2 & 5.4 \\
\hline SFCDR above Pine Creek & $2014-18$ & 21 & 6 & 0.2 & 4.6 \\
\hline Pine Creek & 1999-2003 & 45 & 1.8 & 0.1 & 2.2 \\
\hline Pine Creek & $2004-08$ & 11 & 1.4 & 0.1 & 1.9 \\
\hline
\end{tabular}


Table 7. Median ambient water-quality criteria ratios for dissolved cadmium, lead and zinc, water years 1990-2018, for sites in the Spokane River watershed, northern Idaho.-Continued

[Data were unavailable for all sites for all water years. Abbreviations: AWQC, ambient water-quality criteria; CDR, Coeur d'Alene River; NFCDR, North Fork Coeur d'Alene River; SFCDR, South Fork Coeur d'Alene River; NA, not available]

\begin{tabular}{|c|c|c|c|c|c|}
\hline \multirow[b]{2}{*}{ Site name (short, as used in this report) } & \multirow{2}{*}{$\begin{array}{c}\text { Time } \\
\text { interval } \\
\text { (water years) }\end{array}$} & \multirow{2}{*}{$\begin{array}{l}\text { Number } \\
\text { of total } \\
\text { samples }\end{array}$} & \multicolumn{3}{|c|}{ Median AWOC ratio } \\
\hline & & & $\begin{array}{l}\text { Dissolved } \\
\text { cadmium }\end{array}$ & $\begin{array}{c}\text { Dissolved } \\
\text { lead }\end{array}$ & $\begin{array}{l}\text { Dissolved } \\
\text { zinc }\end{array}$ \\
\hline Pine Creek & $2009-13$ & 9 & 1.4 & 0.1 & 1.7 \\
\hline Pine Creek & $2014-18$ & 11 & 1.2 & 0.1 & 1.7 \\
\hline SFCDR near Pinehurst & $1990-93$ & 14 & 12 & 0.2 & 9.1 \\
\hline SFCDR near Pinehurst & 1994-98 & 24 & 9.3 & 0.3 & 9 \\
\hline SFCDR near Pinehurst & 1999-2003 & 74 & 8 & 0.3 & 6.6 \\
\hline SFCDR near Pinehurst & 2004-08 & 37 & 6.7 & 0.2 & 5.3 \\
\hline SFCDR near Pinehurst & $2009-13$ & 23 & 6.1 & 0.2 & 4.5 \\
\hline SFCDR near Pinehurst & $2014-18$ & 21 & 5.1 & 0.2 & 4 \\
\hline CDR near Cataldo & $1990-93$ & 13 & 8.7 & 4.3 & 9.1 \\
\hline CDR near Cataldo & 1994-98 & 14 & 7.9 & 1.8 & 7.2 \\
\hline CDR near Cataldo & $1999-2003$ & 22 & 6.5 & 1.9 & 6.7 \\
\hline CDR near Cataldo & 2004-08 & 11 & 5.4 & 1.8 & 5.9 \\
\hline CDR near Cataldo & $2009-13$ & 17 & 3.2 & 1.2 & 3.4 \\
\hline CDR near Cataldo & $2014-18$ & 22 & 3.1 & 1.5 & 3.2 \\
\hline CDR at Rose Lake & 1994-98 & 16 & 7.1 & 4.9 & 6.8 \\
\hline CDR at Rose Lake & 1999-2003 & 16 & 6.3 & 3.9 & 6.4 \\
\hline CDR at Rose Lake & $2014-18$ & 17 & 3.1 & 3.5 & 3.3 \\
\hline CDR near Harrison & 1994-98 & 18 & 6.3 & 11 & 7.3 \\
\hline CDR near Harrison & 1999-2003 & 39 & 5.1 & 8.1 & 5.5 \\
\hline CDR near Harrison & 2004-08 & 40 & 3.5 & 7.2 & 4.3 \\
\hline CDR near Harrison & $2009-13$ & 29 & 3.6 & 12 & 4.3 \\
\hline CDR near Harrison & $2014-18$ & 24 & 2.9 & 8.3 & 3.2 \\
\hline St. Joe River at Ramsdell & 1999-2003 & 5 & 0.1 & 0.2 & 0.0 \\
\hline St. Joe River at Ramsdell & 2004-08 & 36 & 0.2 & 0.1 & 0.0 \\
\hline St. Joe River at Ramsdell & $2009-13$ & 30 & 0.1 & 0.1 & 0.1 \\
\hline St. Joe River at Ramsdell & 2014-18 & 22 & 0.2 & 0.2 & 0.1 \\
\hline Spokane River below lake outlet & 1999-2003 & 7 & 1.0 & 0.4 & 1.4 \\
\hline Spokane River below lake outlet & 2004-08 & 38 & 0.8 & 0.4 & 1.3 \\
\hline Spokane River below lake outlet & $2009-13$ & 30 & 0.8 & 0.3 & 1.5 \\
\hline Spokane River below lake outlet & 2014-18 & 23 & 0.7 & 0.4 & 1.0 \\
\hline Milo Creek & $1999-2003$ & 2 & 6.9 & 8.9 & 4.4 \\
\hline Milo Creek & $2009-13$ & 1 & 5.6 & 11 & 6.8 \\
\hline Milo Creek & 2014-18 & 10 & 6.1 & 11 & 6.3 \\
\hline Bunker Creek & 1999-2003 & 1 & 0.8 & NA & 0.3 \\
\hline Bunker Creek & 2009-13 & 1 & 3.6 & 0.0 & 1.3 \\
\hline Bunker Creek & $2014-18$ & 13 & 4.1 & 0.0 & 2.7 \\
\hline Seeps north of tailings & $2009-13$ & 1 & 57 & 0.0 & 37 \\
\hline Seeps north of tailings & $2014-18$ & 10 & 22 & 0.0 & 27 \\
\hline
\end{tabular}


below lake outlet met criteria for the first time in the period of record (fig. 3). Apparent increases in dissolved zinc AWQC ratios at a few sites (SFCDR at Wallace, Milo Creek and Bunker Creek; fig. 3) over the period of record mainly reflect sparse underlying data in periods preceding WYs 2014-18 (table 7).

Similar to dissolved zinc, the range and median AWQC ratios for dissolved cadmium have decreased at most sites in the study area over the period of record based on visual comparison of boxplots (fig. 4; table 7). The WYs 2014-18 concentrations were still well above site-specific criteria at most sites, with median ratios ranging from 1.2 (Pine Creek) to 94 (Government Gulch; table 7). Several sites have always or usually been below site-specific criteria (SFCDR near Mullan, NFCDR at Enaville, St. Joe River at Ramsdell, and Spokane River below lake outlet) during the period of record except during occasional high streamflow events (fig. 4).

The apparent increase in dissolved cadmium AWQC over the period of record at Bunker Creek (fig. 4) reflects the sparse underlying data (only two samples) in the periods preceding WYs 2014-18 (table 7).

The range and median AWQC ratios for dissolved lead have generally either remained about the same or decreased at most sites in the study area over the period of record based on simple visual comparison of boxplots (fig. 5). The AWQC ratios indicate that dissolved lead concentrations met sitespecific criteria most of the time for most sites in the study area; exceptions primarily occurred during high streamflow events (fig. 5). However, several sites generally did not meet site-specific criteria (Canyon Creek, Ninemile Creek, Milo Creek, CDR near Cataldo, CDR at Rose Lake and CDR near Harrison), with WYs 2014-18 median AWQC ratios ranging from 1.2 (Canyon Creek) to 11 (Milo Creek). Of these sites, the range and median AWQC ratios have generally decreased over the period of record in Canyon Creek, Ninemile Creek and CDR near Cataldo (fig. 5). However, the range and median AWQC ratios have remained about the same in CDR at Rose Lake and CDR near Harrison (fig. 5). The apparent increases in the Milo Creek and Bunker Creek AWQC ratios are caused by sparse data (three and two samples, respectively) in periods preceding WYs 2014-19 (table 7).

\section{Model Performance}

Annual mean concentrations and annual total loads were generated by the WRTDS_K models, and trends in concentrations and loads were calculated from flow-normalized annual mean concentrations and annual total loads generated by the WRTDS models and bootstrapped confidence intervals. It is therefore worthwhile to discuss the underlying model development and performance before describing the trends. In total, 85 models were developed, comprising 9 constituents and 12 sites (table 3). Dissolved zinc models were successfully developed at all 12 sites; orthophosphate models were only developed for 3 sites due to high proportions of censored data. Models were developed for all nine constituents at SFCDR near Pinehurst and CDR near Harrison, but for only three parameters at CDR near Cataldo due to a gap in data collection in the mid-2000s. Generally, the longest records were for SFCDR near Pinehurst, and the shortest were for the SFCDR at Kellogg, the Spokane River below lake outlet and the St. Joe River at Ramsdell. Based on careful review of the underlying data, models, and diagnostics (appendix 2), several implausibly high or low outliers that had undue influence on the models were removed from datasets. However, in most instances, outliers were retained regardless of their influence on the models because they likely represent actual environment conditions.

Model performance was evaluated in part by using the flux bias statistic. For the WRTDS model, the flux bias statistic provides an indication of how closely the model estimated flux values align with actual sampled flux (that is, the sampled concentrations multiplied by discharge). Note that this bias measure is designed to be specific to bias in flux (rather than concentration), and thus a great deal of weight in the calculation is associated with the days of high discharge. The flux bias statistics are reported in table 3 and displayed by parameter and site in fig. 6. Generally, the WRTDS models somewhat underpredicted flux for most parameters (fig. 6a). The WRTDS model performed best for dissolved cadmium, dissolved zinc, and orthophosphate; overall model bias for these constituents fell within -0.1 and 0.1 . More than half of the model biases for total nitrogen and total zinc also fell within these bands. The WRTDS models performed least well for total lead and total phosphorus, although even for these constituents the flux bias statistic for most of the models was less than -0.5 (fig. 6a). Based on the known transport behavior of constituents in the study area (Clark and Mebane, 2014), the models performed best for constituents that have a strong negative correlation between streamflow and concentration (that is, dissolved cadmium and dissolved zinc) and performed less well for constituents that are transported at high concentrations in particulate form at very high streamflows (that is, total lead, total phosphorus, total zinc, and total cadmium). The varied model performances likely reflect limitations in the underlying dataset; there were many samples with varying dissolved zinc and cadmium concentrations across a range of streamflows, but samples with high concentrations of total constituents at high streamflows were relatively sparser due to the rarer nature of these streamflow events. 


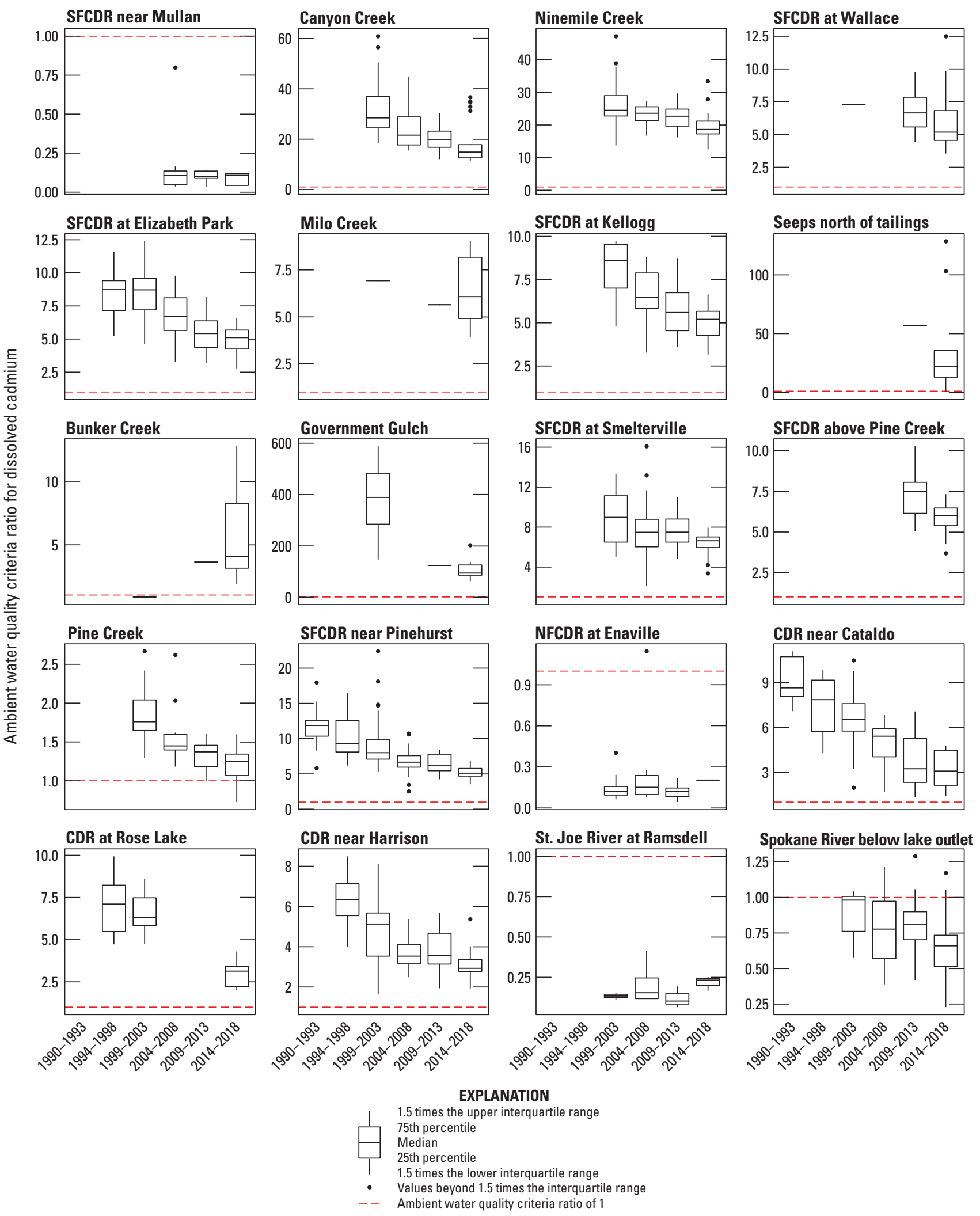

Figure 4. Dissolved cadmium ambient water-quality criteria ratios for water years 1990-2018 for sites in the Spokane River watershed, northern Idaho. Site locations are shown in figure 1. Data were not available for all sites for all water years. Boxplots present as lines where the underlying data are limited to fewer than four samples. Abbreviations: CDR, Coeur d'Alene River; NFCDR, North Fork Coeur d'Alene River; SFCDR, South Fork Coeur d'Alene River. 

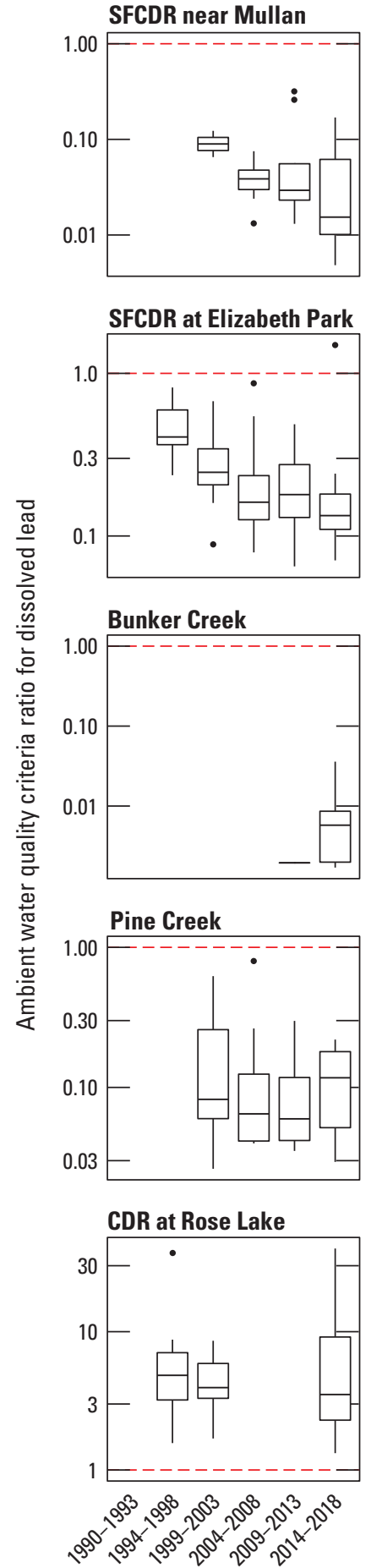
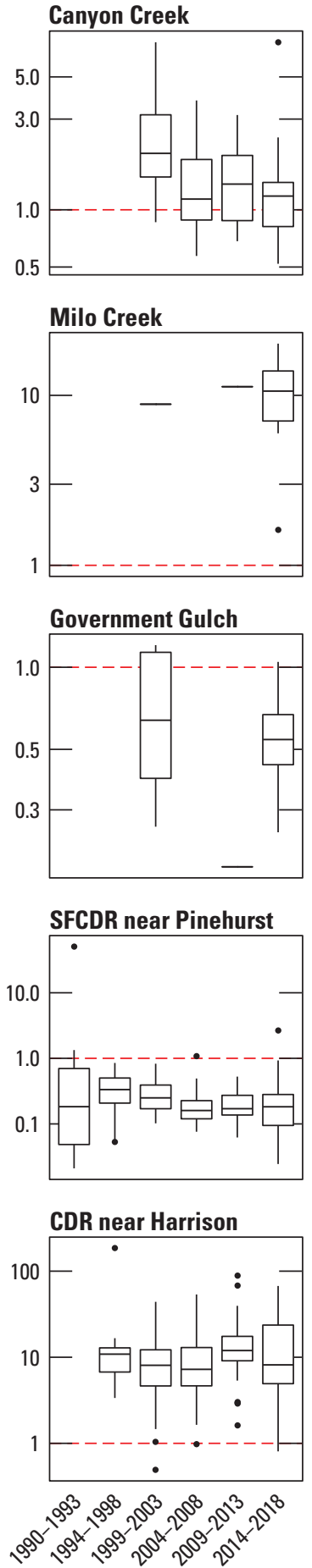
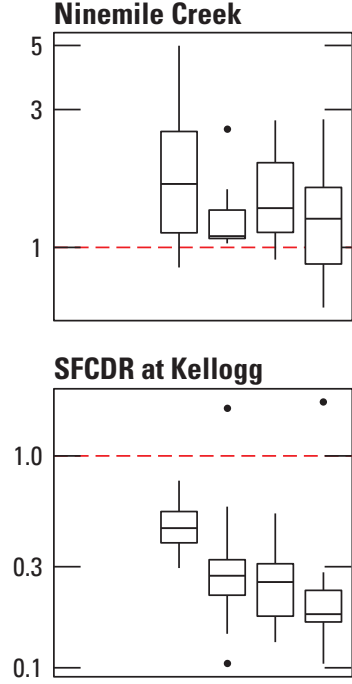

SFCDR at Smelterville
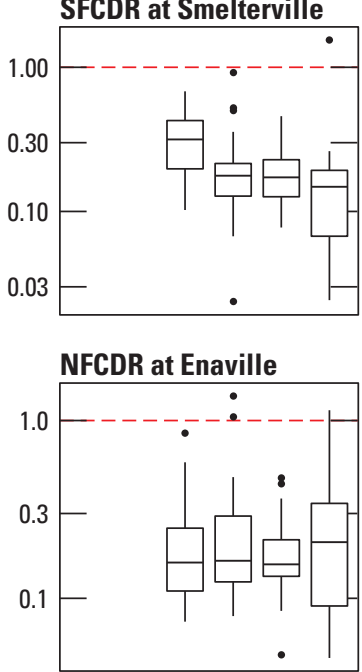

St. Joe River at Ramsdell

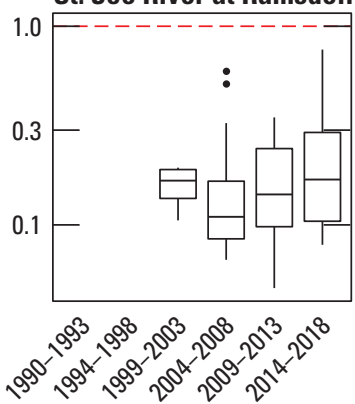

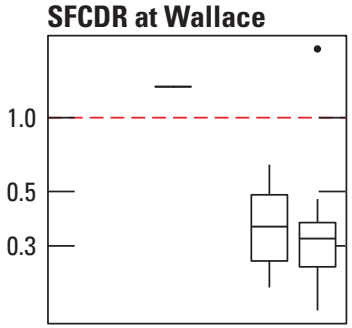

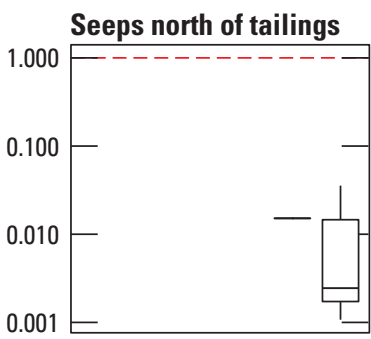

SFCDR above Pine Creek
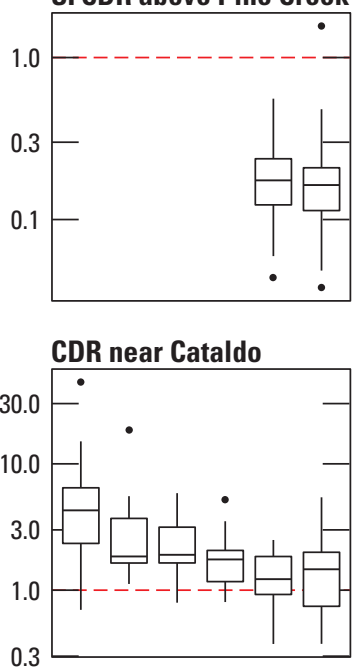

Spokane River below lake outlet

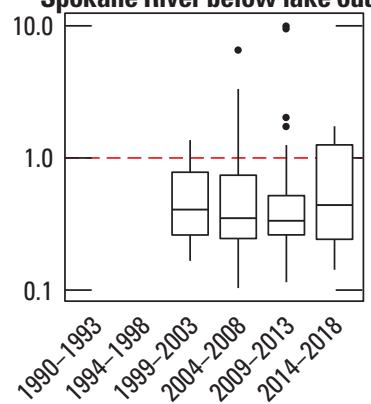

\section{EXPLANATION}

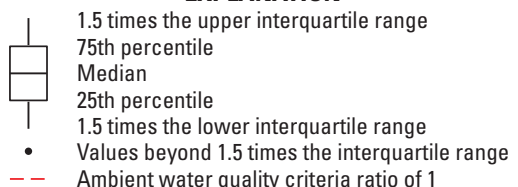

Figure 5. Dissolved lead ambient water-quality criteria (AWOC) ratios for water years 1990-2018 for sites in the Spokane River watershed, northern Idaho. Site locations are shown in figure 1. Data were not available for all sites for all water years. Boxplots present as lines where the underlying data are limited to fewer than four samples. Abbreviations: CDR, Coeur d'Alene River; NFCDR, North Fork Coeur d'Alene River; SFCDR, South Fork Coeur d'Alene River. 


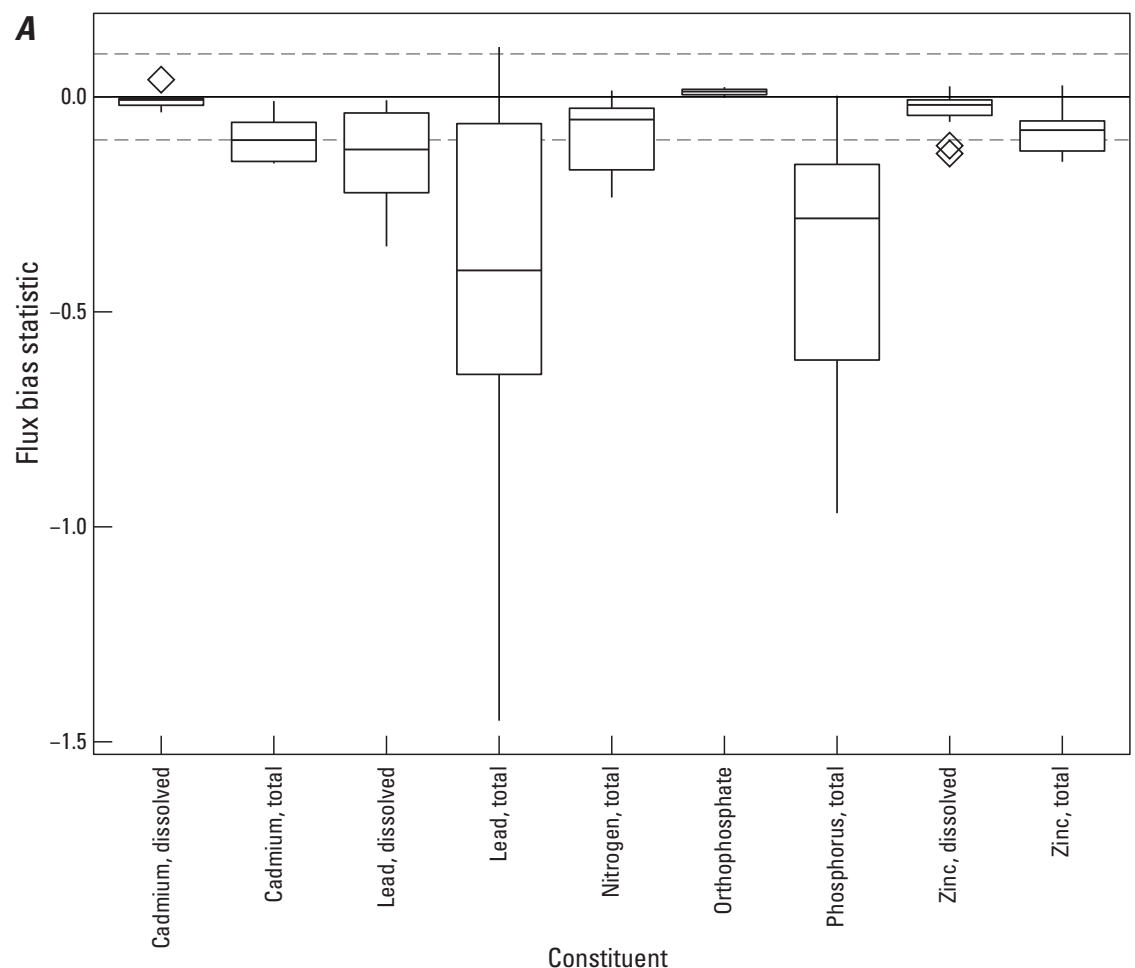

EXPLANATION

Range of flux bias statistic for each constituent 1.5 times the upper interquartile range 75th percentile

Median

25th percentile

1.5 times the lower interquartile range

$\diamond$ Values beyond 1.5 times the interquartile range

- - - Flux bias statistic at 0.10 and -0.10

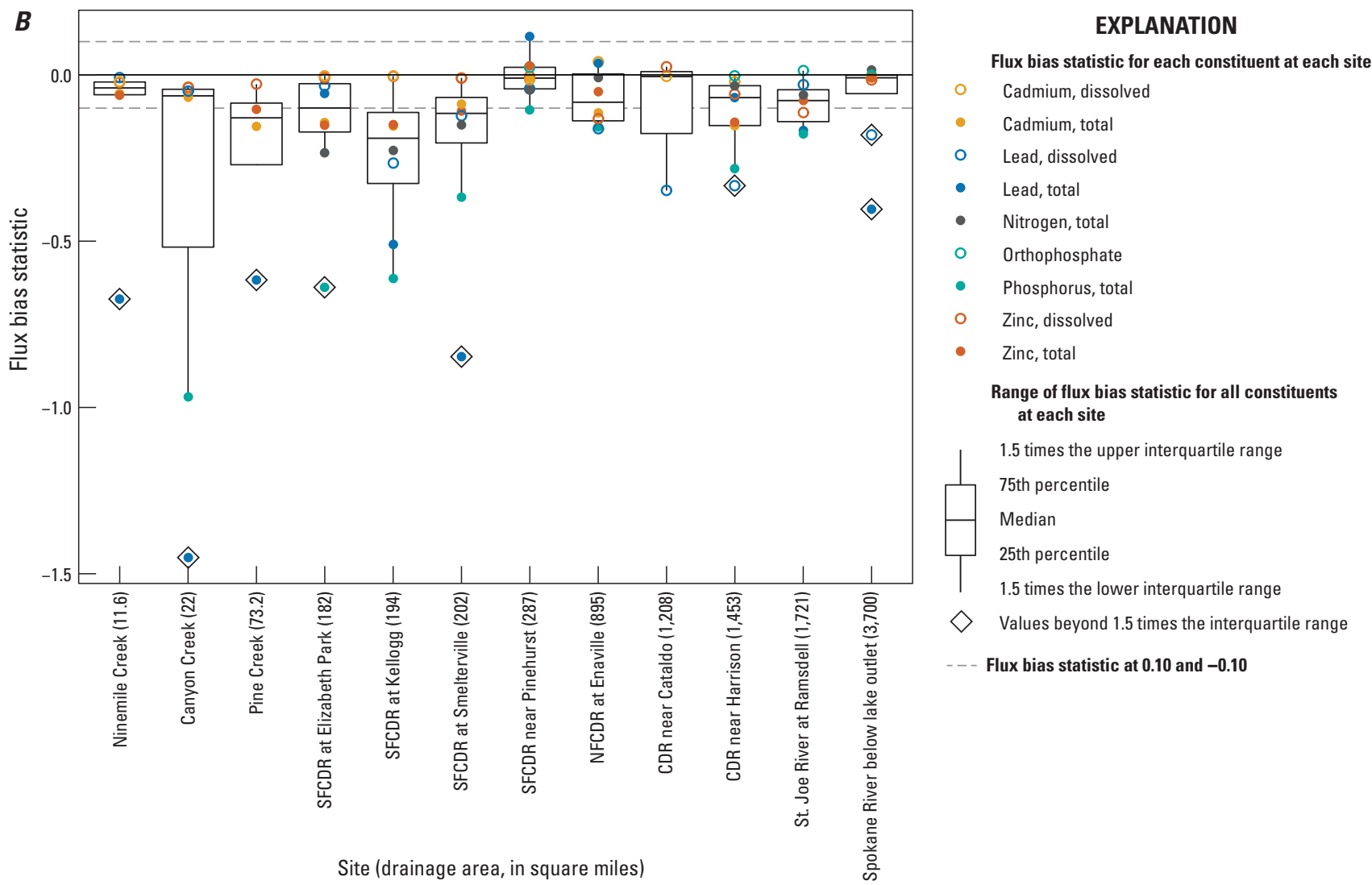

Figure 6. Flux bias statistics associated with Weighted Regressions on Time, Discharge and Season (WRTDS) models for water years 1990-2018, grouped by $(A)$ parameter and $(B)$ site, Spokane River watershed, northern Idaho. Site locations are shown in figure 1. Models were not generated for all constituents at all sites. Abbreviations: CDR, Coeur d'Alene River; NFCDR, North Fork Coeur d'Alene River; SFCDR, South Fork Coeur d'Alene River. 
Looking at model performance by site (fig. 6b; table 3), the flux bias statistics were closest to 0 for sites with the most data or the longest records (NFCDR at Enaville, SFCDR at Elizabeth Park, SFCDR near Pinehurst, and CDR near Harrison). Sites with shorter records (SFCDR at Kellogg and SFCDR at Smelterville), smaller streams (Canyon Creek and Ninemile Creek) and sites with sparse data over intervals in the middle of the record (CDR near Cataldo) generally had bigger (that is, further from 0 ) flux bias statistics (fig. 6b; table 3). Poor model performance tended to happen at sites with smaller drainage areas. It is generally more difficult to obtain enough samples at the highest discharges at these sites because the duration of very high discharge tends to be short. The information on flux bias can be useful in planning for future sampling efforts; for example, sites where the flux bias statistic is large in absolute value are good candidates for high emphasis on high flow sampling in the future. Moreover, for most sites the biggest flux bias statistics were associated with models for constituents with particulate transport (for example, total lead and total phosphorus). This was particularly true for sites higher in the CDR watershed (tributaries and the SFCDR sites upstream of Pinehurst) which have smaller numbers of high streamflow (and hence, high concentration) samples. This is partly a function of shorter records at many of these sites and partly of the flashy nature of high-streamflow, high-transport events. The flux bias statistics for dissolved lead were higher at the downstream end of the CDR watershed (SFCDR near Pinehurst, CDR near Cataldo, and CDR near Harrison) and may reflect more complicated transport dynamics for this constituent at the downstream end of the CDR watershed (fig. 6b). Generally, higher dissolved lead concentrations are associated with higher streamflows, but dissolved lead concentrations can also increase at low streamflows, particularly at the CDR sites (Zinsser, 2018).

At present (2020), there is no a method to systematically evaluate bias in the WRTDS_K models. However, because the Kalman filtering procedure in WRTDS_K uses actual sample concentrations in place of model estimates on days with samples and weights estimates on proximal days accordingly, the WRTDS_K models may do a better job than WRTDS at estimating high particulate transport events. The WRTDS_K models, however, would fundamentally still be limited by how well the underlying samples represent transport dynamics during high streamflow events. For example, in a system where hysteresis is important, improved estimates are feasible if the underlying samples generally included samples from both the rising and falling limbs of major flow events. Nonetheless, given the high negative biases associated with particulate constituents in this report, WRTDS_K estimates may provide a substantial improvement over WRTDS estimates, but there is not currently a systematic way to describe this effect for these data. The basis for choosing to use the WRTDS_K stems from Lee and others (2019), where these estimates were compared with other common methods and found to be more accurate.
In summary, review of the flux bias statistics (and other model diagnostics, appendix 2) suggest that flow-normalized annual mean concentration and annual total load results somewhat underpredict actual values overall, and these underestimates are likely to be greatest for constituents with high-streamflow, particulate-driven transport (that is, total lead and total phosphorus). Based on statistical theory and previous experiments, it is likely the case that WRTDS_K estimates for annual mean concentration and annual total load results have less negative bias (Lee and others, 2019; Zhang and Hirsch, 2019) than WRTDS estimates, but this effect cannot currently be quantified for these models. Thus, as with all models, interpretation of concentrations, loads, and trends are susceptible to weaknesses in the underlying models. Nonetheless, the WRTDS_K estimates presented here are based on robust statistical techniques and likely represent more accurate estimates than previous LOADEST-derived estimates or the original WRTDS estimates based on extensive model comparison work completed by Lee and others (2019) and Zhang and Hirsch (2019).

\section{Trends in Concentrations and Loads}

At the most basic level, WRTDS_K annual mean concentrations and loads can be used to give a general sense of average conditions at sites in the study area. To this end, the annual mean concentration and load for each parameter at each modeled site are shown in figure 7, and the WYs 2014-18 5-year mean of the annual mean concentrations are presented in table 8 . This table and figure provide a general overview of constituent concentrations and loads in the study area over the most recent 5-year period. For example, figure 7 shows that concentrations generally decreased from upstream to downstream in the study area and loads generally increased. Concentrations and loads in the NFCDR (which is much less affected by mining than the SFCDR) and in the St. Joe River (which is unaffected by mining) were low relative to SFCDR, CDR main stem, and Spokane River sites. Concentrations in mining-affected tributaries (Ninemile, Canyon, and Pine Creeks) tended to be high, but loads from these tributaries were relatively low due to low streamflows. In contrast, concentrations in CDR near Harrison were low (cadmium and zinc) or comparable (lead) to the SFCDR sites, but loads were high due to more streamflow (fig. 7). In the SFCDR and tributary sites, most of the cadmium and zinc (greater than 90 percent) was present in the dissolved fraction, whereas most of the lead (greater than 65 percent) was present in the particulate fraction. While those same overall patterns were true for CDR near Harrison, the particulate fractions for zinc (about 15 percent), cadmium (about 25 percent), and lead (about 90 percent) were all somewhat higher than in the SFCDR sites (table 8). Note that particulate concentrations were not directly measured in these data but instead are inferred as the difference between the total constituent concentration and the dissolved (filtered) constituent concentrations. For the three sites 

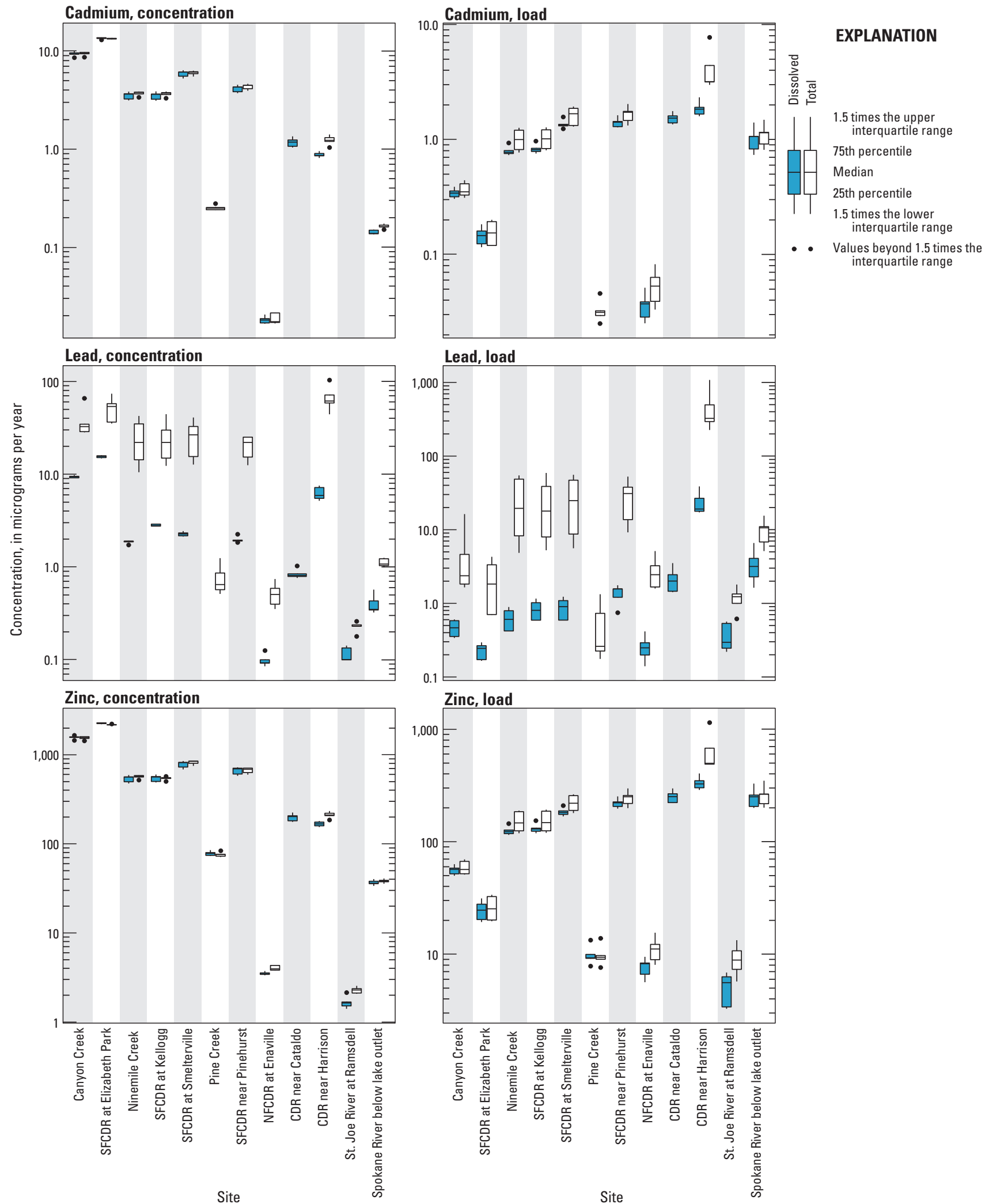

Figure 7. Annual mean concentrations and loads for cadmium, lead, and zinc from Weighted Regressions on Time, Discharge and Season with Kalman filtering (WRTDS_K) models for water years 2014-18 for sites in the Spokane River watershed, northern Idaho. Site locations are shown in figure 1. Data were not available for all sites for all water years. Abbreviations: CDR, Coeur d'Alene River; NFCDR, North Fork Coeur d'Alene River; SFCDR, South Fork Coeur d'Alene River. 
Table 8. Five-year mean of annual mean concentrations for total and dissolved constituents derived from Weighted Regression on Time, Discharge and Season with Kalman filtering models for sites in the Spokane River watershed, northern Idaho, water years 2014-18.

[Sufficient data were not available at all sites for all water years, and models were not generated for all constituents at all sites. Abbreviations: CDR, Coeur d'Alene River; NA, not applicable; NFCDR, North Fork Coeur d'Alene River; SFCDR, South Fork Coeur d'Alene River; WRTDS_K, Weighted Regressions on Time, Discharge and Season with Kalman filtering; $\mu \mathrm{g} / \mathrm{L}$, microgram per liter]

\begin{tabular}{|c|c|c|c|c|c|c|c|c|}
\hline $\begin{array}{c}\text { Site name } \\
\text { (short, as used } \\
\text { in this report) }\end{array}$ & $\begin{array}{c}\text { Dissolved } \\
\text { cadmium } \\
(\mu \mathrm{g} / \mathrm{L})\end{array}$ & $\begin{array}{c}\text { Total } \\
\text { cadmium } \\
(\mu \mathrm{g} / \mathrm{L})\end{array}$ & $\begin{array}{c}\text { Dissolved } \\
\text { lead } \\
(\mu \mathrm{g} / \mathrm{L})\end{array}$ & $\begin{array}{c}\text { Total } \\
\text { lead } \\
(\mu \mathrm{g} / \mathrm{L})\end{array}$ & $\begin{array}{l}\text { Dissolved } \\
\text { zinc } \\
(\mu \mathrm{g} / \mathrm{L})\end{array}$ & $\begin{array}{c}\text { Total } \\
\text { zinc } \\
(\mu \mathrm{g} / \mathrm{L})\end{array}$ & $\begin{array}{c}\text { Ortho- } \\
\text { phosphate } \\
\text { ( } \mu \mathrm{g} / \mathrm{L})\end{array}$ & $\begin{array}{c}\text { Total } \\
\text { phosphorus } \\
(\mu \mathrm{g} / \mathrm{L})\end{array}$ \\
\hline NFCDR at Enaville & 0.018 & 0.019 & 0.098 & 0.514 & 3.51 & 4.06 & NA & 7.71 \\
\hline Canyon Creek & 9.31 & 9.35 & 9.37 & 38.0 & 1560 & 1536 & NA & 5.48 \\
\hline Ninemile Creek & 13.4 & 13.3 & 15.5 & 51.4 & 2244 & 2170 & NA & NA \\
\hline SFCDR at Elizabeth Park & 3.50 & 3.69 & 1.85 & 24.8 & 537 & 565 & NA & 10.3 \\
\hline SFCDR at Smelterville & 5.85 & 5.96 & 2.26 & 25.7 & 777 & 816 & NA & 33.8 \\
\hline Pine Creek & NA & 0.25 & NA & 0.763 & 77.9 & 75.8 & NA & NA \\
\hline SFCDR near Pinehurst & 4.13 & 4.32 & 1.97 & 20.1 & 660 & 665 & 15.5 & 39.9 \\
\hline CDR near Cataldo & 1.18 & NA & 0.84 & NA & 198 & NA & NA & NA \\
\hline
\end{tabular}

where both total phosphorus and orthophosphate models were available (SFCDR near Pinehurst, CDR near Harrison, and St. Joe River at Ramsdell), dissolved orthophosphate comprised 20-40 percent of the total phosphorus (table 8).

The WRTDS_K annual mean concentration and annual total load and WRTDS flow-normalized annual mean concentration and annual total load for each site, parameter, and water year that were modeled are presented in Zinsser (2020). For each site, parameter, and water year that were modeled in WRTDS and had successful bootstrapped confidence intervals constructions (in 3 out of 170 cases, multiple bootstrap replicate models did not converge and confidence intervals could not be constructed), the total change in flow-normalized concentrations and loads over the period of record and during WYs 2009-18, as well as the statistical likelihood associated with the direction of these changes, are presented in Zinsser (2020).

It may help the reader to better understand the meaning of the results shown in Zinsser (2020) to take two specific analyses and provide a short narrative of their meaning. First, consider the total lead load results at SFCDR at Elizabeth Park for the full period of record. The Zinsser (2020) entry says that the total load change was -21 metric tons, which means that, over the full period of record (WYs 1993-2018), the estimated change in annual load was a decrease of 21 metric tons. To produce this estimate, all the data during this period were evaluated and used to construct a smooth representation of change, and the value at the end of this representation was 21 metric tons lower than the value at the beginning (that is, the change is not just a comparison of the first and last years). This change was equivalent to a 48 percent decrease in total load (change divided by the initial year value). The statistical likelihood of the change was 0.12 and called "likely down." What this means is that, although we cannot state with certainty that there was a decrease over this period, there was only about a 0.12 probability that the trend was actually upwards and, consequently, a 0.88 probability that the trend was actually downward. In short, the evidence for downtrend is strong, but not ironclad. In contrast to that result, we can look at the total lead load trend at SFCDR at Elizabeth Park for WYs 2009-18. The estimated change in annual load over the period was -1.6 metric tons. This change was equivalent to a 6.6 percent decrease over the period, which suggests that the change in this time period was much smaller than over the full of record. However, the trend likelihood was 0.44 which causes this result to be categorized as "about as likely as not." What that means is that even though the best estimate of the change was downwards, there was actually a 0.44 probability that the true change was upwards, and thus the probability that the change was downwards was 0.56 . Because this is rather close to a $50 / 50$ result, we state that it falls in the class of trends that are about as likely to be upwards as they are to be downwards. The idea of approaching trend results from this vantage point has been promoted in recent years by Hirsch and others (2015) and McBride (2019). It is a departure from traditional null hypothesis significance testing and rather focuses on quantifying for the reader the degree to which the analyst is certain or uncertain about the true direction of the trend. 
Zinc

The WRTDS and WRTDS_K model results indicate dramatic declines in dissolved zinc over the period of record. Figure 8 shows the WRTDS_K annual mean concentrations and annual total loads and the WRTDS flow-normalized annual mean concentrations and annual total loads for select sites (SFCDR near Pinehurst, CDR near Harrison, and Spokane River below lake outlet; complete results are in appendix 1). For each of these sites, decreases in dissolved zinc concentrations and loads were observed for the period of record, although the magnitude of the changes and the length of the period of record varies between sites. At SFCDR near Pinehurst and CDR near Harrison, the slope of the change was steepest during the 1990s and less steep thereafter (fig. 8).

In the entire study area over the period of record, flownormalized dissolved zinc concentrations and loads have decreased dramatically, with a high statistical likelihood ("likely down" trends), at every site except the miningunaffected St. Joe River at Ramsdell (Zinsser, 2020; fig. 9). In the SFCDR and CDR, dissolved zinc concentration decreases ranged from 27 percent $(-830 \mu \mathrm{g} / \mathrm{L})$ at Ninemile Creek to 63 percent in both the SFCDR near Pinehurst $(-1,100 \mu \mathrm{g} / \mathrm{L})$ and CDR near Cataldo $(-310 \mu \mathrm{g} / \mathrm{L})$. The dissolved zinc load decreases ranged from 30 percent (-53 metric tons) in SFCDR at Kellogg to 64 percent (-359 metric tons) in SFCDR near Pinehurst (Zinsser, 2020).

In WYs 2009-18, absolute decreases in dissolved zinc concentrations and loads were more modest relative to decreases over the period of record. Nonetheless, flownormalized dissolved zinc concentrations and loads have also decreased, with high statistical likelihood ("likely down" trends), in WYs 2009-18 at every site in the study area (Zinsser, 2020; fig. 9). In the SFCDR and CDR, dissolved zinc concentration decreases ranged from 8.6 percent (-210 $\mu \mathrm{g} / \mathrm{L})$ at Ninemile Creek to 27 percent $(-67 \mu \mathrm{g} / \mathrm{L})$ in CDR near Cataldo. The dissolved zinc load decreases ranged from 17 percent (-65 metric tons) in CDR near Harrison to 26 percent in both Pine Creek (-2.9 metric tons) and CDR near Cataldo (-82 metric tons; Zinsser, 2020).

The difference in load trends from earlier in the period of record to the most recent decade (fig. 8) was also explored with trend slope confidence intervals (fig. 10). For this analysis, data were limited to WYs 1999-2009 and WYs 2009-18 for better comparability; therefore, sites with shorter periods of records were eliminated from this particular analysis, and sites with longer periods of records were truncated. The trend slopes were generally similar in magnitude between the two periods (fig. 10). This suggests that the overall rate of change was similar, although as concentrations and loads decreased in the watershed, the absolute size of the decreases also inherently got smaller. However, note that the time period with the steepest slopes (1990s; fig. 8) was not compared as a necessary trade-off of standardizing the time periods for analysis.

There are several puzzling trends in the dissolved zinc data that warrant more discussion, namely, "likely down" trends at NFCDR at Enaville over the period of record and
WYs 2009-18 and at St. Joe River at Ramsdell in WYs 2009-18. Although the absolute change in load and concentrations at these sites was relatively small, a small change to a small concentration or load can nonetheless represent a large percentage change (Zinsser, 2020; fig. 9). This is somewhat misleading because it causes these changes to appear comparable to those at mining-affected sites. The St. Joe River at Ramsdell has been unaffected by mining, and it is not clear that there is another source of human-caused zinc in this watershed. There was some limited mining in the NFCDR watershed, but cleanup in these areas is not under EPA jurisdiction, and it was beyond the scope of this report to explore the extent and impact of such potential cleanups. In the St. Joe River at Ramsdell, the WYs 2014-18 annual mean concentration $(1.68 \mu \mathrm{g} / \mathrm{L}$; table 8$)$ was close to the current quantitation limit $(2 \mu \mathrm{g} / \mathrm{L})$. This proximity suggests that there is probably more uncertainty in this trend than the statistical likelihood implies, with the uncertainty arising not from the model but from the underlying data themselves. Analytical precision degrades when sample concentrations are close to detection limits (Paul and others, 2016). Annual mean concentrations in the NFCDR $(3.51 \mu \mathrm{g} / \mathrm{L}$; table 8$)$ were higher than the detection limits, but the data collection period at this site was long enough to encompass periods with much higher detection limits (20 $\mu \mathrm{g} / \mathrm{L}$ in the $1990 \mathrm{~s}$; table 5). It is well-established that improper treatment of censored values can affect data analysis (Helsel, 2006), but in the context of WRTDS, which relies on robust maximum likelihood estimation to incorporate censored data, it is unclear what impact large changes in detection limits over time may have on trends in concentration between multiple detection limits. It is also possible that changes in laboratory methods over time may have impacted these low concentration data. However, a full exploration of the potential impacts of these issues (which also extends to low-concentration trends in cadmium and lead) was beyond the scope of this report. In summary, it is unclear that trends in these rivers result from actual environmental change, but the possibility cannot but ruled out and thus the trends are retained here. However, readers are cautioned that there is a possibility these very low concentration trends are artifacts of changes in laboratory precision, methods, detection levels or some other issue arising from the length of the dataset.

The trends and likelihoods for flow-normalized total zinc concentrations and loads are reported in Zinsser (2020). Overall, they closely tracked the trends and likelihoods reported for dissolved zinc, which is consistent with established patterns of zinc transport in the study area where dissolved zinc makes up the majority of total zinc except during very high streamflows (table 8; Clark and Mebane [2014]). One notable difference between dissolved and total zinc load trends was that the statistical likelihood of a downward trend in total zinc load at CDR near Harrison for WYs 2009-18 was only "somewhat likely down." This difference likely reflects the relatively greater transport of particulate zinc in the lower CDR and the fact that different processes govern this transport. 

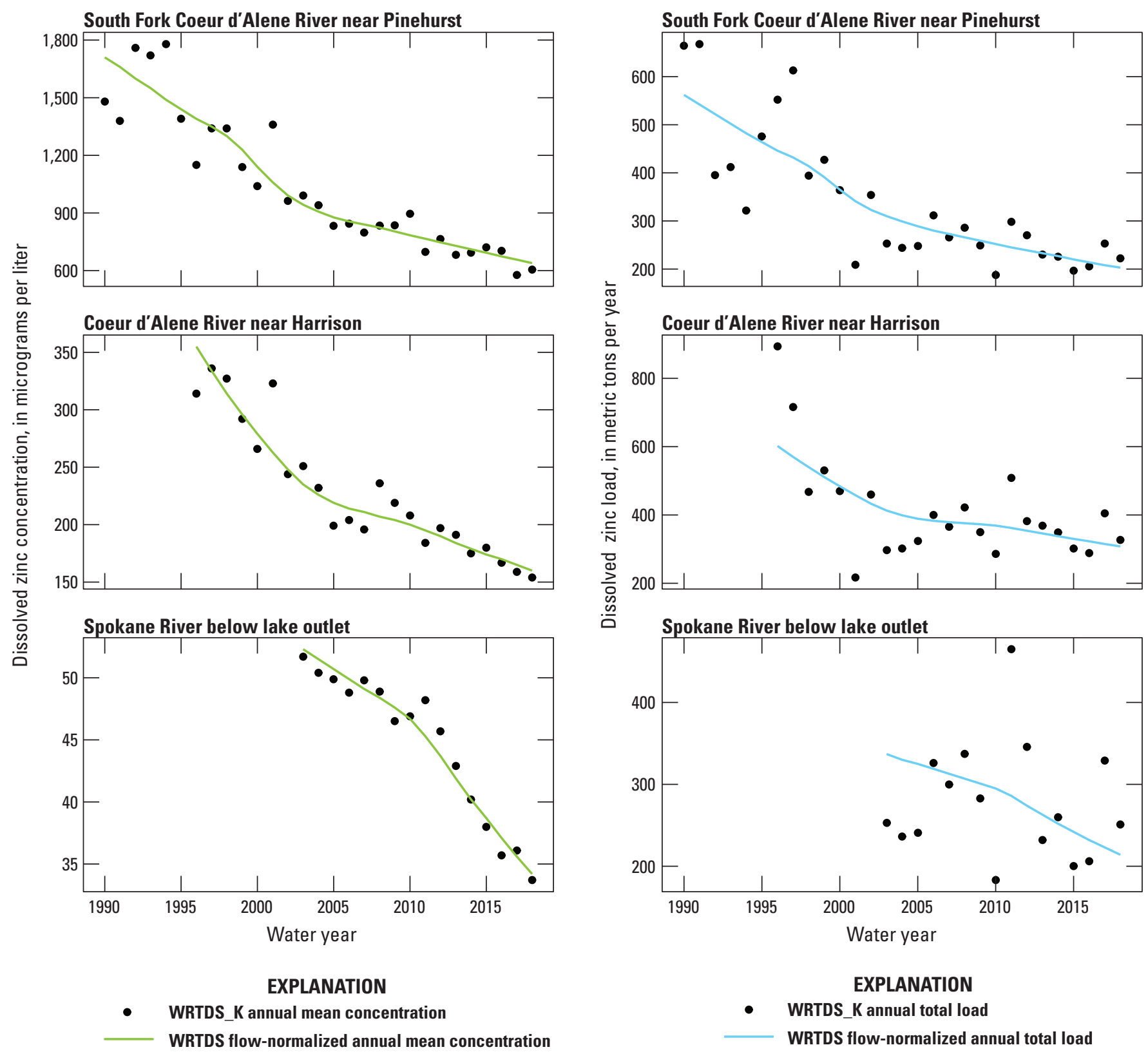

Figure 8. Dissolved zinc annual mean concentrations and annual total loads from Weighted Regressions on Time, Discharge and Season with Kalman filtering (WRTDS_K) and flow-normalized annual mean concentrations and annual total loads from Weighted Regressions on Time, Discharge and Season (WRTDS) for select sites in the Spokane River watershed, northern Idaho, water years 1990-2018. Sites are shown in figure 1. Abbreviations: WRTDS, Weighted Regressions on Time, Discharge and Season; WRTDS_K, Weighted Regressions on Time, Discharge and Season with Kalman filtering.

\section{Cadmium}

The WRTDS and WRTDS_K model results indicate dramatic decreases in dissolved cadmium over the period of record. Figure 11 shows the WRTDS_K annual mean concentrations and annual total loads and the WRTDS flownormalized annual mean concentrations and annual total loads for select sites (SFCDR near Pinehurst, CDR near Harrison and Spokane; complete results are in appendix 1). At each of these sites, decreases in dissolved zinc concentrations and loads occurred, although the period of record and magnitude of the changes varied between sites. The slope of the change was steepest in the 1990s and least steep in the most recent decade (fig. 11).

In the entire study area over the period of record, flownormalized dissolved cadmium concentrations and loads decreased with a high degree of statistical likelihood ("likely down" trends) over the period of record at all the modeled 


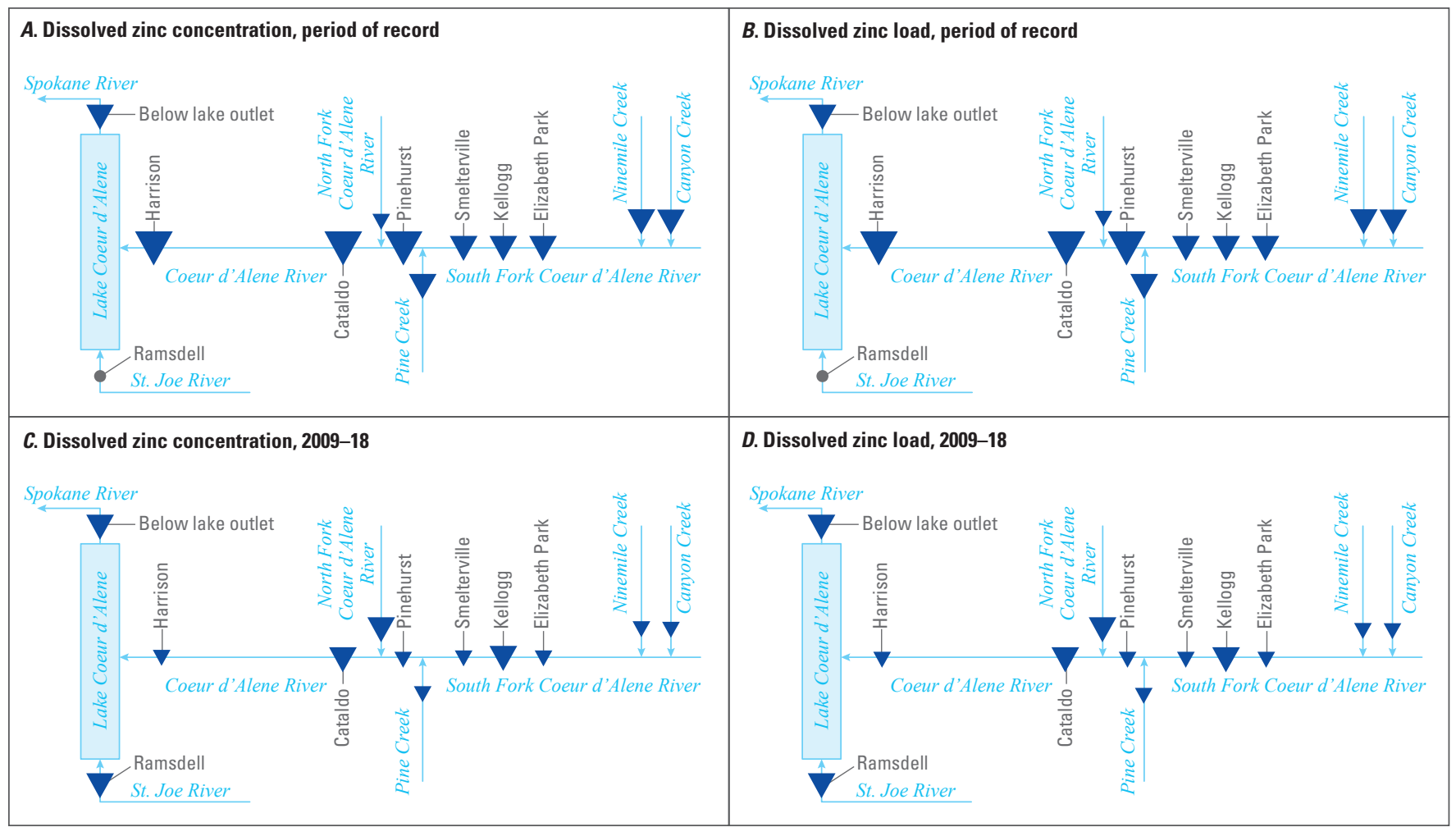

EXPLANATION

[This explanation shows all possible symbols in order to maintain consistency between this figure and similar figures in this report, but not all symbols appear in each figure. The absence of a symbol in any individual figure is intentional and means that it does not apply to that individual figure.]

Likelihood descriptor-Shown by
symbol shape and color

Figure 9. Statistical likelihood and magnitude of change in flow-normalized dissolved zinc concentrations and annual total loads over the period of record and water years 2009-18 for sites in the Spokane River watershed, northern Idaho. Sites are shown in figure 1. Statistical likelihoods are defined in table 4. Period of record is defined for each site and constituent in table 3. Diagram is not to scale.

sites (Zinsser, 2020; fig. 12). The percent decrease in concentrations varied from 26 percent $(-0.049 \mu \mathrm{g} / \mathrm{L})$ in the Spokane River below lake outlet to 67 percent $(-2.1 \mu \mathrm{g} / \mathrm{L})$ in the CDR near Cataldo. The percent load reductions varied from 25 percent (-0.31 metric tons) in the Spokane River below lake outlet to 70 percent ( -3.3 metric tons) in the CDR near Cataldo (Zinsser, 2020).

From WY 2009 to 2018, flow-normalized dissolved cadmium concentrations and loads decreased with a high degree of statistical likelihood ("likely down" trends) at all modeled sites, albeit with more modest declines than over the period of record (Zinsser, 2020; fig. 12). The decreases in concentrations ranged from 12 percent $(-1.8 \mu \mathrm{g} / \mathrm{L})$ in Ninemile Creek to 29 percent $(-0.44 \mu \mathrm{g} / \mathrm{L})$ in CDR near Cataldo. The decreases in load ranged from 12 percent (-0.25 metric tons) in CDR near Harrison to 28 percent ( -0.55 metric tons) in CDR near Cataldo (Zinsser, 2020).

The difference in load trends from earlier in the period of record to the most recent decade (fig. 11) was explored with trend slope confidence intervals (fig. 10). For most of the sites used in this analysis, the trend slopes were somewhat less steep during WYs 2009-18 than during WYs 1999-2009 (fig. 10). This decrease in trend slope suggests that remedial actions had a relatively greater impact reducing dissolved cadmium loads from WY 1999 to 2009 than during WYs 2009-18.

The trends and likelihoods for flow-normalized total cadmium concentrations and loads are markedly similar to the trends and likelihoods for dissolved cadmium (Zinsser, 


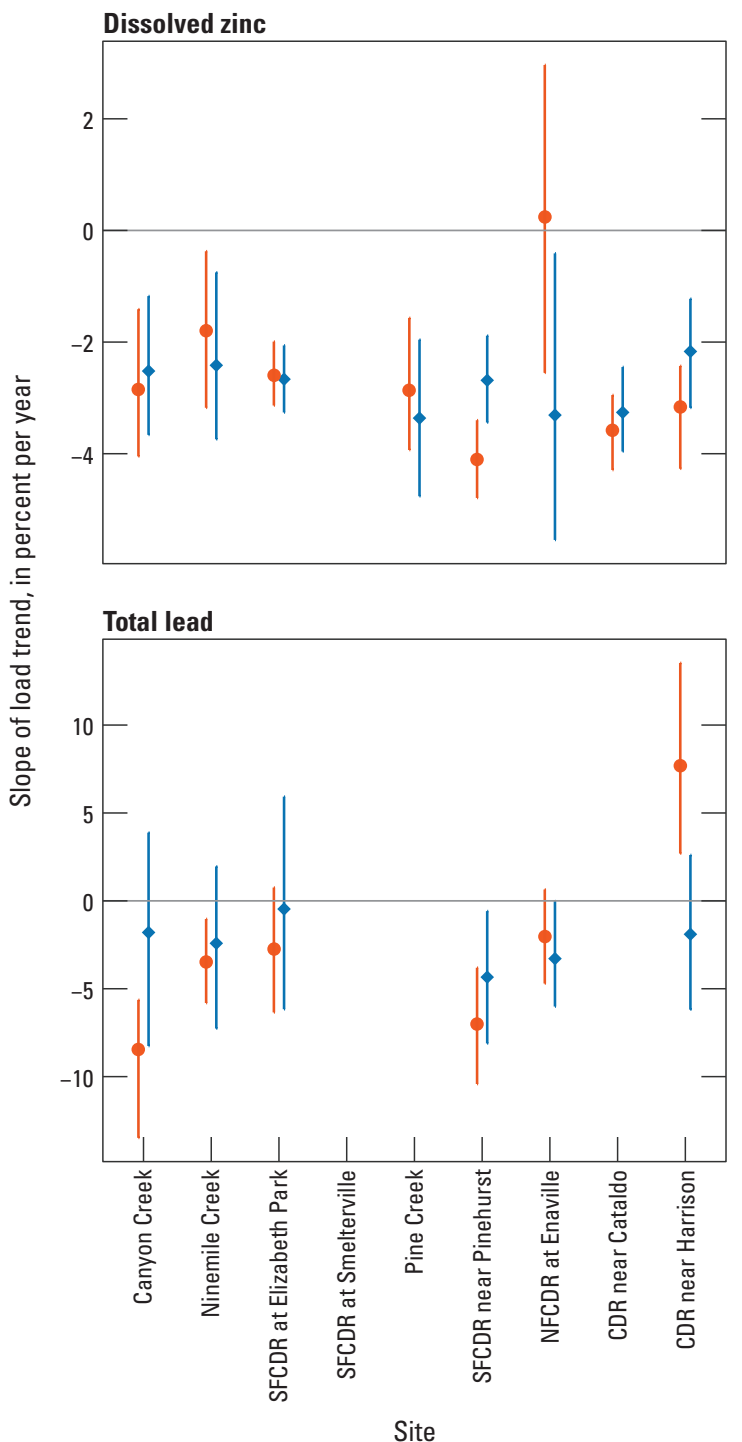

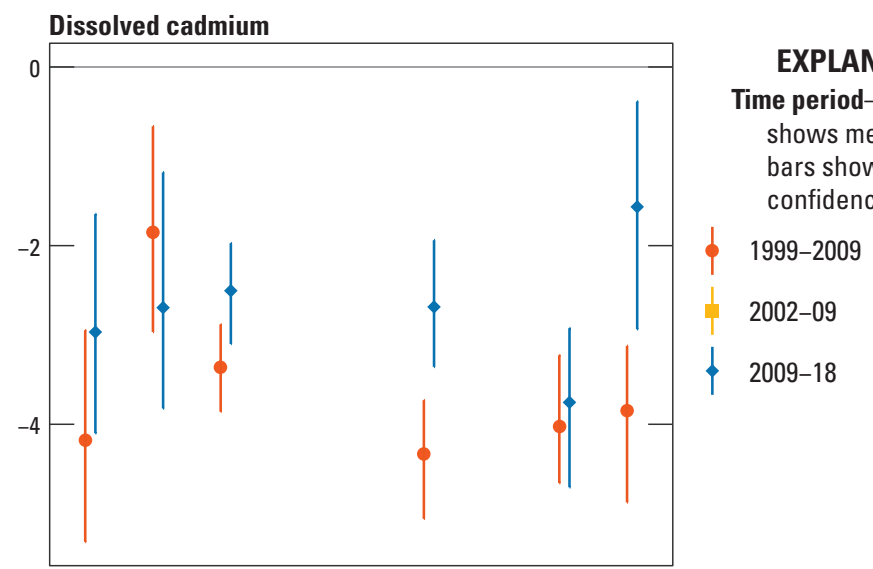

EXPLANATION

me period-Symbol shows median; vertical bars show 90 percent confidence interval

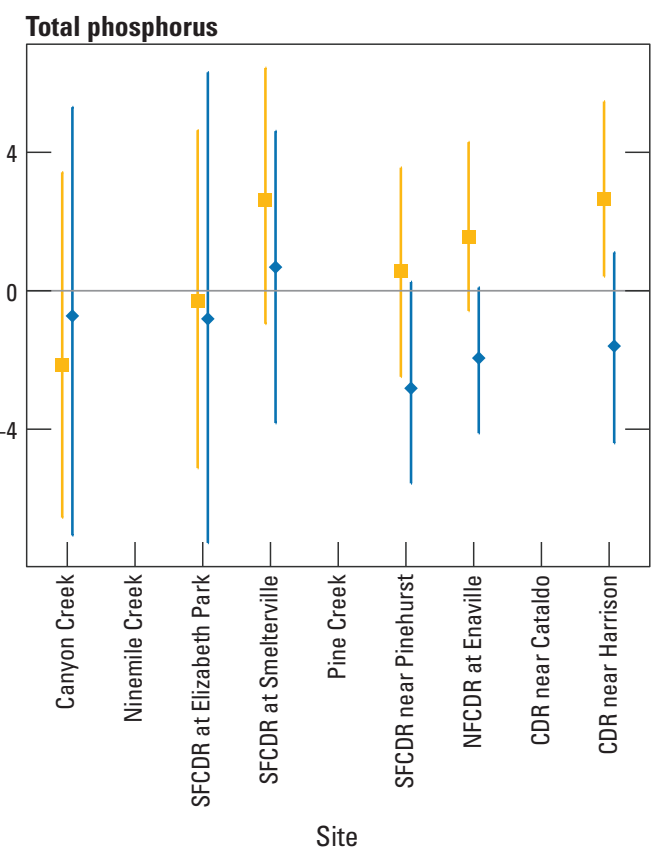

Figure 10. Change in load per year (slope of load trends) and 90 percent confidence intervals for select constituents and sites in the Spokane River watershed, northern Idaho, water years 1999-2018. Sites are shown in figure 1. Abbreviations: CDR, Coeur d'Alene River; NFCDR, North Fork Coeur d'Alene River; SFCDR, South Fork Coeur d'Alene River.

2020). This reflects the dominance of the dissolved fraction in total cadmium. One difference in the results, however, was the failure of multiple total cadmium bootstrap replicate models to converge, which led to null results for total cadmium load likelihoods in Pine Creek for the period of record (Zinsser, 2020). For Pine Creek, this lack of model convergence likely arose from a data collection gap between WYs 2004 and 2007 and the relative smallness of the dataset $(n=69$, with 9 censored values; table 3 ).

\section{Lead}

The WRTDS and WRTDS K model results indicate variable trends in total lead over the period of record. Figure 13 shows the WRTDS K annual mean concentrations and annual total loads and the WRTDS flow-normalized annual mean concentrations and annual total loads for select sites (SFCDR near Pinehurst, CDR near Harrison, and Spokane River below lake outlet; complete results are in appendix 1). Decreases in total lead concentrations and loads occurred at both SFCDR and Pinehurst and Spokane River below lake outlet over the period of record (which varies from 1990 to 2018 at SFCDR near Pinehurst to 2003-2018 at Spokane River below lake outlet), although the magnitude of the change was much greater at SFCDR near Pinehurst. Total lead concentrations and loads in CDR near Harrison had variable trends, with both increases and decreases over the period of record (fig. 13).

In the entire study area over the period of record, flownormalized concentrations of total lead decreased with a high degree of statistical likelihood ("likely down" trends) at 

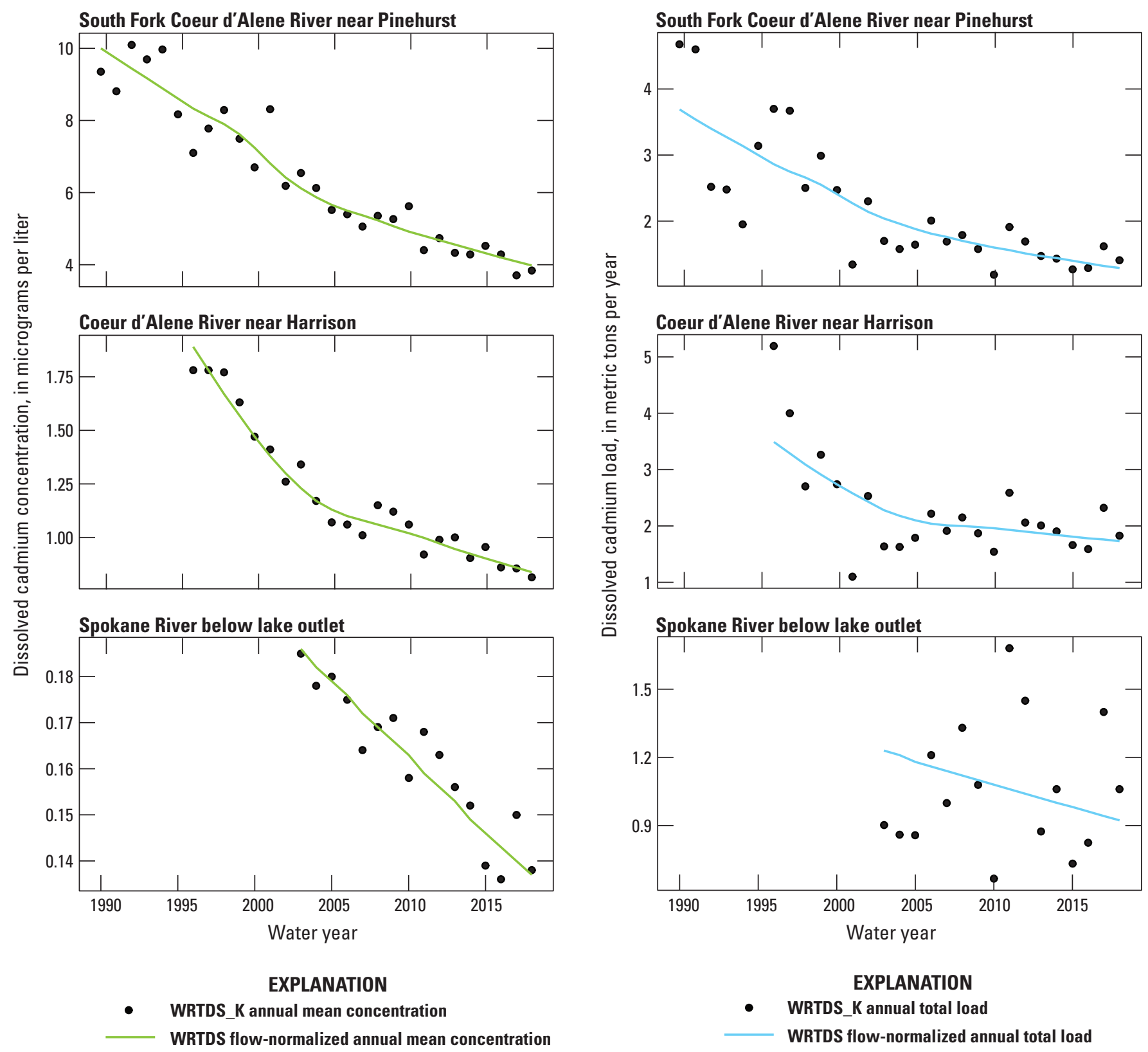

Figure 11. Dissolved cadmium annual mean concentrations and annual total loads from Weighted Regressions on Time, Discharge and Season with Kalman filtering and flow-normalized annual mean concentrations and annual total loads from Weighted Regressions on Time, Discharge and Season for select sites in the Spokane River watershed, northern Idaho, water years 1990-2018. Sites are shown in figure 1. Abbreviations: WRTDS, Weighted Regressions on Time, Discharge and Season; WRTDS_K, Weighted Regressions on Time, Discharge and Season with Kalman filtering.

most sites (Zinsser, 2020; fig. 14). The trend was "somewhat likely down" for SFCDR at Kellogg, and a downward trend was "about as likely as not" for the St. Joe River at Ramsdell (where concentrations are very low relative to the rest of study area). For sites with "likely down" trends, the decreases ranged from 25 percent $(-22 \mu \mathrm{g} / \mathrm{L})$ for CDR near Harrison to 76 percent $(-59 \mu \mathrm{g} / \mathrm{L})$ for SFCDR near Pinehurst (Zinsser, 2020). The trends were more variable for flow-normalized total lead loads. Most SFCDR sites and tributaries and the
Spokane River below lake outlet had "likely down" trends, with the percent change ranging from 32 percent (-4.5 metric tons) in the Spokane River below lake outlet to 78 percent (-86 metric tons) in the SFCDR near Pinehurst. A downward trend was "about as likely as not" for SFCDR at Kellogg, and the trend was "somewhat likely down" for the St. Joe River at Ramsdell. Notably, the total lead load trend was "somewhat likely up" in the CDR near Harrison, with a positive change of 24 percent (168 metric tons; Zinsser, 2020). 


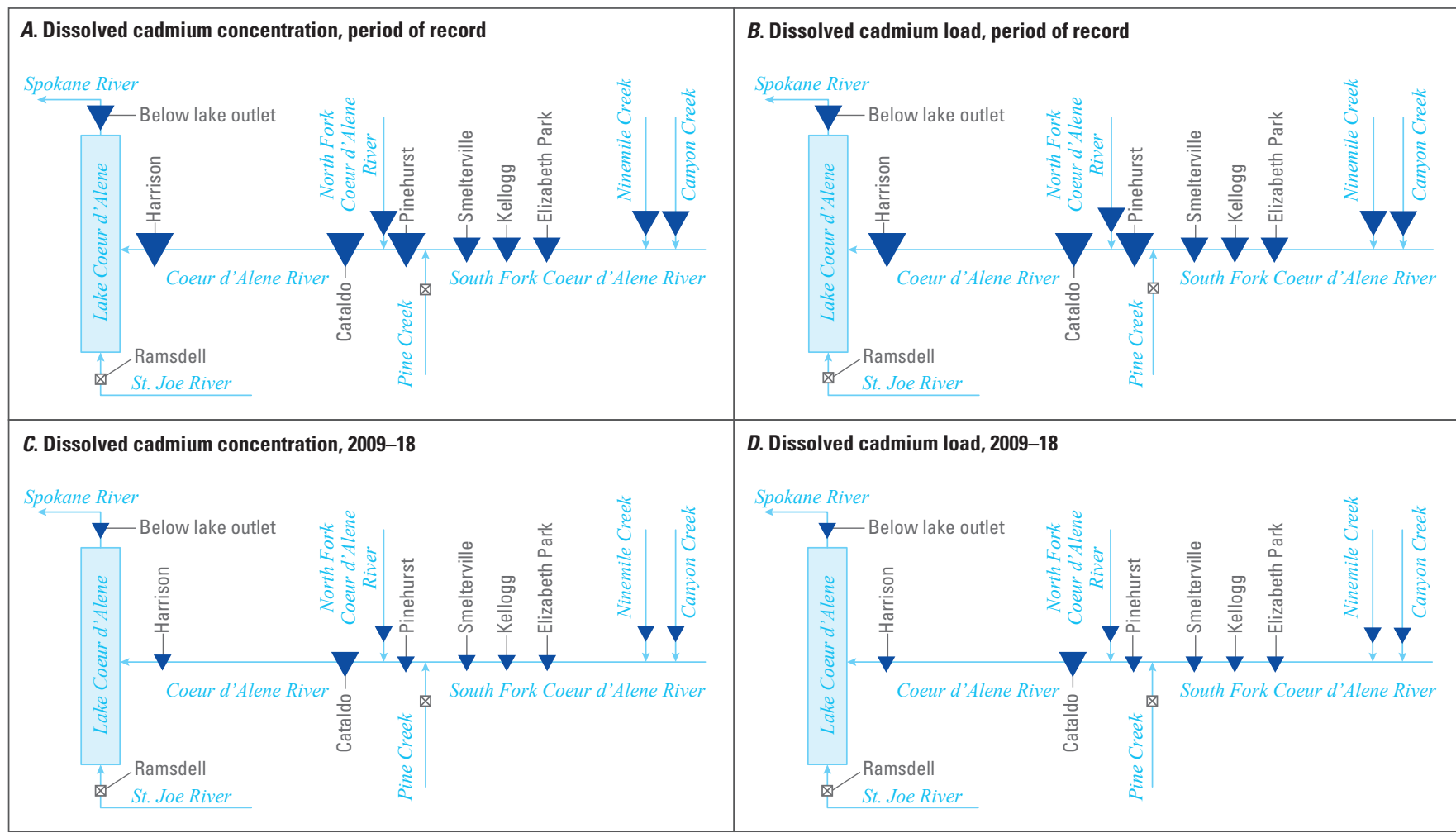

EXPLANATION

[This explanation shows all possible symbols in order to maintain consistency between this figure and similar figures in this report, but not all symbols appear in each figure. The absence of a symbo in any individual figure is intentional and means that it does not apply to that individual figure.]

$\begin{array}{ll} & \begin{array}{c}\text { Likelihood descriptor-Shown by } \\ \text { symbol shape and color }\end{array} \\ \Delta & \text { Likely up } \\ \Delta & \text { Somewhat likely up } \\ \nabla & \text { About as likely as not } \\ \nabla & \text { Somewhat likely down } \\ \nabla & \text { Likely down } \\ \boldsymbol{\nabla} & \text { No model }\end{array}$

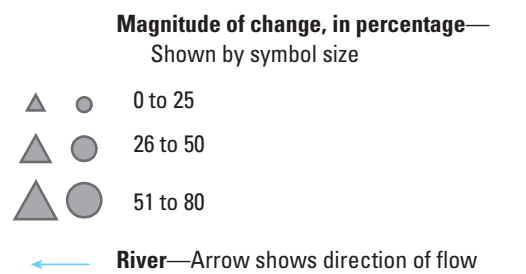

Figure 12. Statistical likelihood and magnitude of change in flow-normalized dissolved cadmium concentrations and loads over the period of record and water years 2009-18 for sites in the Spokane River watershed, northern Idaho. Sites are shown in figure 1. Statistical likelihoods are defined in table 4. Period of record is defined for each site and constituent in Table 3. Diagram is not to scale. Abbreviations: CDR, Coeur d'Alene River; NFCDR, North Fork Coeur d'Alene River; SFCDR, South Fork Coeur d'Alene River.

From WY 2009 to 2018, most SFCDR sites, the tributary sites, and the Spokane River below lake outlet had "likely down" trends in flow-normalized total lead concentrations (Zinsser, 2020; fig. 14). For sites with "likely down" trends, the concentration decreases ranged from 24 percent $(14 \mu \mathrm{g} / \mathrm{L})$ in Ninemile Creek to 47 percent $(-0.55 \mu \mathrm{g} / \mathrm{L})$ in Pine Creek. Flow-normalized total lead concentration trends were "somewhat likely down" in the NFCDR at Enaville, SFCDR at Kellogg, CDR near Harrison, and St. Joe River at Ramsdell. The decreases at these sites were generally smaller than those for the "likely down" trends, ranging from 14 percent (-0.092 $\mu \mathrm{g} / \mathrm{L})$ in the NFCDR at Enaville to 24 percent $(-6.9 \mu \mathrm{g} / \mathrm{L})$ in the SFCDR at Kellogg. For one site, SFCDR at Elizabeth Park, a downward trend was "about as likely as not". The flow-normalized total lead load trends from WY 2009 to 2018 were similarly variable. Several sites had "likely down" trends (NFCDR at Enaville, Ninemile Creek, SFCDR near Pinehurst, St. Joe River at Ramsdell and Spokane River below lake outlet). The decreases at these sites ranged from 22 percent $(-0.46$ metric tons) at Ninemile Creek to 33 percent (-12 metric tons) in SFCDR near Pinehurst. Two sites had "somewhat likely down" trends (Canyon Creek and SFCDR at Smelterville), and a downward trend was "about as likely as not" at three sites (SFCDR at Elizabeth Park, SFCDR at Kellogg and CDR near Harrison; Zinsser, 2020).

The slope confidence intervals for total lead help to illustrate differences between load trends for earlier and later time periods (fig. 10). For most of the sites used in this analysis, the 

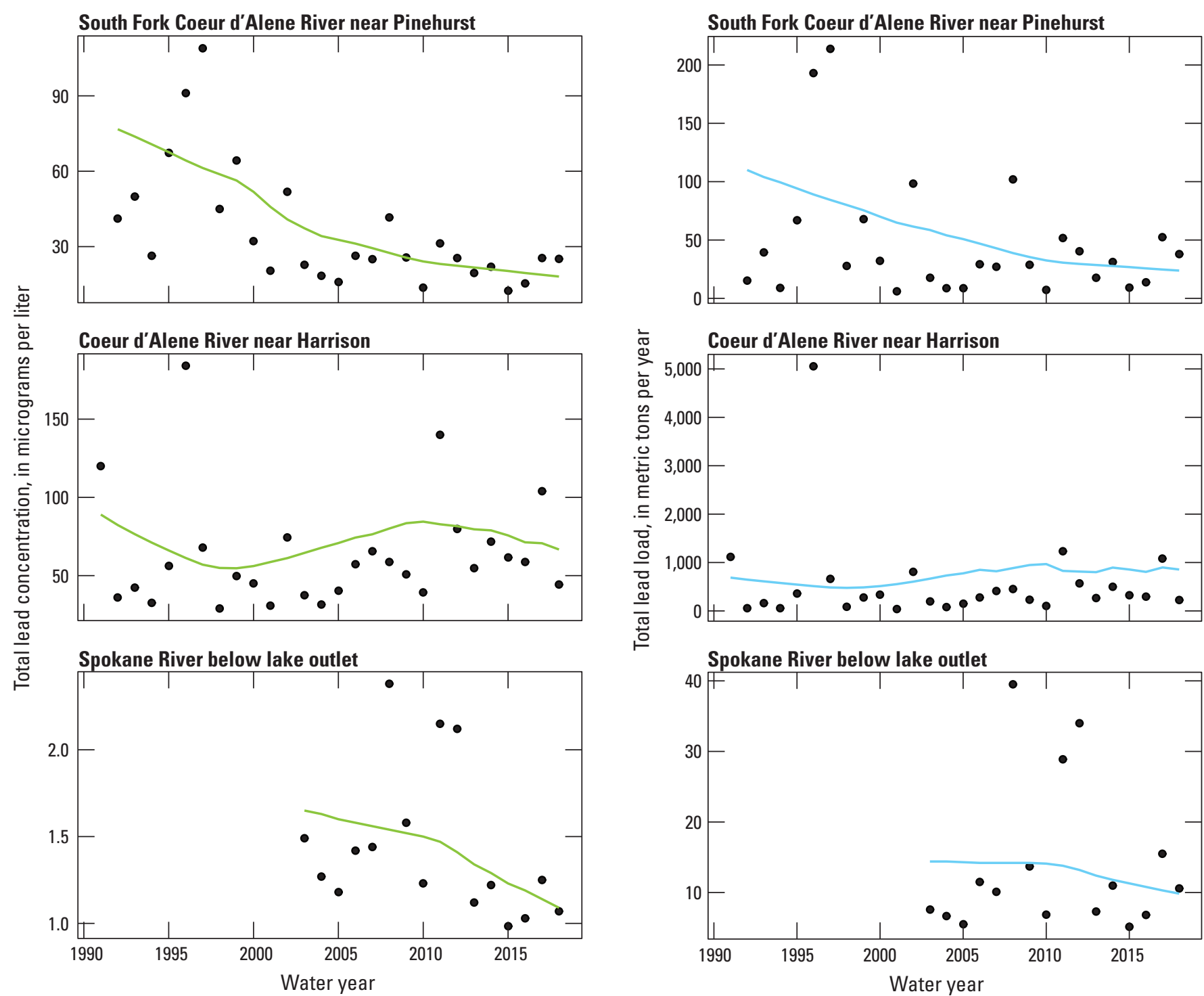

EXPLANATION

- WRTDS_K annual mean concentration

WRTDS flow-normalized annual mean concentration

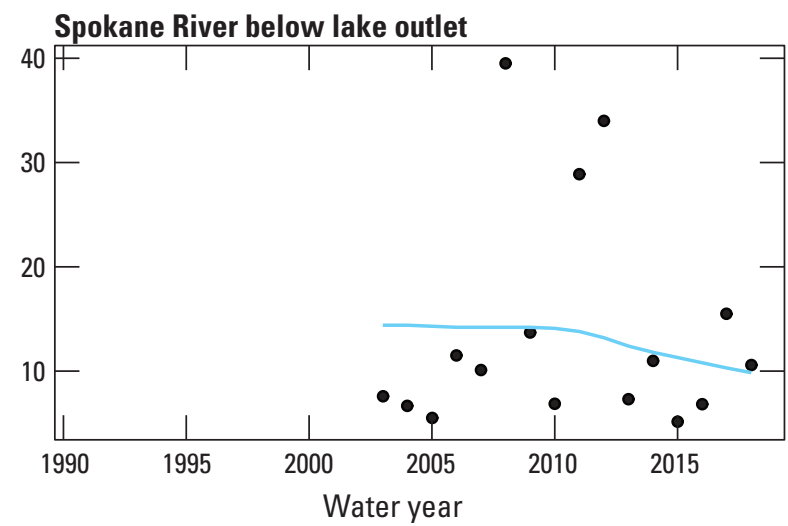

EXPLANATION

- WRTDS_K annual total load

WRTDS flow-normalized annual total load

Figure 13. Total lead annual mean concentrations and annual total loads from Weighted Regressions on Time, Discharge and Season with Kalman filtering (WRTDS_K) and flow-normalized annual mean concentrations and annual total loads from Weighted Regressions on Time, Discharge and Season (WRTDS) for select sites in the Spokane River watershed, northern Idaho, water years 1990-2018. Sites are shown in figure 1. Abbreviations: WRTDS, Weighted Regressions on Time, Discharge and Season; WRTDS_K, Weighted Regressions on Time, Discharge and Season with Kalman filtering.

trend slopes were somewhat less steep during WYs 2009-18 than during WYs 1999-2009. This suggests that remedial actions had a relatively greater impact reducing total lead loads from WY 1999 to 2009 than during WYs 2009-2018. The CDR near Harrison shows a markedly different trend though, with lead loads increasing from WY 1999 to 2009 and then decreasing (but near 0) from WYs 2009-2018 (fig. 10).
Generally, trends and likelihoods in flow-normalized dissolved lead concentrations and loads were similar to the trends for total lead (Zinsser, 2020). Most sites had "likely down" or "somewhat likely down" trends during WYs 2009-2018 and the period of record. There were a couple of exceptions. Dissolved lead concentrations and loads had "likely up" trends at St. Joe River at Ramsdell over both the period of record and WYs 2009-18. The changes in concentrations and loads 


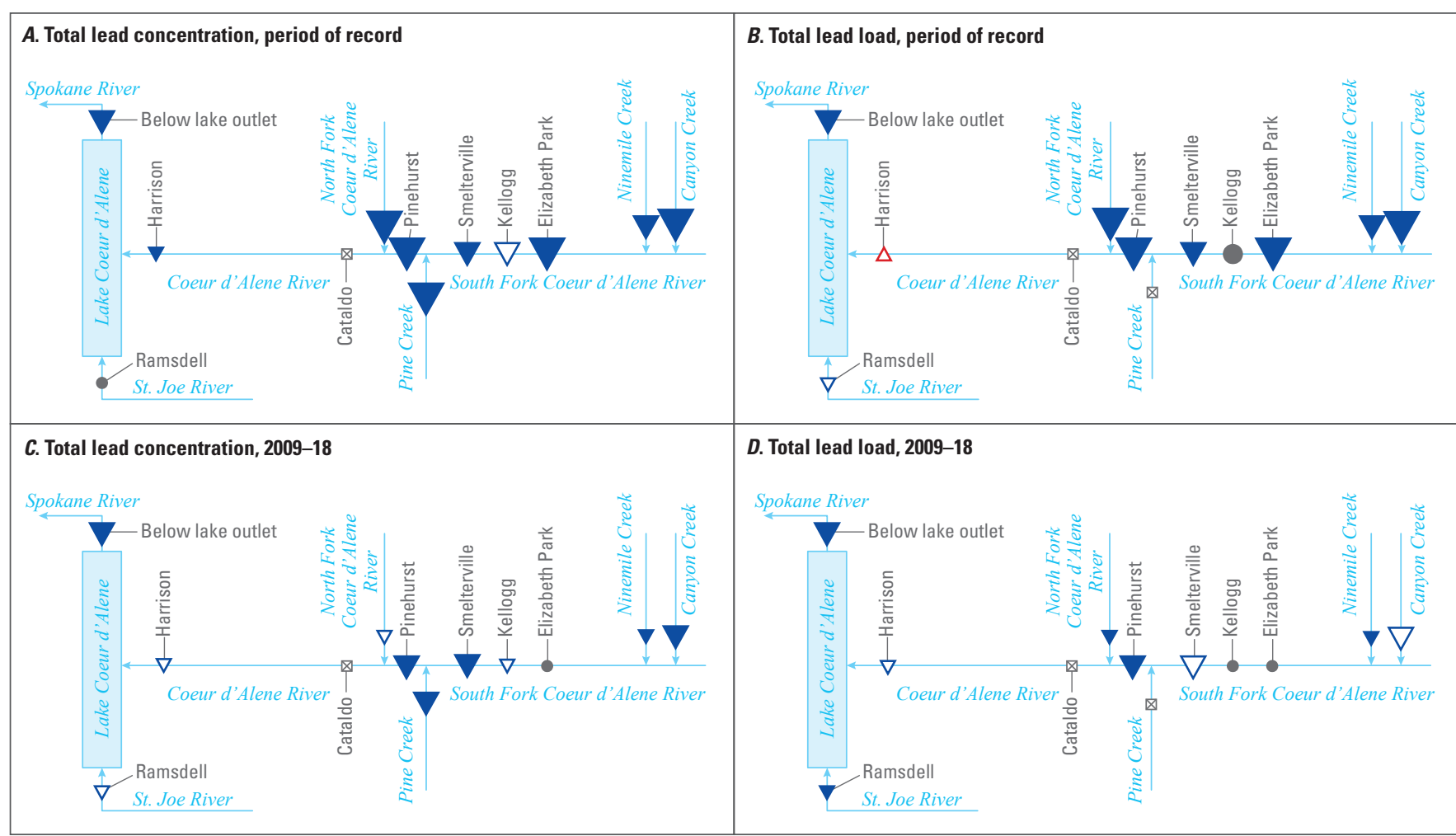

EXPLANATION

[This explanation shows all possible symbols in order to maintain consistency between this figure and similar figures in this report, but not all symbols appear in each figure. The absence of a symbol in any individual figure is intentional and means that it does not apply to that individual figure.]

\begin{tabular}{|c|c|}
\hline $\begin{array}{l}\text { Likelihood descriptor-Shown by } \\
\text { symbol shape and color }\end{array}$ & $\begin{array}{l}\text { Magnitude of change, in percentage- } \\
\text { Shown by symbol size }\end{array}$ \\
\hline Likely up & - \\
\hline Somewhat likely up & 0 to $\mathrm{Zb}$ \\
\hline About as likely as not & 26 to 50 \\
\hline Somewhat likely down & \\
\hline Likely down & 51 to 80 \\
\hline No model & River-Arrow shows direction of flow \\
\hline
\end{tabular}

Figure 14. Statistical likelihood and magnitude of change in flow-normalized total lead concentrations and loads over the period of record and water years 2009-18 for sites in the Spokane River watershed, northern Idaho. Sites are shown in figure 1. Statistical likelihoods are defined in table 4. Period of record is defined for each site and constituent in Table 3. Diagram is not to scale.

were small in absolute terms as concentrations at this site were still quite low $(0.114 \mu \mathrm{g} / \mathrm{L}$; table 8$)$, overlapped with lead contamination in blanks (median $0.074 \mu \mathrm{g} / \mathrm{L}$ to maximum $4.82 \mu \mathrm{g} / \mathrm{L}$; table 5), and were well below the dissolved lead AWQC (table 7). Nonetheless, the load change was 42 percent (0.1 metric tons) during WYs 2009-18 and 66 percent (0.14 metric tons) over the period of record. Dissolved lead loads in the NFCDR at Enaville also have increasing trends over the period of record (40 percent, "likely up") and WYs 2009-18 (23 percent, "somewhat likely up"). Similar to the St. Joe River at Ramsdell, although these trends were large on a relative basis, the actual dissolved lead concentrations are still quite low and exceed AWQC only rarely during high streamflow events. Finally, there are small, "somewhat likely up" trends in dissolved lead concentrations and loads in Spokane River below lake outlet over the period of record, but trends in WYs 2009-18 were "about as likely as not" (Zinsser, 2020). As discussed in the "Quality Control Samples" section, there was some evidence of filter contamination for dissolved lead in low-concentration samples that may be affecting these trends, but data were retained in these analyses to be as conservative as possible in reporting potentially real environmental trends. One line of evidence for these trends reflecting actual environmental change was that bigger increases were observed over the period of record than in WYs 2009-18, but filter contamination issues were only identified in WYs 2011 and WYs 2017-18. 


\section{Nutrients}

The WRTDS and WRTDS_K model results indicate variable trends in total phosphorus over the period of record. Figure 15 shows the WRTDS_K annual mean concentrations and annual total loads and the WRTDS flow-normalized annual mean concentrations and annual total loads for select sites (SFCDR near Pinehurst, CDR near Harrison and Spokane River below lake outlet; complete results are in appendix 1). Over the period of record, increases in total phosphorus concentrations and loads occurred at SFCDR and Pinehurst and CDR near Harrison through approximately 2010, followed by decreases. Decreases in the Spokane River below lake outlet occurred throughout the period of record, although the record extended only from WY 2003 to 2018, whereas records from the other two sites extended from the 1990s to 2018 (fig. 15).

In the entire study area, trends in total phosphorus for flow-normalized concentrations and loads over the period of record were variable (Zinsser, 2020; fig. 16). Two sites, SFCDR near Pinehurst and CDR near Harrison, had "likely up" trends in total phosphorus concentration of 51 percent $(13 \mu \mathrm{g} / \mathrm{L})$ and 19 percent $(2.7 \mu \mathrm{g} / \mathrm{L})$, respectively. One site, SFCDR at Smelterville, had a "somewhat likely up" trend of 22 percent $(6.3 \mu \mathrm{g} / \mathrm{L})$. One site, Spokane River below lake outlet, had a "likely down" trend of 25 percent $(-1.9 \mu \mathrm{g} / \mathrm{L})$. Canyon Creek and SFCDR at Kellogg had "somewhat likely down" trends, and there were multiple sites where downward trends were "about as likely as not" (SFCDR at Elizabeth Park, NFCDR at Enaville and St. Joe River at Ramsdell). The flow-normalized load trends were similarly variable. One site, SFCDR near Pinehurst, had a "likely up" trend in total phosphorus loads of 68 percent ( 8 metric tons). SFCDR at Smelterville and CDR near Harrison, had "somewhat likely up" trends of 25 percent (3.1 metric tons) and 11 percent (6.7 metric tons), respectively. One site, Spokane River below lake outlet, had a "likely down" trend of 20 percent (-9.6 metric tons). St. Joe River at Ramsdell had a "somewhat likely down" trend (17 percent, -16 metric tons). Trends at the remaining sites were "about as likely as not." However, it is critical to note that the period of record varied widely, and therefore direct comparison of trends was hampered by the mismatch between record lengths due to sparse underlying data. The SFCDR near Pinehurst model was by far the longest, encompassing WYs 1990-2018; the records at all the other sites were substantially shorter, with start dates ranging between WY 1998 (NFCDR at Enaville) and WY 2006 (SFCDR at Kellogg; Zinsser, 2020).

Contrary to the period of record, the total phosphorus trends in flow-normalized concentrations and loads during WYs 2009-2018 were either uncertain or down at all sites (Zinsser, 2020; fig. 16). This is logical given the shape (non-monotonic) of the WRTDS results (fig. 16) and points to one of the benefits of using the WRTDS approach because other models (for example, LOADEST) cannot detect nonmonotonic trends. Four sites (NFCDR at Enaville, Canyon Creek, SFCDR near Pinehurst, and Spokane River below lake outlet) had "likely down" trends in total phosphorus concentrations, with the decreases ranging from 12 percent $(-5.1 \mu \mathrm{g} / \mathrm{L}$ and $-0.79 \mu \mathrm{g} / \mathrm{L})$ at SFCDR near Pinehurst and Spokane River below lake outlet, respectively) to 23 percent $(-1.4 \mu \mathrm{g} / \mathrm{L})$ at Canyon Creek. Two sites had "somewhat likely down" trends (SFCDR at Kellogg and St. Joe River at Ramsdell). Downward trends in total phosphorus concentrations were "about as likely as not" for the remaining sites (SFCDR at Elizabeth Park, SFCDR at Smelterville, and CDR near Harrison). The flow-normalized load trends were similar. Three sites (NFCDR at Enaville, SFCDR near Pinehurst, and St. Joe River at Ramsdell) had "likely down" trends, with load decreases ranging from 15 percent (-14 metric tons) at St. Joe River at Ramsdell to 19 percent (-4.8 metric tons) at SFCDR near Pinehurst. Two sites, CDR near Harrison and Spokane River below lake outlet, had modest "somewhat likely down" trends with decreases around 10 percent. At the remainder of the sites, downward trends were "about as likely as not" (Zinsser, 2020).

The slope confidence intervals for the total phosphorus load trends help to illustrate differences between earlier and later time periods by standardizing the timeframe for comparison (fig. 10). Tributary and upstream sites (Canyon Creek, Ninemile Creek and SFCDR at Elizabeth Park) had slopes near 0 for both WYs 2002-09 and WYs 2009-18. Slopes were positive in WYs 2002-09 and negative in WYs2009-18 for downstream sites (SFCDR near Pinehurst, NFCDR at Enaville and SCDR near Harrison; fig. 10). This reversal in trend direction suggests that some mechanism(s) increased total phosphorus loading at downstream sites during WYs 2002-09, and then either the same or different mechanism(s) decreased total phosphorus loading at these same sites during WYs 2009-18.

Modeling results for orthophosphate were limited by a high number of censored samples at all sites; consequently, WRTDS and associated likelihood modeling could only be completed for three sites-SFCDR near Pinehurst, CDR near Harrison, and St. Joe River at Ramsdell (table 3; Zinsser, 2020). Over the period of record, flow-normalized orthophosphate concentrations were "likely up" in SFCDR near Pinehurst (55 percent, $5.5 \mu \mathrm{g} / \mathrm{L}$ ) and CDR near Harrison (78 percent, $1.5 \mu \mathrm{g} / \mathrm{L})$. Flow-normalized orthophosphate loads were also up at these sites, 40 percent (1.6 metric tons) and 81 percent (4.3 metric tons), respectively. At St. Joe River at Ramsdell, a trend in concentrations was "about as likely as not" and a trend in loads was "somewhat likely up" (18 percent, 3 metric tons; Zinsser, 2020).

However, trends for WYs 2009-18 were largely opposite the period of record trends (Zinsser, 2020). At CDR near Harrison, flow normalized orthophosphate concentrations and loads were "likely down" with a 23 percent decrease $(-1.0$ $\mu \mathrm{g} / \mathrm{L})$ in concentration and a 13 percent decrease $(-1.4$ metric tons) in load. At SFCDR near Pinehurst, concentrations were "somewhat likely down" (4.1 percent, $-0.61 \mu \mathrm{g} / \mathrm{L}$ ), although loads were "somewhat likely up" (13 percent, 0.65 metric tons). Trends in flow-normalized orthophosphate concentration and loads were "about as likely as not" during WYs 2009-2018 at St. Joe River at Ramsdell (Zinsser, 2020). 
South Fork Coeur d'Alene River near Pinehurst

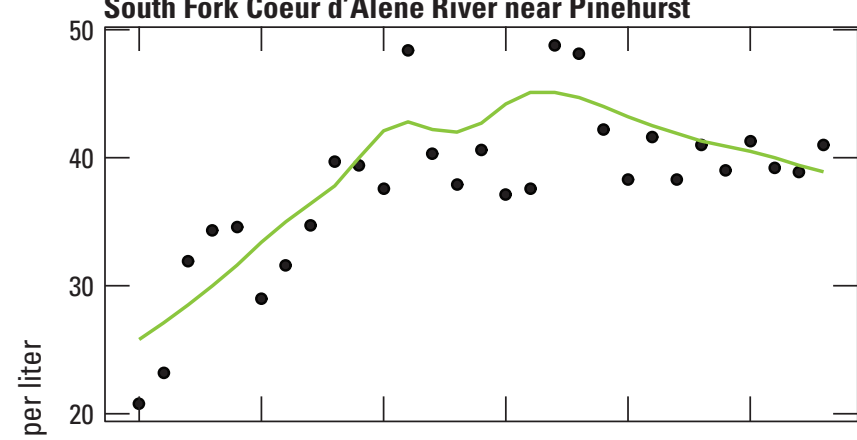

Coeur d'Alene River near Harrison

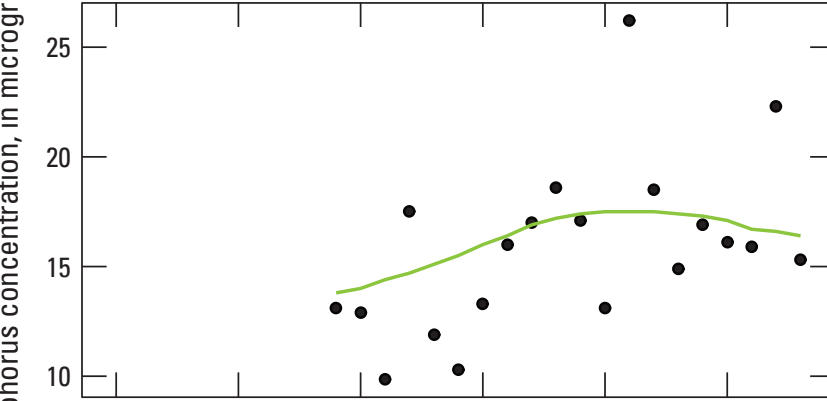

들 Spokane River below lake outlet

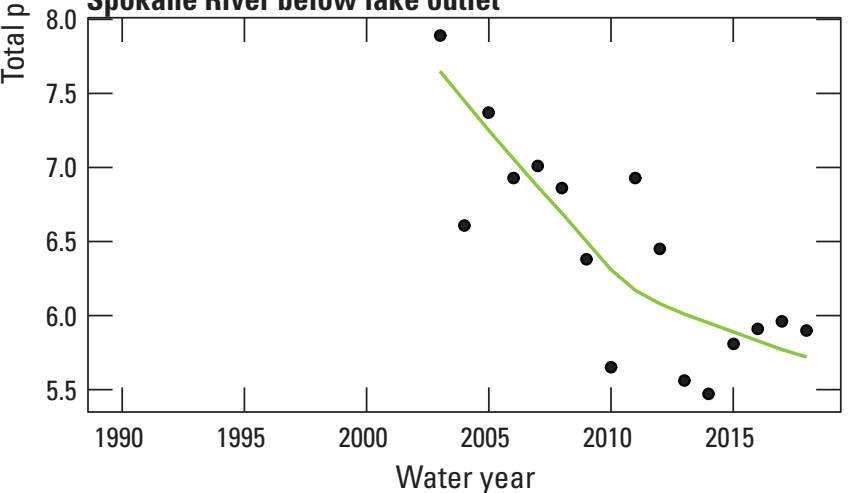

EXPLANATION

- WRTDS $K$ annual mean concentration

WRTDS flow-normalized annual mean concentration

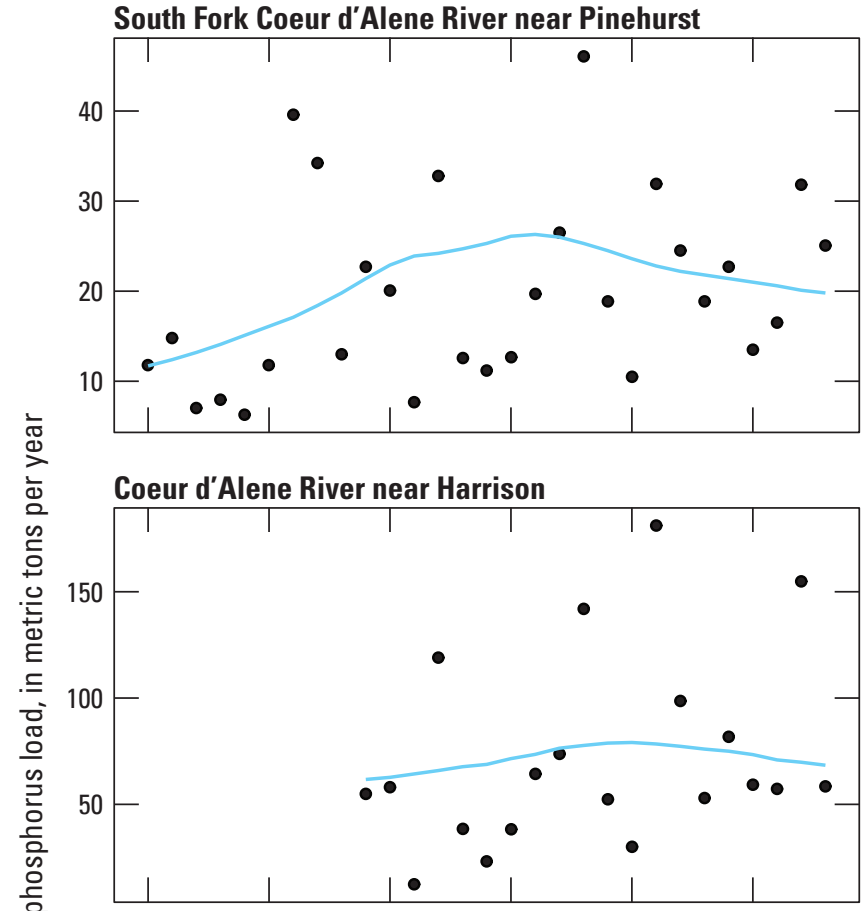

Spokane River below lake outlet

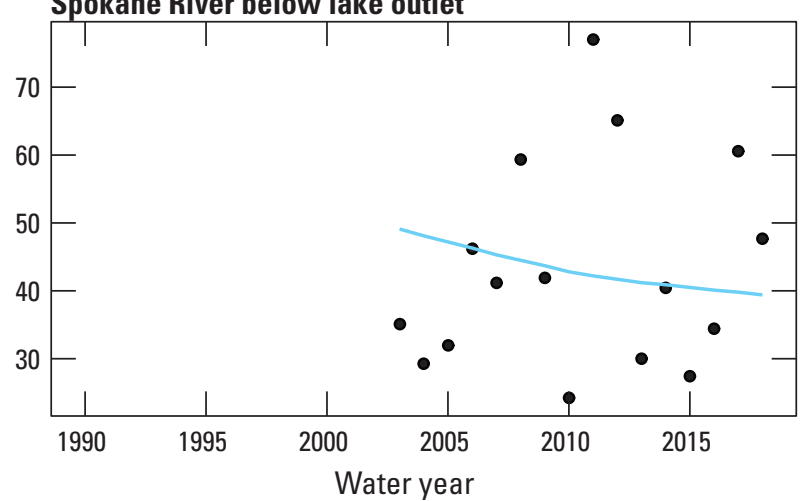

EXPLANATION

- WRTDS_K annual total load

WRTDS flow-normalized annual total load

Figure 15. Total phosphorus annual mean concentrations and annual total loads from Weighted Regressions on Time, Discharge and Season with Kalman filtering (WRTDS_K) and flow-normalized annual mean concentrations and annual total loads from Weighted Regressions on Time, Discharge and Season (WRTDS) for select sites in the Spokane River watershed, northern Idaho, water years 1990-2018. Sites are shown in figure 1. Abbreviations: WRTDS, Weighted Regressions on Time, Discharge and Season; WRTDS_K, Weighted Regressions on Time, Discharge and Season with Kalman filtering.

Changes in orthophosphate concentrations and loads were inconsistently related to changes in total phosphorus loads and concentrations. For example, although total phosphorus and orthophosphate concentrations and loads all increased at SFCDR near Pinehurst and CDR near Harrison over the period of record, increases in orthophosphate concentrations were equal to only about half of the total phosphorus concentration increases at both sites, and orthophosphate load increases were equal to a lesser fraction of the load increases. The relationships were even less consistent during WYs 2009-18, with changes in orthophosphate concentration and load at SFCDR near Pinehurst equal to only a small fraction (12-14 percent) of the total phosphorus changes, and orthophosphate loads were trending upwards while total phosphorus loads were trending down. At CDR near Harrison, change in orthophosphate concentration was equal to change in total phosphorus concentration, but the trend was "about as likely as not." The likely decrease in orthophosphate load was equal to only 


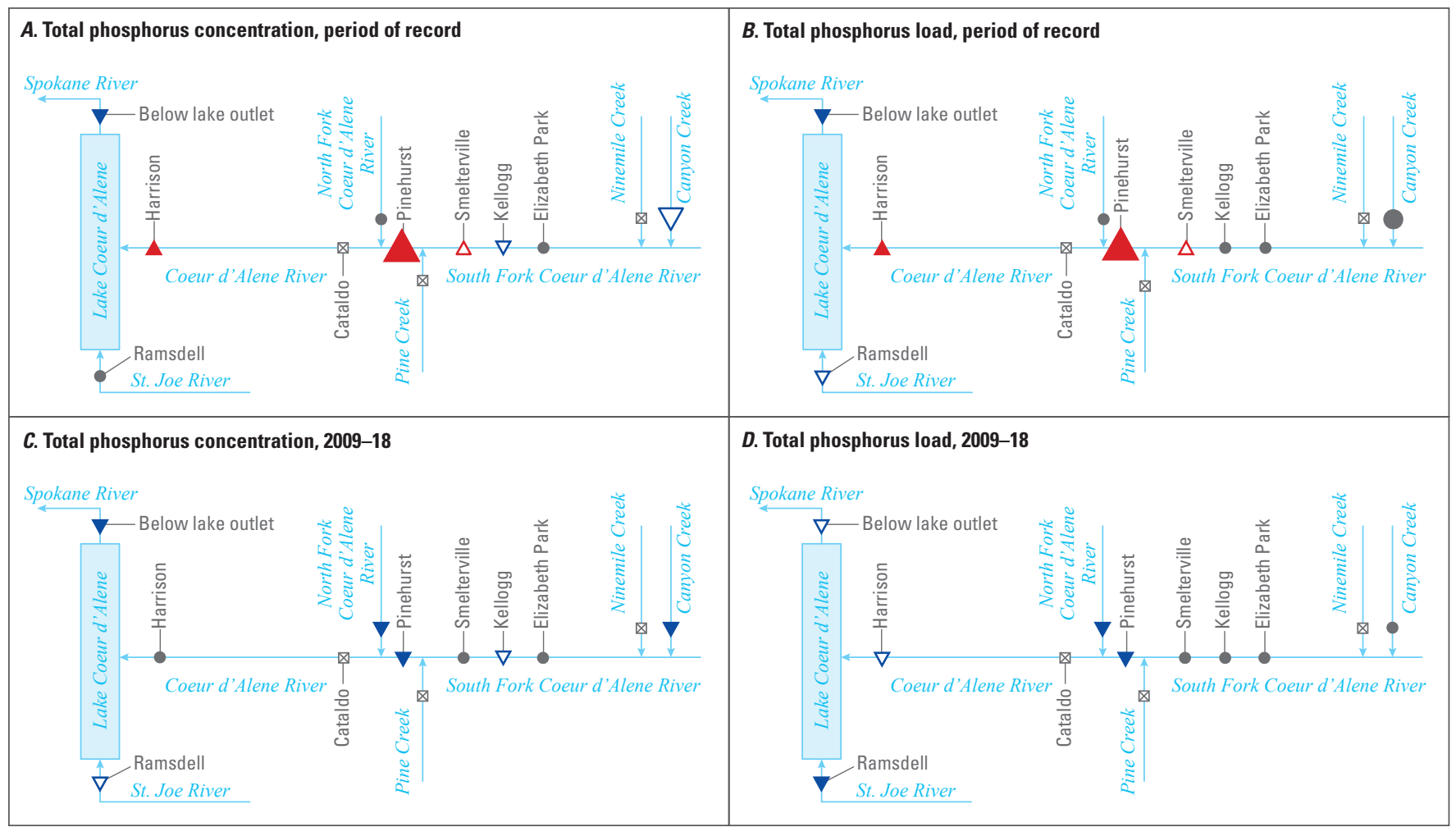

EXPLANATION

[This explanation shows all possible symbols in order to maintain consistency between this figure and similar figures in this report, but not all symbols appear in each figure. The absence of a symbo in any individual figure is intentional and means that it does not apply to that individual figure.]

$\begin{array}{ll} & \begin{array}{c}\text { Likelihood descriptor-Shown by } \\ \text { symbol shape and color }\end{array} \\ \Delta & \text { Likely up } \\ \Delta & \text { Somewhat likely up } \\ \nabla & \text { About as likely as not } \\ \nabla & \text { Somewhat likely down } \\ \nabla & \text { Likely down } \\ \nabla & \text { No model }\end{array}$

$\begin{gathered}\text { Magnitude of change, in percentage- } \\ \text { Shown by symbol size }\end{gathered}$
$\Delta \quad 0$ to 25

$\quad$ River-Arrow shows direction of flow

Figure 16. Statistical likelihood and magnitude of change in flow-normalized total phosphorus concentrations and loads over the period of record and water years 2009-18 for sites in the Spokane River watershed, northern Idaho. Sites are shown in figure 1. Statistical likelihoods are defined in table 4. Period of record is defined for each site and constituent in Table 3 . Diagram is not to scale.

10 percent of the somewhat likely decrease in total phosphorus load. Thus, although the relationships between total phosphorus and orthophosphate changes in the study area were complex, changes in orthophosphate concentrations and loads were not consistently driving the changes in total phosphorus concentrations and loads.

Total nitrogen models and trend analyses were limited by the high number of censored values and the fact that there was no systematic total nitrogen sampling in the study area before WY 2003. For the seven sites with model results (table 3; Zinsser, 2020), flow-normalized total nitrogen concentration trends were "likely down" during both the period of record and WYs 2009-18 at all but St. Joe River at Ramsdell, which was "somewhat likely down" over the period of record. Decreases in total nitrogen concentration during the period of record ranged from 16 percent $(-53 \mu \mathrm{g} / \mathrm{L})$ at SFCDR near Pinehurst to 44 percent at NFCDR at Enaville $(-33 \mu \mathrm{g} / \mathrm{L})$ and Spokane River below lake outlet $(-61 \mu \mathrm{g} / \mathrm{L})$. Flow-normalized total nitrogen load trends were "likely down" during both the period of record and WYs 2009-18 at all but two sites, SFCDR at Smelterville and SFCDR near Pinehurst, which were "somewhat likely down" during the period of record. Total nitrogen load decreases during the period of record ranged from 12 percent ( -15 metric tons) at SFCDR near Pinehurst to 41 percent ( -333 metric tons) at the Spokane River below lake outlet (Zinsser, 2020). 


\section{Spatial Patterns in Load Sources}

\section{South Fork Coeur d'Alene River}

Thus far, discussion of the modeling results has focused on flow-normalized concentrations and loads, which are wellsuited for identifying long-term trends. However, looking at year-to-year variations in the estimated loads and the incremental loads from upstream to downstream can be helpful for identifying mechanisms of transport, evaluating the relative load contributions from different source areas, and determining how these may or may not vary on a year-to-year basis. To this end, incremental loads for the SFCDR and main-stem CDR were calculated using the WRTDS_K annual total load estimates and are shown in figures 17 and 18. An incremental load represents the load added to a river in an upstream-todownstream reach that ends with a sampling site. This was calculated by subtraction; the upstream site load (if presentsome reaches start in headwaters) was subtracted from the downstream site load. Negative loads indicate that a constituent had a net loss in a reach, which could occur through deposition, biological uptake, adsorption, losses to groundwater, or by other processes. Also note that because the period of record necessarily varies by site (see table 3 ), incremental loads for each constituent were calculated to include as many sites as possible for as long as possible. Thus, not all sites were used for each constituent and longer records were truncated in some case for comparability across sites. Additionally, some constituents (for example, nitrogen and orthophosphate) have fewer increments based on lack of availability of underlying data.

Figure 17 shows incremental loads in the SFCDR for each constituent. Some general observations can be made. As total and dissolved cadmium and zinc loads have decreased over time, the proportional load from each site has remained similar. That is, because metal loads have decreased at each site, the relative load contribution of each reach to the overall SFCDR has remained about the same although the absolute loads have decreased. For total and dissolved zinc and cadmium, the overall biggest contributing segment to the SFCDR loads was the SFCDR between Elizabeth Park and Pinehurst. Dissolved lead losses occurred in most years in the SFCDR reach between the confluence of Canyon and Ninemile Creeks with the SFCDR at Elizabeth Park. This reach was also the biggest contributor to total lead loads in most years. Total metals loads were biggest during high streamflow years, including WYs 2007, 2008, 2011, and 2017, but dissolved metal loads were less affected by high streamflow years (fig. 17).

The contribution of different SFCDR reaches to the total phosphorus load at SFCDR near Pinehurst varies by year (fig. 17). Generally, the SFCDR above Elizabeth Park (which includes about two thirds of the total watershed area), the reach between Elizabeth Park and Smelterville (where the Central Impoundment Area is located), and the reach between Smelterville and Pinehurst (where the Smelterville and Page wastewater treatment facilities are located) each contribute roughly one third of the total phosphorus load, but this varies by water year. Total phosphorus loads were biggest during high streamflow years such as WYs 2002, 2008, 2011, and 2017 , but these years were not associated with consistently bigger contributions from any particular reach. This lack of consistency suggests that runoff-associated sources can be important to each of these reaches during a high streamflow year but are not necessarily important during every high streamflow year. However, the SFCDR above Elizabeth Park consistently contributed relatively lower total phosphorus loads during low streamflow years, while the Elizabeth Park to Smelterville and Smelterville to Pinehurst reaches contributed more. This pattern is consistent with expected phosphorus loads from the Central Impoundment Area and the wastewater treatment facilities, both of which would be expected to contribute relatively steady total phosphorus loads year-round and year-to-year. Total nitrogen loads could only be calculated for a few sites on the SFCDR. Generally, about half of the total nitrogen load was from the SFCDR above Elizabeth Park, and the other half came from the reach between Smelterville and Pinehurst (fig. 17).

\section{Coeur d'Alene River}

The relative contributions of the NFCDR, SFCDR, and main-stem CDR to the total loads in the CDR near Harrison are shown in figure 18. Despite contributing about 70 percent of the streamflow to the CDR, the NFCDR contributed only minor metal loads (less than 10 percent). The SFCDR has been the dominant source of dissolved zinc and cadmium (more than 50 percent) throughout the period of record, but the proportion of these loads that the CDR main stem contributes has increased over time. Note that the dissolved zinc and cadmium loads from the main-stem CDR are not increasing; they are simply proportionally more important to the total load at CDR near Harrison as loads from the SFCDR decrease. In contrast, the SFCDR was the dominant source of total zinc and cadmium until approximately WY 2005. Since then, the CDR main stem has contributed more than 50 percent of the total zinc and cadmium loads in many water years. The CDR main stem remained the dominant source of total and dissolved lead, generally contributing greater than 75 percent of the total load. While the SFCDR was a significant source of the total lead load (greater than 25 percent) in some low water years prior to WY 2000, its contribution has decreased since then (fig. 18).

Although the NFCDR likely contributes some orthophosphate load to the CDR, there were too many censored values to construct a model for this parameter at this site. So, within this analysis, the load from the NFCDR was 0 (fig. 18). Of the measurable orthophosphate loads, about half derive from the SFCDR and about half from the main-stem CDR, with contributions from the main-stem CDR tending to be larger during high streamflow years (fig. 18). The NFCDR contributed about half of the total phosphorus and total nitrogen loads as measured at CDR near Harrison, on average, while the SFCDR contributed about 25-30 percent of the total phosphorus and total nitrogen loads, respectively. On average, the remainder, 


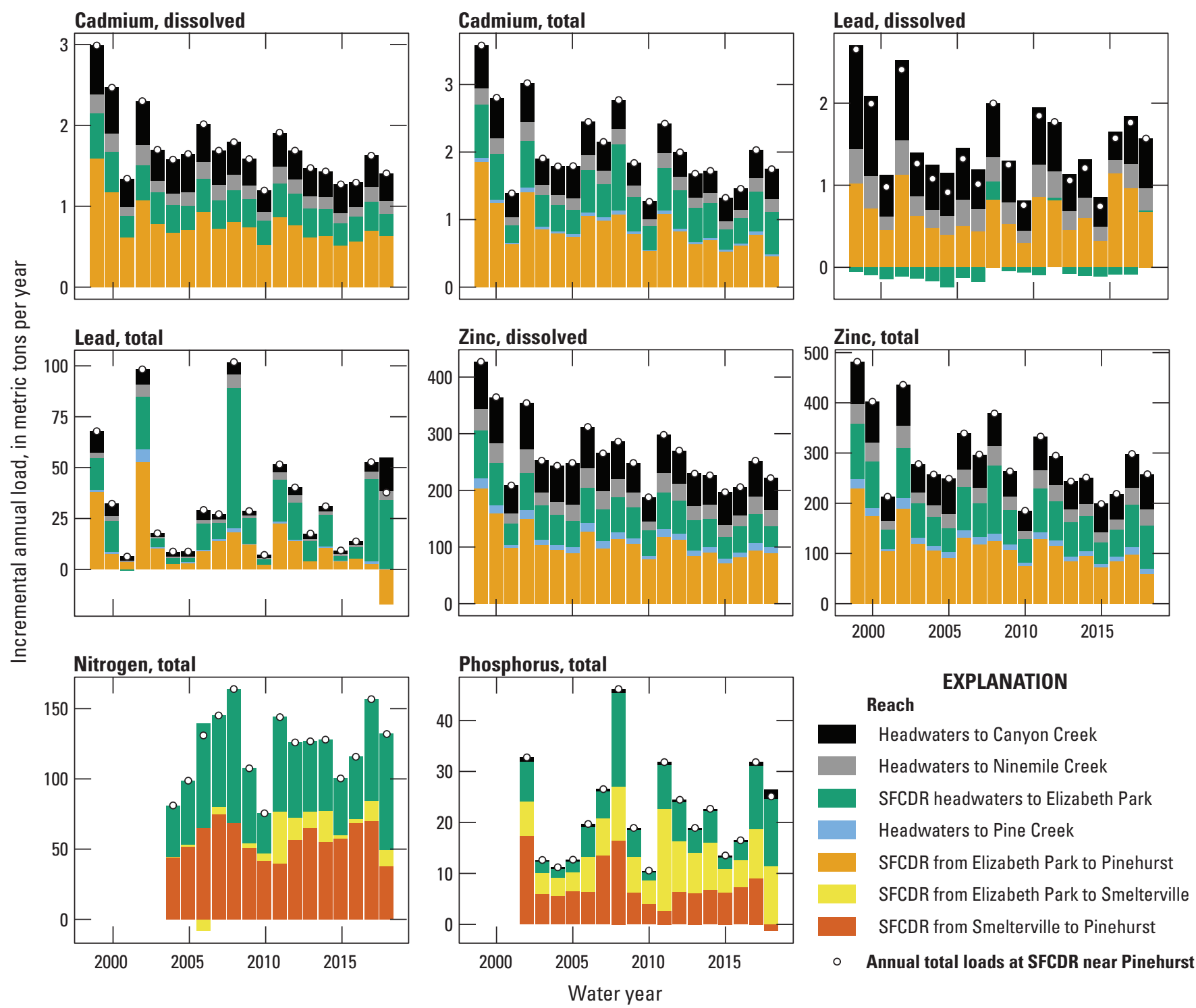

Figure 17. Incremental annual total loads for sites in the South Fork Coeur d'Alene River (SFCDR), northern Idaho, water years 1999-2018. Load estimates were not available for all sites and constituents for every year. Annual total loads at the downstream-most SFCDR site (SFCDR near Pinehurst) are shown with dots.

about 20-25 percent to the total nitrogen and total phosphorus loads, respectively, were gained in the main-stem CDR. However, substantially larger portions of the total phosphorus load (up to half) were contributed by the main-stem CDR during high streamflow years such as 2011 and 2017 (fig. 18).

\section{Coeur d'Alene Lake}

The relative load contributions of the CDR and the St. Joe River to Coeur d'Alene Lake, and the load out of Coeur d'Alene Lake to the Spokane River, are shown in figure 19. Note that for metals, it is a reasonable assumption that loads from the CDR and St. Joe River account for the essentially all-metal loading to the lake. For nutrients, however, there are likely additional loads from smaller tributaries and the lakeshore itself that are not accounted for in this analysis; thus, the nutrient loads into and out of the lake represented here do not represent a complete mass balance. Likewise, neither the metals nor the nutrient comparisons of loads in and loads out account for in-lake processes. Virtually all the metal loads to Coeur d'Alene Lake came from the SFCDR. The load out of Coeur d'Alene Lake via the Spokane River was generally equivalent to most of the dissolved zinc load and approximately half of the dissolved cadmium load entering the lake, with more exported during higher streamflow years. Generally, an amount equivalent to about 50-75 percent of the total zinc and cadmium loads into Coeur d'Alene Lake remained there; this seemed to be relatively insensitive to interannual 


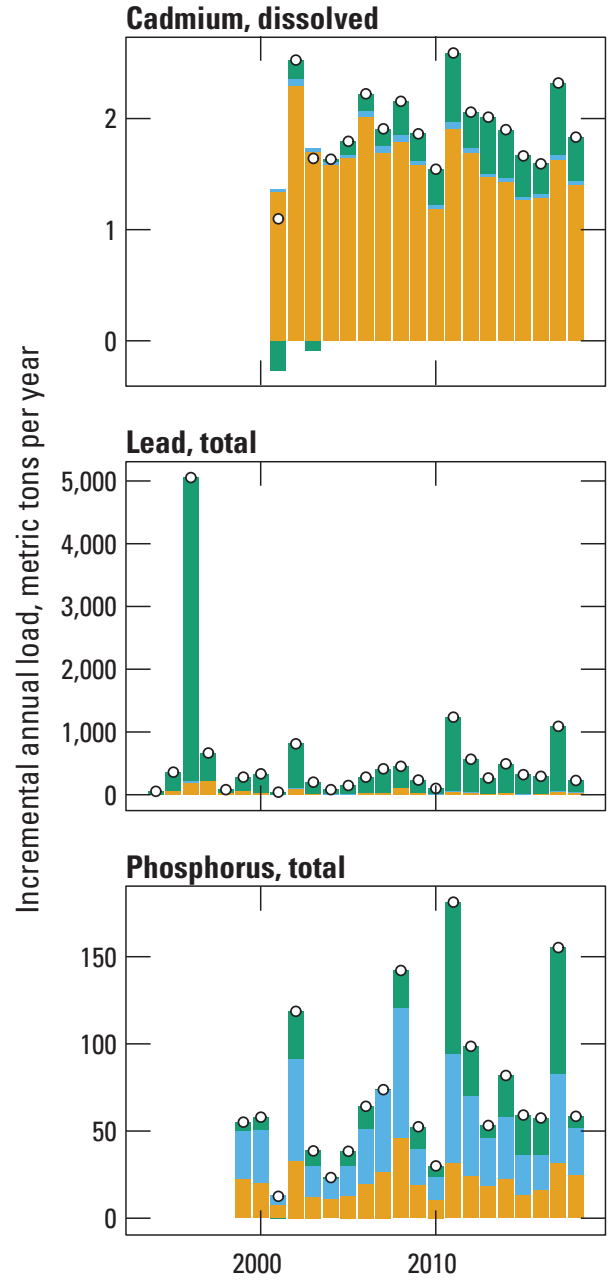

Main-stem Coeur d'Alene Rive
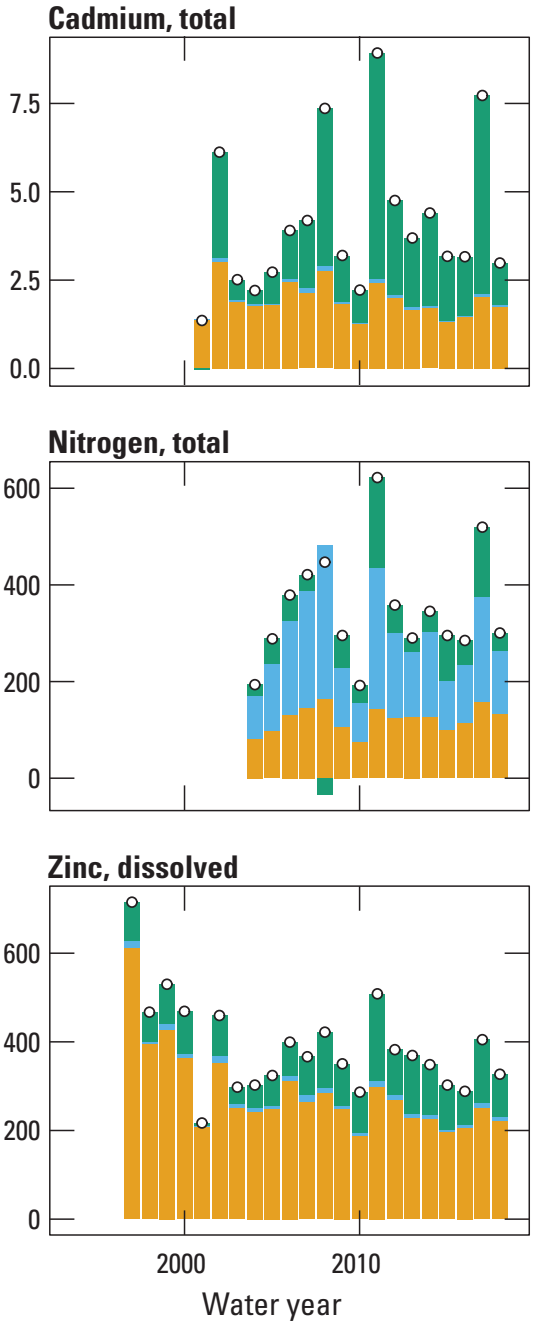

EXPLANATION

Reach
Lead, dissolved

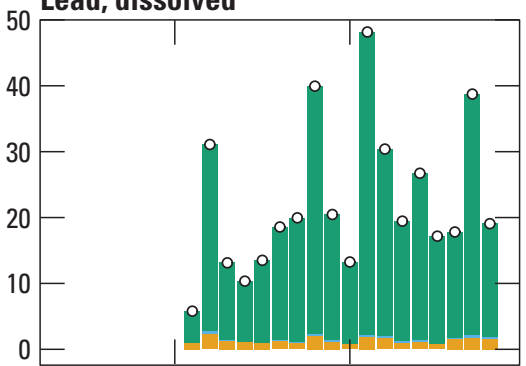

Orthophosphate
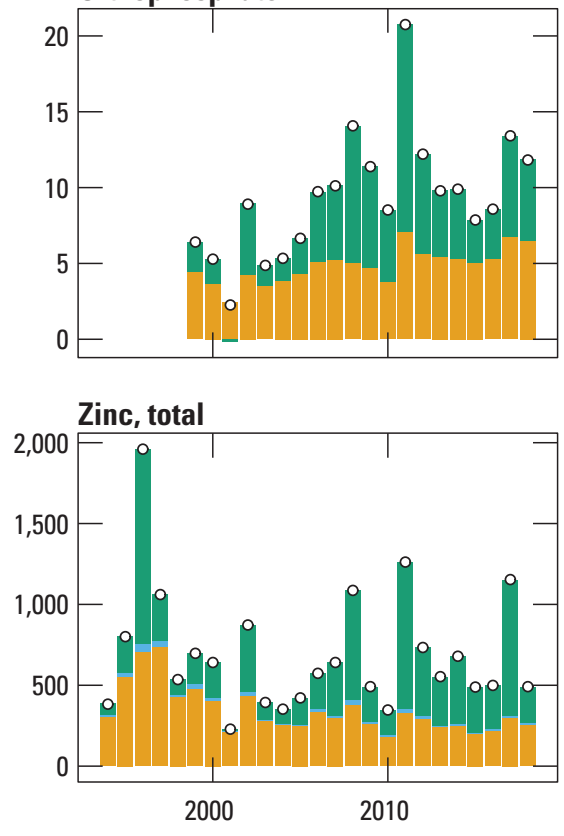

- Annual total load at Coeur d'Alene River near Harrison

Figure 18. Incremental annual total loads for the South Fork Coeur d'Alene River (SFCDR), the North Fork Coeur d'Alene River (NFCDR), and the main-stem Coeur d'Alene River (main-stem CDR), northern Idaho, water years 1994-2018. Load estimates were not available for all sites and constituents for every year. Annual total loads at the downstream-most site (CDR near Harrison) are shown with dots. SFCDR represents total loads in the SFCDR near Pinehurst. NFCDR represents total loads in the NFCDR at Enaville. Main-stem CDR loads represent total loads at CDR near Harrison minus loads from the SFCDR and NFCDR.

variability in streamflow. The total lead and dissolved lead loads flowing out of Coeur d'Alene Lake via the Spokane River were low relative to the amount flowing in, although more dissolved lead flowed out during high streamflow years (fig. 19).

Although the two rivers contributed roughly equal amounts of streamflow to the lake, more than half of the total nitrogen and orthophosphate load derived from the St. Joe River. The Spokane River exported total nitrogen equivalent to most of the total nitrogen load entering the lake except during high streamflow years, when it exported substantially less. Orthophosphate was not detected frequently enough to construct a model for the Spokane River below lake outlet, so for this analysis all orthophosphate that enters the lake stays in it, although it is likely that some net export of orthophosphate occurs. For total phosphorus, on average, about half of the load derived each from the CDR and St. Joe River. However, the CDR tended to contribute more than half during high streamflow years (for example, WYs 2008, 2011, and 2017), and the St. Joe River tended to contribute more than half during low or average streamflow years. Generally, the Spokane River exported total phosphorus equivalent to about 25 percent of the total phosphorus load entering the lake; this ratio was relatively insensitive to interannual variability in streamflow. 


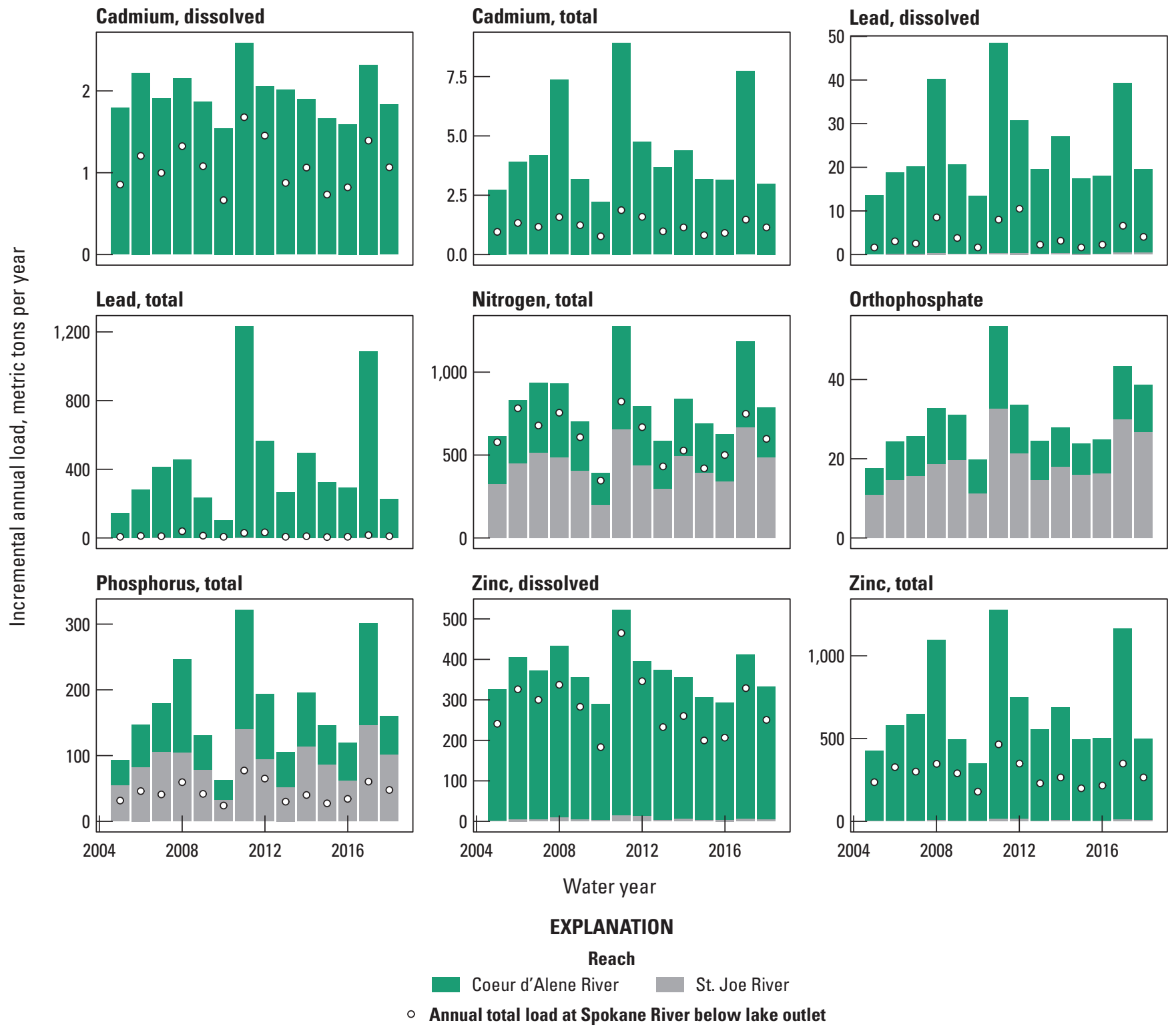

Figure 19. Annual total loads into and out of Coeur d'Alene Lake, northern Idaho, water years 2005-18. Annual total loads from the Coeur d'Alene River (CDR) represent annual total loads at CDR near Harrison. Annual total loads from the St. Joe River represent annual total loads at the St. Joe River at Ramsdell. Annual total loads out of Coeur d'Alene Lake represent annual total loads in the Spokane River below lake outlet and are shown with dots.

\section{Discussion}

The analyses presented in this report are intended to explore the current state of water quality in the study area and trends therein over the previous 30 years, specifically focusing on concentrations and loads of select metals and nutrients and the effects of remedial actions. Despite the focus on select constituents, water-quality trends in the study area are an expansive topic, and the results presented here rely on a large amount of data and supporting statistical analyses. As such, to better focus the discussion, this section is framed around a series of key questions regarding important constituents, patterns, and trends in the study area. This is not an exhaustive examination of the underlaying data and trends, but it does aim to address some major themes based on previous research and current topics in the study area. Furthermore, the study presented here is fundamentally a trends analysis; it illuminates patterns in water quality over 30 years but cannot directly identify the mechanisms responsible for those trends. Instead, this section relies on the trend analysis in conjunction with the body of existing technical literature describing constituent sources and mechanisms of transport to draw conclusions about change in the study area. 


\section{Metals}

First, have concentrations and loads of metals decreased since WY 1990? If so, what is the level of statistical confidence in these trends? And, finally, sharp decreases in metals concentrations were observed from the 1990s through the early 2000 s, but these decreases appeared to taper off in the 2010 s (Clark and Mebane, 2014)-have improvements continued in WYs 2009-18?

Total and dissolved zinc and cadmium and total lead concentrations and loads have decreased with high statistical likelihood ("likely down" or "somewhat likely down" trends) at most mining-affected sites across the study area over the period of record (the last 13-29 years; figs. 9, 12, and 14). One notable exception was the total lead load in the CDR near Harrison, which had a "somewhat likely up" trend over the period of record although dissolved zinc and cadmium at this site were "likely down." Furthermore, decreases in total and dissolved zinc and cadmium and total lead loads and concentrations persist with high statistical likelihood ("likely down" or "somewhat likely down" trends) at most sites over the most recent decade analyzed, WYs 2009-18, although the absolute magnitude of the decreases is smaller relative to the period of record. However, total lead load decreases at three sites, SFCDR at Elizabeth Park, SFCDR at Kellogg, and CDR near Harrison were "about as likely as not" during WYs 2009-18. The decreasing trends for most sites in WYs 2009-18 are most readily apparent in the flow-normalized concentrations and loads, where the variability driven by differences in annual streamflow is dampened (figs. 8, 11, and 13). By standardizing the trend periods (WYs 1999-2009 and WYs 2009-18) and looking just at the slope of the load trends, it is clear that although the absolute magnitude of the load decreases in WYs 2009-18 are smaller, the rate of the decreases is generally similar between the two periods (fig. 10). Thus, based on the analyses presented in this report, the concentrations and loads of key constituents in the study area have decreased with high statistical likelihood over the past 13-29 years (period of record), and have continued to decrease with high statistical likelihood at most sites during WYs 2009-18.

Next, how have remedial actions influenced these changes in concentrations and loads?

Although this trend analysis cannot specifically ascribe causality for trends, it can rely on existing documentation of metal sources, fate, and transport mechanisms to understand if observed trends are congruent with the likely impacts of remedial activities. Previous works have developed detailed conceptual models describing source, fate, and transport of metals in the Bunker Hill Superfund Site (URS Grenier, Inc., and CH2M HILL, 2001; CH2MHILL, 2006 and 2010a). In the SFCDR and tributaries, zinc, cadmium, and lead in primary sources such as adit and seep drainage, tailings and waste rock occur in approximately 1,088 source areas throughout the Bunker Hill Superfund Site. From these primary sources, zinc, cadmium, and lead are readily mobilized and transported in particulate and dissolved forms in surface water and in dissolved form in groundwater (URS Grenier, Inc., and CH2M HILL, 2001). Moreover, surface water and groundwater readily exchange in multiple areas of the Bunker Hill Superfund Site; for example, areas with bedrock constrictions force groundwater into rivers, and areas with bedrock expansions and a bigger alluvial aquifer promote surface water infiltration into groundwater. Such exchanges occur throughout the SFCDR watershed and have been specifically studied in Canyon Creek, the SFCDR near Osburn, and the SFCDR near Smelterville (Barton, 2002; CH2MHILL, 2009a-b; Zinsser, 2019). Secondary sources of metals therefore include soils, sediment, floodplain deposits, groundwater, and surface water that occur throughout the CDR watershed.

Numerous and varied actions by the EPA have been implemented across the Bunker Hill Superfund Site since the early 1990s. For example, remedial actions in the SFCDR watershed have included (but are not limited to) the removal of contaminated materials from streams and floodplains, consolidation of source materials, closure of waste repositories, demolition of mine and mill structures, remediation of specific mine sites, capping of the Central Impoundment Area, upgrades to the Central Treatment Plant, hillside erosion control, revegetation and riparian planting, and remediating the railroad right of way and subsequently opening the Trail of the Coeur d'Alenes (U.S. Environmental Protection Agency, 2012a). Additional cleanup activities have been implemented by other entities (including by the Bureau of Land Management in Pine Creek and by various site owners in Canyon Creek) and focused on removing contaminated materials from streams and proximal land surfaces (U.S. Environmental Protection Agency, 2012a).

The large and statistically likely decreases in total and dissolved cadmium, zinc, and lead concentrations and loads at sites throughout the SFCDR over the period of record are consistent with the anticipated effects of the many remedial actions that have occurred in the watershed during this time. For example, erosion of particulate lead, cadmium, and zinc during high streamflow from readily accessible mining wastes contributed to high loads during runoff events. Removal of these sources from streams and floodplains were among the earliest remedial activities throughout the Bunker Hill Superfund Site in the 1990s and early 2000s (U.S. Environmental Protection Agency, 2012a); this aligns with the period of steepest declines in particulate metal loads in SFCDR and tributary sites. Similarly, dissolved metal concentrations in surface water would be expected to decline steeply as these source materials were removed, and then continue to decline less steeply as groundwater concentrations gradually decrease over time in response to fewer source inputs. Again, this aligns with the concentration trends observed for dissolved metals in SFCDR and tributary sites. Ultimately, the strong and pervasive downward trends in total and dissolved metals in the SFCDR and tributary sites suggest that the remedial actions to remove primary materials from streams and floodplains and contain these materials in designed, intentional repositories have decreased cadmium and zinc loads and concentrations. 
In contrast to the high gradient SFCDR system, the main-stem CDR system is highly complex, comprising approximately 30 low-gradient, meandering river miles in fine grained substrate that are hydraulically connected to 12 shallow lateral lakes, thousands of acres of wetlands, and extensive floodplains (CH2MHILL, 2010a). Because of the nature and complexity of the river system in the main-stem CDR, the conceptual models for constituent transport in this area differ from those higher in the Bunker Hill Superfund Site. Most importantly, the major source of metals is contaminated sediments. The Cataldo Flats area, located at the confluence of the NFCDR and SFCDR, was the site of the largest tailings impoundment in the valley, and lead-rich sediment remains widely dispersed through the main-stem CDR system (U.S. Environmental Protection Agency, 2012a). These particulate metals are primarily mobilized by erosion from riverbanks and the channel bottom during high flow events; floodplain sediments are thought to be a relatively unimportant source of lead (CH2MHILL, 2010a). Contaminated sediments are also a source of dissolved metals within the main-stem CDR system. Oxic, suboxic, and anoxic zones can develop seasonally in the deeper riverbend, riverbank, marsh, wetland and lateral lakes zones. Under anoxic conditions, iron oxyhydroxide dissolves and can release adsorbed lead, zinc, and cadmium back into the water column. Organic matter can also adsorb and release zinc and cadmium, and lead complexed on organic material can be highly mobile (URS Grenier, Inc., and CH2M HILL, 2001; CH2MHILL, 2010c). Due to the complexity of contamination in the main-stem CDR, including the potential for recontamination from upstream sources, remedial activities in this area over the past 20 years have been focused on gaining an in-depth understanding of processes in this area and have included only limited source removals associated with popular recreation areas and construction of the Trail of the Coeur d'Alenes (U.S. Environmental Protection Agency, 2012a).

Given the nature of contaminant transport and relative lack of removal activities in the main-stem CDR, it is unsurprising but important that trends at CDR near Harrison vary somewhat from trends observed higher up in the watershed. Because the SFCDR is the source of the majority of the dissolved zinc and cadmium loads in CDR near Harrison (fig. 18), this site also experienced strong downward trends for these constituents, driven by upstream remedial actions. In contrast, the CDR main stem itself is the source of the majority of the total and dissolved lead at CDR near Harrison. Because contaminated sediments in the main-stem CDR have yet to be systematically addressed by widespread remedial activities in this area, it is logical that total and dissolved lead loads did not trend down during the period of record. So again, the trends observed in metals in the main-stem CDR are congruent with known sources of metals and mechanisms of transport in this area and are consistent with the history of remedial actions.

Finally, it is beyond the scope of this report to address how metals may transform in or transit through Coeur d'Alene Lake and whether these processes may be changing over time.
However, it is important to note that total and dissolved metal concentrations and loads in the Spokane River below lake outlet show large and statistically likely decreases over the period of record. Because these trends are similar in nature and timing to trends through the CDR watershed, this synchrony suggests that the water-quality improvements in the CDR, driven by extensive remedial activities, are also improving water quality in the Spokane River downstream of Coeur d'Alene Lake.

Can changes be attributed to specific remedial actions? How do the observed changes in AWQC ratios, concentrations, and loads compare to specific cleanup goals?

Despite the probable link between the metal trends and remedial actions in general, the method of trends analysis used here cannot detect step changes that may be associated with specific remedial actions. This is partly because so many actions have occurred simultaneously across the Bunker Hill Superfund Site, so the effects of each have compounded to yield large decreases in metals loads and concentrations at each monitoring site. This effect is especially apparent in the downstream-most sites (for example, SFCDR near Pinehurst), which experienced the largest load and concentration percent changes due to the additive improvements of each upstream site. Moreover, although the data collection efforts in the study area spanned many years, the sample frequency per year was relatively low (generally 4-6); this low frequency, combined with interannual streamflow variability, makes step changes associated with individual remedial actions harder to detect in the data. Most importantly though, WRTDS is fundamentally a statistical smoothing method that will inherently have a tendency to make step trends appears smoother than they are. In sum, it is possible that a different analysis approach could resolve discrete water-quality changes from specific actions, but the analyses presented here are not well-suited to detect such changes.

Likewise, step changes are not discernible in the AWQC ratios presented for the 20 WYs 2009-18 water-quality monitoring sites (figs. 3-5). Beyond the issues presented above, AWQC ratios can also vary widely at a given site as the underlying constituent concentrations and sample hardness vary with streamflow. For example, lead transport tends to be highest during spring runoff or flood streamflows when hardness values are also at their lowest, resulting in higher AWQC ratios relative to baseflow conditions. The AWQC ratios for a single site therefore can vary widely across the water year, which could also obscure step changes. However, for some sites with longer continuous data records such as SFCDR at Elizabeth Park and SFCDR near Pinehurst, decreases in dissolved zinc and dissolved cadmium AWQC ratios are only apparent after WY 1998 (figs. 3-4). This may indicate it took multiple remedial actions, and multiple seasons, for improvements in the AWQC ratios to become pronounced enough to be discernible from the variability induced by seasonal and annual streamflows. 
Although there are strong, downward trends in most metals at most sites over the period of record, direct comparisons of these decreases to cleanup goals are limited because specific, quantified cleanup goals are rare in the various Records of Decision. The 2002 Record of Decision for the Bunker Hill Superfund Site included several specific, comparable interim benchmarks for ecological receptors (U.S. Environmental Protection Agency, 2002). One benchmark for Canyon Creek aimed to reduce dissolved metal loading by 50 percent. Over the period of record at this site (WYs 1999-2018), dissolved cadmium loads decreased 50 percent, dissolved lead loads decreased 61 percent, and dissolved zinc loads decreased 40 percent (Zinsser, 2020). A benchmark for the main-stem Ninemile Creek was to reduce acute AWQCs ratios to less than 20; median chronic AWQC ratios (which are more stringent than acute for cadmium and lead) for WYs 2014-18 were 19, 1.3, and 16 for dissolved cadmium, dissolved lead, and dissolved zinc (respectively; table 7). Although limited, these comparisons provide another means to indicate the magnitude of improvement in zinc and cadmium concentrations and loads in the study area over the last several decades.

Next, are spatial patterns in metal loading changing (or not) across study area? Is the SFCDR still the main source of dissolved zinc and cadmium? Is the main-stem CDR still the main source of total and dissolved lead?

The majority of the dissolved zinc and cadmium loads in the CDR near Harrison still derive from the SFCDR (generally greater than 75 percent; fig. 18). However, as dissolved zinc and cadmium loads from the SFCDR have decreased over the period of record, this has impacted the relative contributions of different sources areas in the system. For example, although dissolved zinc and cadmium loads from the main-stem CDR have not changed in magnitude, their relative contribution to the total load at CDR near Harrison has become bigger. The main-stem CDR has continued to contribute the majority of the total and dissolved lead loads (generally greater than 75 percent; fig. 18).

A few other notable spatial patterns in constituent transport are evident in the incremental annual total load analyses. First, for most sites in the upper CDR watershed (above SFCDR near Pinehurst), strong decreasing trends in total lead loads and concentrations correspond with remedial actions. One notable exception, however, is the SFCDR at Elizabeth Park and the next downstream site, SFCDR at Kellogg (fig. 14). The lack of strong trends, down or otherwise, at these sites suggests there is still an active total lead source upstream. The upstream reach includes Osburn Flats, which is a recognized source of tailings that continues to be addressed through remedial activities. In the early 1900s, a plank-and-pile dam was built in this relatively broad, flat part of the valley to impound tailings; the dam was subsequently breached multiple times during high streamflows, resulting in substantial downstream transport of tailings. Nonetheless, large quantities of tailings remain in the valley (U.S. Environmental Protection
Agency, 2012a). The total lead concentration and load trend data for the sites immediately downstream of this area suggest that Osburn Flats may be a continuing source of total lead in the SFCDR.

Trends in concentrations and loads and incremental load patterns in the main-stem CDR show some important differences compared to those in the SFCDR. Sampling access to this area is limited to a few bridges or boat-based sampling; consequently, long-term monitoring data are spatially sparse, which limits the resolution of this analysis. Nonetheless, some patterns are apparent. In the main-stem CDR, concentrations of total lead have decreased over the period of record, but loads either have "somewhat likely down" trends (WYs 2009-18) or are increasing (period of record; fig. 14). The improvements in main-stem CDR total lead concentrations may be due to downstream propagated improvements from the SFCDR. In contrast, loads have not improved because high streamflow events that mobilize substantial quantities of total lead-rich sediment from within the main-stem CDR itself are the primary drivers of the total lead load, and these sources have not yet been remediated. It is, however, unclear why total lead loads increased in WYs 1999-2009 but decreased in WYs 2009-18 (fig. 10). Generally, riverbed sediment characterization in the main-stem CDR suggests that as the river erodes deeper into the bed over time, sediment with higher lead concentrations will be accessible (CH2MHILL, 2010d). However, although specific reaches are known to have eroded doing specific high streamflow events, it is not clearly understood whether the main-stem CDR overall has been eroding over the past 20 years (CH2MHILL, 2010b). Thus, it is possible that higher lead loads during WYs 1999-09 were associated with increased erosion in the main-stem CDR but more data are needed to support this hypothesis.

\section{Nutrients}

As described in this report's Introduction, nutrients are not constituents of concern under any of the Records of Decision but are a current concern in the study area due to their potential impact on the trophic status of Coeur d'Alene Lake. In contrast to the metals, datasets for total phosphorus, total nitrogen, and orthophosphate were generally sparser and had more variable trends. These constituents also have less prior research to guide questions on trends and patterns of transport in the study area. Nonetheless, some broad questions were explored here, but additional data and analysis would help to improve understanding of the changes and mechanisms driving the trends.

Are there trends in total phosphorus concentrations and loads in the study area? Where and over what time scales? What is the level of statistical confidence in these results? What can and cannot be inferred about sources, processes and spatial patterns in loading from these results? 
Generally, the period of record total phosphorus results were striking for having several sites with "likely up" or "somewhat likely up" trends (SFCDR at Smelterville, SFCDR near Pinehurst and CDR near Harrison), whereas the WYs 2009-18 results were striking for the opposite reason-these same sites had "likely down," "somewhat likely down," or "as likely as not" trends (fig. 16). The slope analysis helps resolve these trends, showing that total phosphorus load changes were positive at SFCDR at Smelterville, SFCDR near Pinehurst, NFCDR at Enaville, and CDR near Harrison from WY 2002 to 2009 and negative or close to 0 at each of these sites for WYs 2009-18 (fig. 10). The general (although not perfect) agreement between concentration and load trends and the analysis of spatial patterns in loading suggests that the major sources of total phosphorus are most important during high streamflows. The lack of consistent trends across study area, particularly in the upper SFCDR, NFCDR, and St. Joe River, indicate that regional mechanisms such as atmospheric deposition or changes in forestry practices are unlikely to be driving phosphorus trends. Similarly, it is improbable that geologic sources of phosphorus would affect spatially heterogeneous, decadalscale trends, and the Belt Supergroup rocks that underlie much of study area have low phosphorus content (Harrison and Grimes, 1970; Lewis and Frost, 2005). Furthermore, important albeit subtle differences in the magnitude and direction of the trends in the SFCDR sites and CDR near Harrison suggest that phosphorus trends at these sites may be responding to fundamentally different drivers.

With respect to the SFCDR sites, the load increase in SFCDR near Pinehurst in the 2000s was similar to the load increase in SFCDR at Smelterville, indicating that change in the latter may have driven the trend in SFCDR near Pinehurst over this period. However, the biggest change in SFCDR near Pinehurst occurred from WY 1990 to 1999, when there was no data from SFCDR at Smelterville, and the decrease in SFCDR near Pinehurst in WYs 2009-18 was much stronger and larger than the decrease in SFCDR at Smelterville over the same time period (Zinsser, 2020). Thus, while the total phosphorus load from SFCDR at Smelterville likely influences trends in SFCDR near Pinehurst to some extent, it is not the only control.

There are a variety of known sources of total phosphorus to the SFCDR between Kellogg and Pinehurst. The reach between Kellogg and Smelterville, adjacent to the Central Impoundment Area, contributes a substantial total phosphorus load via groundwater contributions to the SFCDR. Groundwater modeling for WYs 2009-14 shows that this load is relatively constant year-to-year, despite interannual variability in streamflow, and is also relatively consistent seasonally, at least for the modelled period (CH2M, 2018). The total phosphorus in the groundwater in this reach derives from gypsum wastes in the Central Impoundment Area that were a byproduct from the phosphoric acid and fertilizer plant in Government Gulch. Substantial remediation activities have occurred associated with the plant and these wastes since the 1990s, including removal, consolidation, and capping of wastes that were formerly in the stream channels of several small tributaries to the SFCDR (U.S. Environmental Protection Agency, 2012a). It is, however, unexpected that removal and consolidation activities in the 1990s would have caused loading increases to the SFCDR during the early 2000s before leveling off in the 2010s, so it seems unlikely that these wastes would be responsible for observed increases.

There are two permitted wastewater treatment systemsPage wastewater treatment plant and the much smaller Smelterville facility-in the reach between Smelterville and Pinehurst. Limited data suggest that loads from these facilities have remained similar since the early 1990s (Idaho Department of Environmental Quality and Coeur d'Alene Tribe, 2019). The reach between Kellogg and Pinehurst is also relatively urbanized compared to the rest of study area, containing several small towns, the I-90 interstate, various impervious surfaces, and stormwater systems in addition to the mining-related features all within the narrow valley floor. The annual load results for this reach suggest that runoff-related total phosphorus loads are important during high water years (fig. 17). Thus, it is likely that stormwater and other runoffs are important (albeit difficult to quantify) contributors of total phosphorus to this reach and may have contributed to trends over the period of record. For example, remedial actions have included substantial paving efforts to isolate contaminated road base materials and other efforts to reduce surface erosion from mining-related features. While most of the SFCDR is forested, the mining impacted and redeveloped areas between Kellogg and Pinehurst are heavily concentrated along the SFCDR. It is possible that these efforts initially increased stormwater runoff to the streams, particularly as revegetation efforts began, and have become less important as surface erosion stabilization efforts across the area have taken effect.

Although both SFCDR near Pinehurst and CDR near Harrison have "likely up" trends in total phosphorus over the period of record (fig. 16), they functionally represent the aggregate loads over very different stretches of river and are likely responding to different drivers. As described in the Results, the shorter period of record results at CDR near Harrison are not directly comparable to the longer period of record results for SFCDR near Pinehurst because of the difference in record length. There is no discernible trend in NFCDR at Enaville over the period of record, and the increase in CDR near Harrison (6.7 metric tons) is superficially comparable in scale to the increase in SFCDR near Pinehurst (8 metric tons). However, the time span represented by each period of record is drastically different, with the SFCDR near Pinehurst record representing WYs 1990-2018 and the CDR near Harrison record representing WYs 1998-2018 (Zinsser, 2020). Total phosphorus data were too sparse at CDR near Harrison in the 1990s to extend the model back to WY 1991; there was only one sample analyzed for total phosphorus between WY 1993 and 1997. However, over 50 samples were collected in calendar years 1991-92 in CDR near Harrison, and multiple authors have used these samples to estimate loads previously. Woods and Beckwith (1997) estimated annual loads of 22 and 
10 metric tons in calendar years 1991 and 1992, respectively, using FLUX; Wood and Beckwith (2008) later estimated 33.6 and 10.9 metric tons in calendar years 1991 and 1992 , respectively, using LOADEST. Although the prior estimates vary from each other, both estimates are drastically lower than the WRTDS_K (55 metric tons) and WRTDS flow-normalized annual loads (61.7 metric tons) calculated here for WY 1999 (Zinsser, 2020). Water years are different than calendar years, but the rough comparison suggests that, during the 1990s, the change in load at SFCDR near Pinehurst (approximately 10 metric tons) can account for only a fraction of the change observed in the CDR near Harrison (approximately 20-33 metric tons). This load disparity suggests that different sources of total phosphorus and/or mechanisms of transport are largely responsible for trends in the CDR near Harrison.

Despite these data limitations, the load estimates from Woods and Beckwith (1997) combined with the WRTDS results presented here suggest that the 1990s were evidently a period of much bigger phosphorus load increases for CDR near Harrison, with more modest increases in the 2000s, and declines in recent times (Zinsser, 2020). These broad trends are similar to those observed for SFCDR near Pinehurst. Furthermore, the increasing trends in CDR near Harrison from approximately 1991-2010 are consistent with recent analyses by Idaho Department of Environmental Quality and Coeur d'Alene Tribe (2019), but because this report incorporated additional years (WYs 2014-18), the decreasing trend in WYs 2009-2018 is newly identified here. As described in the Metals section of the Discussion, the main-stem CDR is a long, low-gradient river connected to a series of shallow, productive lateral lakes and wetlands, with water and sediment conveyed between these features and the main stem via lateral connecting channels (CH2MHILL, 2010c). Phosphorus is not conservative, and it is likely that major transformations occur throughout this reach; for example, the main-stem CDR adds substantial orthophosphate loads (fig. 18). It is likewise notable that the biggest total phosphorus and orthophosphate loads in the main-stem CDR occurred during high streamflow years, suggesting that floodwaters accessing lateral lakes, floodplains, and wetlands may pick up substantial phosphorus loads during these years. Alternately, high streamflow years are also known to erode and transport substantial quantities of particulate lead from the bed of the CDR (Box and others, 2005; CH2M, 2016), and it is possible that some particulate phosphorus load is also stored in and then entrained from the bed of the river during these events. Particulate phosphorus storage on riverbeds and in floodplains can be important to annual phosphorus loads, and phosphorus retained in connected ponds can be an important source of orthophosphate (Withers and Jarvie, 2008). However, even if these sources are responsible for adding phosphorus to the main-stem CDR during high streamflows, it is unclear why or how the rate of these processes would have increased strongly in the 1990s, less strongly in the 2000s, and then decreased in the 2010s.
One possibility is that flooding in 1996, which represents the second-highest streamflow recorded at CDR near Cataldo since 1920 (Box and others, 2005), perturbed the main-stem CDR system to make phosphorus more readily available for transport. Although there was no systematic study of geomorphic change resulting from the 1996 flood event, the event encompassed prolonged, extensive overbank flooding that eroded streambank deposits and suspended floodplain soils (Box and others, 2005). The prolonged flooding and eventual retreat of floodwaters could have either made a substantial amount of total phosphorus directly accessible (that is, by deposition of phosphorus-rich sediment in the main channel) or created better continual access to the lateral lakes and marshes (that is, by scouring out connective channels between the main stem and these features). Changes resulting from these mechanisms could potentially account for the large (albeit anecdotal) increase in total phosphorus load between calendar years 1991 and 1992 and WY 1999 and then account for reduced increases in the early 2000s as the main-stem CDR slowly returned to its previous condition (that is, erosion of the high-phosphorus sediments or more limited access to wetlands and marshes). Metal analyses of flood deposit sediments associated with a series of floods in the 1990s found that the 1996 flood was sufficiently large to erode both floodplain soils and streambed sediments, whereas smaller floods (more readily equivalent to annual spring runoff streamflows) tended to primarily mobilize sediment from the streambed (Box and others, 2005).

Thus, based on subtle but key differences in phosphorus concentrations and loads and innately different environments, phosphorus trends at sites in the SFCDR and at the CDR near Harrison are likely responding to different processes of phosphorus production and mechanisms of transport. However, interpretation of the mechanisms underlying these trends remains limited due to the spatial and temporal sparseness of the underlying data.

\section{Is there a link between metals and phosphorus in the} study area?

Thus far in this report, since the motivation for analyzing metals and nutrients differed, the two types of constituents have been considered separately. But as Idaho Department of Environmental Quality and Coeur d'Alene Tribe (2019) have pointed out, there is some spatial concurrence between important sources of metals and nutrients in the SFCDR and main-stem CDR. While this is true, the link between metals and nutrients seems to be indirect at best. First, as described here, the trends for metal concentrations and loads differ substantially from those for total phosphorus and orthophosphate, which indicates that governing processes for each differ. Second, while there is one identified source of phosphorus associated with mining activities (the phosphoric acid wastes in the Central Impoundment Area), loading from this source has been explicitly estimated (CH2M, 2018; Zinsser, 2019) and represents only a small fraction of the phosphorus present in the CDR system. On average, the modeled phosphorus 
loading from Central Impoundment Area groundwater to the SFCDR was about 6.5 metric tons per year in WYs 2009-14 (CH2M, 2018), whereas the average annual total phosphorus load in CDR at Harrison over the same time period was about 80 metric tons (Zinsser, 2020). Thus, most of the phosphorus in the system clearly derives from other sources.

However, there are a variety of ways in which the various and extensive remedial actions across the Bunker Hill Superfund Site could indirectly affect phosphorus production and loading. For example, widespread paving and redevelopment of lands proximal to the SFCDR could have increased impervious surfaces and increased surface runoff, whereas remedial actions to revegetate land surfaces and riparian areas, mitigate surface erosion, and reduce bank erosion could have reduced surface runoff and instream sediment loading. Reduced sediment and metal concentrations and loads resulting from remedial actions could have increased water clarity and allowed for greater primary productivity, particularly in the main-stem CDR (Idaho Department of Environmental Quality and Coeur d'Alene Tribe, 2019). There could also be some hereto unrecognized connection between high lead content and high phosphorus content in sediments stored in the main-stem CDR. Thus, while the data presented here suggest that the processes governing metal and phosphorus transport and the trends therein are fundamentally different, remedial actions could be indirectly affecting nutrient trends in a variety of ways.

\section{Topics for Additional Study}

While the analyses presented here have characterized a series of important trends in concentrations and loads in the study area over the last 30 years and attempted to address some key themes, there remain substantial gaps in our understanding of the system. For example, as SFCDR loads decline, the main-stem CDR is an increasingly important source of particulate and dissolved cadmium and zinc, contributes one quarter of the total phosphorus load, and remains the main source of total and dissolved lead. Yet sampling in the mainstem CDR is limited to the few bridges in the 30-mile stretch. Isokinetic sampling from boats is possible but difficult during the high streamflow conditions that are critical to understanding this part of the system thus making bridge sampling highly preferable. Therefore, continuing to build on existing data records, including adding more years of data collection for the CDR at Rose Lake and continuing sampling at CDR near Cataldo and CDR near Harrison for the full suite of constituents, will help in establishing and monitoring long-term trends, particularly as remedial efforts shift towards this part of the CDR watershed.

This study focused on annual mean concentrations, annual total loads, and trends therein, but there are also WRTDS extensions available to explore trends in seasonal and mean monthly concentrations and loads (Choquette and others, 2019), which also could potentially help explain spatial and temporal loading dynamics for a variety of constituents. For example, considering data at a higher temporal resolution would likely yield insights into transport of particulate zinc and cadmium, which tend to be a minor fraction of these total metals but relatively more important during high streamflow events. Likewise, analysis of dissolved metals loading in the main-stem CDR during low streamflow might elucidate how loading dynamics associated with these constituents are changing over time. A thorough accounting of historical and current point sources and likely nonpoint contributions of phosphorus in the SFCDR between Kellogg and Pinehurst, paired with higher temporal resolution in loading data (that is, seasonal or monthly loads), would help in understanding the complex nutrient trends in this reach. Similarly, mechanisms of total phosphorus production and transport in the main-stem CDR are speculative and based on literature review; additional monitoring or higher resolution temporal analysis could be helpful for understanding total phosphorus transport in this part of the CDR watershed.

The limited streamflow analyses conducted here suggest that annual and seasonal streamflow maximums, medians, and minimums have not significantly changed in the past 30 years. However, climate change is impacting streamflow in the region. For example, Clark (2010) examined multiple unregulated streams in Idaho and surrounding states and found significant shifts towards earlier spring runoff in the St. Joe River from 1967 to 2007. Looking at broader atmospheric climate signals across the Northwest, Abatzoglou and others (2014) found increased temperatures and increased spring and summer precipitation in northern Idaho. The most important loading events in the study area are the rare rain-on-snow events and the annual snowmelt runoff; shifts in precipitation and temperature patterns will affect streamflow patterns and likely affect these large loading events, but it is presently unclear how. A more extensive analysis of potential changes to snowmelt runoff magnitude, duration, and timing, and an examination of the frequency of the rarer rain-on-snow events would help elucidate potential impacts to loading in the study area and have potential ramifications for approaches to remedial actions moving forward.

\section{Summary}

Long-term surface water-quality monitoring data from the Coeur d'Alene River (CDR) and St. Joe and Spokane Rivers (collectively, "the study area") were used to generate Weighted Regressions on Time, Discharge and Season (WRTDS) and WRTDS with Kalman filtering (WRTDS_K) models to estimate annual mean concentrations, annual total loads, flow-normalized annual mean concentrations, and flow-normalized annual total loads. Bootstrapped confidence intervals were constructed to determine the statistical likelihood of trends and the slope of trends in flow-normalized concentrations and loads over the period of record (which 
varied from 13 to 29 years), water years (WY) 1999-2009 and WYs 2009-2018. Constituents studied were total and dissolved cadmium, lead and zinc; total phosphorus and nitrogen; and total orthophosphate.

Throughout the study area at mining-affected sites, most metal loads and concentrations decreased with high statistical likelihoods over the period of record and WYs 2009-18. Specifically, total and dissolved zinc and cadmium concentrations and loads had "likely down" trends of about 25-75 percent over the period of record and "likely down" trends of about 10-30 percent during WYs 2009-18. Total and dissolved lead concentrations and loads had "likely down" trends of about 20-85 percent over the period of record and had "likely down" or "somewhat likely down" trends of about 10-50 percent during WYs 2009-18. One exception to this was total lead load in CDR near Harrison, which had "somewhat likely up" trends for total lead over the period of record. Close temporal synchrony between statistically "likely down" trends in metal concentrations and loads and the onset of extensive remedial actions throughout the Bunker Hill Superfund Site indicate that remedial actions are improving water quality at mining-affected sites in the study area. Ambient water-quality criteria ratios for dissolved cadmium, lead, and zinc have consistently declined across miningaffected sites in the study area over the period of record, although concentrations remain above chronic aquatic criteria in most locations. Thus, although the effects of individual remedial actions on water-quality improvements cannot be discerned with this analysis, strong decreasing trends in metals concentrations and loads demonstrate that remedial actions over the last 30 years have improved water quality at miningaffected sites in the study area.

Analyses of incremental annual total load estimates illustrated spatial patterns in load sources in the study area and indicated some key locations for focusing future remedial efforts. Substantial loading of total lead in the South Fork Coeur d'Alene River (SFCDR) above Elizabeth Park may be related to tailings still located in the Osburn Flats area and represents an opportunity for additional remedial actions. The SFCDR remained the source of the majority of dissolved zinc and cadmium loads into Coeur d'Alene Lake, and the mainstem CDR remained the source of the majority of total and dissolved lead loads into Coeur d'Alene Lake. The main-stem CDR was also an important source of particulate cadmium and zinc, particularly during high streamflow years. These results were unsurprisingly but nonetheless important because remedial actions have not yet directly addressed widely dispersed particulate contaminants in the main-stem CDR system. The presence of these particulate contaminants, in conjunction with geochemical processes, also serve as a continuing source of dissolved lead, zinc, and cadmium in the main-stem CDR.
Trends in total phosphorus were variable both temporally and spatially in the study area during the period studied, but several broader patterns emerged. Temporally, total phosphorus loads and concentrations increased most during the 1990s, increased less during the 2000s, and decreased or remained the same during the 2010s. Spatially, the lack of consistent trends in the North Fork CDR, upper SFCDR, and St. Joe River, and inconsistencies between trends in upstream (SFCDR at Smelterville and SFCDR near Pinehurst) and downstream (CDR near Harrison) sites, strongly suggested that local processes and mechanisms were most important for driving changes. Analyses of incremental annual total loads indicated that the biggest phosphorus loads in the SFCDR and main-stem CDR occurred during high streamflow years, which points to the importance of phosphorus sources active during runoff conditions. In the SFCDR between Kellogg and Pinehurst, stormwater or other unaccounted surface runoffs may be important load sources, and these loads may have been more important in the 1990s and less so in the 2000s as remedial actions to limit surface erosion and revegetate landscapes began and took effect. In the CDR near Harrison, it is possible that near-record flooding in 1996 increased access to productive floodplains and lateral lakes in the main-stem CDR system, making total phosphorus more readily available for transport during subsequent runoff flows. However, mechanistic interpretations of the total phosphorus trends were fundamentally limited by the spatial and temporal sparseness of the underlying data and the relative paucity of technical information regarding phosphorus dynamics in the study area.

In summary, robust statistical analyses of long-term surface water-quality monitoring data in the Spokane River watershed are strong evidence of reduced metal concentrations and loads from the combined effects of remedial actions over the previous 30 years and yielded insights into the major source areas for metals and nutrients.

\section{Acknowledgments}

The analyses presented in this report would not have been possible without the dedication of numerous U.S. Geological Survey staff over many years and seasons, braving the elements to collect water-quality samples and streamflow measurements in every condition. The author appreciates the constructive reviews of an earlier manuscript draft by Chris Mebane and Bob Hirsch (U.S. Geological Survey), and Kim Prestbo and Chris Eckley (U.S. Environmental Protection Agency) which helped improve the final report. 


\section{References Cited}

Abatzoglou, J.T., Rupp, D.E., and Mote, P.W., 2014, Seasonal climate variability and change in the Pacific Northwest of the United States: Journal of Climate, v. 27, no. 5, p. 2125-2142, https://doi.org/10.1175/JCLI-D-13-00218.1.

Barton, G.J., 2002, Dissolved cadmium, zinc, and lead loads from ground-water seepage into the South Fork Coeur d'Alene River system, northern Idaho, 1999: Reston, Virginia, 2001-4274, 134 p., at https://doi.org/10.3133/ wri014274.

Beckwith, M.A., 1996, Water-quality data collected during floods in the Coeur d'Alene River, northern Idaho, February 1996: U.S. Geological Survey Fact Sheet 219-96, 4 p., http://pubs.er.usgs.gov/publication/fs21996.

Beckwith, M.A., 1998, Concepts for monitoring water quality in the Spokane River Basin, northern Idaho and eastern Washington: U.S. Geological Survey Open-File Report 98-534, 31 p., http://pubs.er.usgs.gov/publication/ofr98534.

Beckwith, M.A., Woods, P.F., and Berenbrock, C., 1997, Trace-element concentrations and transport in the Coeur d'Alene river, Idaho, water years 1993-94: U.S. Geological Survey Open-File Report 97-398, 10 p, http://pubs.er.usgs.gov/publication/ofr97398.

Box, S.E., Bookstrom, A.A., and Ikramuddin, M., 2005, Stream-sediment geochemistry in mining-impacted streams - Sediment mobilized by floods in the Coeur d'Alene-Spokane River system, Idaho and Washington: U.S. Geological Survey Scientific Investigations Report 2005-5011, 57 p., http://pubs.er.usgs.gov/publication/ sir20055011.

CH2MHILL, 2006, Current status, conceptual site model, Operable Unit 2, Bunker Hill Mining and Metallurgical Complex Superfund Site: CH2MHILL, prepared for the U.S. Environmental Protection Agency, 14 p.

CH2MHILL., 2009a, Osburn Flats groundwater-surface water interaction study, Bunker Hill Mining and Metallurgical Complex Superfund Site: CH2MHILL, prepared for the U.S. Environmental Protection Agency, 144 p.

CH2MHILL, 2009b, OU2 2008 groundwater/surface water interaction monitoring data summary: CH2MHILL, 97 p.

CH2MHILL, 2010a, Enhanced conceptual site model for the Lower Basin Coeur d'Alene River-Executive summary: CH2MHILL, 90 p.
CH2MHILL, 2010b, Enhanced conceptual site model for the Lower Basin Coeur d'Alene River: Technical Memorandum E-Fluvial Geomorphology, 87 p.

CH2MHILL, 2010c, Enhanced conceptual site model for the Lower Basin Coeur d'Alene River: Technical Memorandum F-Geochemical Characteristics, 34 p.

CH2MHILL, 2010d, Enhanced conceptual site model for the Lower Basin Coeur d'Alene River: Technical Memorandum $\mathrm{G}-$ Contaminant Sources and Characteristics, 167 p.

CH2MHILL, 2016, Enhanced conceptual site model for the Lower Basin Coeur d'Alene River: Technical Memorandum Addendum D-3 - Processes of Sediment and Lead Transport, Erosion and Deposition, 202 p.

CH2MHILL, 2018, Draft final Operable Unit 2 groundwater collection system remedial Action Effectiveness Monitoring Plan, Bunker Hill Mining and Metallurgical Complex Superfund Site: CH2MHILL, prepared for U.S. Environmental Protection Agency, Region 10, 118 p.

Choquette, A.F., Hirsch, R.M., Murphy, J.C., Johnson, L.T., and Confesor, R.B., 2019, Tracking changes in nutrient delivery to western Lake Erie-Approaches to compensate for variability and trends in streamflow: Journal of Great Lakes Research, v. 45, no. 1, p. 21-39, https://dx.doi.org/ 10.1016/j.jglr.2018.11.012.

Clark, G.M., 2003, Occurrence and transport of cadmium, lead, and zinc in the Spokane River basin, Idaho and Washington, water years 1999-2001: U.S. Geological Survey Water Resources Investigations Report 2002-4183, 45 p., accessed September 13, 2019, at https://doi.org/10.3133/wri024183.

Clark, G.M., 2010, Changes in patterns of streamflow from unregulated watersheds in Idaho, Western Wyoming, and Northern Nevada: Journal of the American Water Resources Association, v. 46, no. 3, p. 486-497, https://doi.org/ 10.1111/j.1752-1688.2009.00416.x.

Clark, G.M., and Mebane, C.A., 2014, Sources, transport, and trends for selected trace metals and nutrients in the Coeur d'Alene and Spokane River Basins, Idaho, 1990-2013: U.S. Geological Survey Scientific Investigations Report 2014-5204, 74 p., http://pubs.er.usgs.gov/publication/ sir20145204.

De Cicco, L.A., Hirsch, R.M., and Murphy, J., 2019, EGRETci-Exploration and graphics for RivEr Trends Confidence Intervals: CRAN-R Project, https://cran.rproject.org/package=EGRETci. 
Donato, M.M., 2006, Annual trace-metal load estimates and flow-weighted concentrations of cadmium, lead, and zinc in the Spokane River basin, Idaho and Washington, 1999-2004: U.S. Geological Survey Scientific Investigations Report 2006-5188, 44 p., http://pubs.er.usgs.gov/ publication/sir20065188.

Edwards, T.K., and Glysson, G.D., 1988, Field methods for measurement of fluvial sediment: U.S. Geological Survey Open-File Report 86-531, http://pubs.er.usgs.gov/ publication/ofr86531.

Edwards, T.K., and Glysson, G.D., 1999, Field methods for measurement of fluvial sediment: U.S. Geological Survey Techniques of Water-Resources Investigations 03-C2, http://pubs.er.usgs.gov/publication/twri03C2.

Fishman, M.J., 1993, Methods of analysis by the U.S. Geological Survey National Water Quality LaboratoryDetermination of inorganic and organic constituents in water and fluvial sediments: U.S. Geological Survey OpenFile Report 93-125, http://pubs.er.usgs.gov/publication/ ofr93125.

Fryklund, V.C., and Weis, P.L., 1964, Ore deposits of the Coeur d'Alene District, Shoshone County, Idaho, with a section on the bleached rock in the Coeur d'Alene District: U.S. Geological Survey Professional Paper 445, accessed September 13, 2019, at https://doi.org/10.3133/pp445.

Garbarino, J.R., Kanagy, L.K., and Cree, M.E., 2006, Determination of elements in natural-water, biota, sediment, and soil samples using collision/reaction cell inductively coupled plasma-mass spectrometry: U.S. Geological Survey Techniques and Methods, book 5, sec. B, chap. 1. 88 p., http://pubs.er.usgs.gov/publication/tm5B1.

Gillerman, V.S., 2019, Idaho Mining and Exploration, 2019: American Exploration and Mining Association: accessed February 12, 2020, at https://www.idahogeology.org/pub/ MineDocs/Regional_Development/2019RDp.pdf.

Granato, G.E., 2009, Computer programs for obtaining and analyzing daily mean steamflow data from the U.S. Geological Survey National Water Information System Web Site: U.S. Geological Survey Open-File Report 2008-1362, http://pubs.er.usgs.gov/publication/ofr20081362.

Harrison, J.E., and Grimes, D.J., 1970, Mineralogy and geochemistry of some belt rocks, Montana and Idaho: Geological Survey Bulletin 1312O, http://pubs.er.usgs.gov/ publication/b1312O.
Helsel, D.R., 2006, Fabricating data-How substituting values for nondetects can ruin results, and what can be done about it: Chemosphere, v. 65, no. 11, p. 2434-2439, https://doi.org/10.1016/j.chemosphere.2006.04.051.

Helsel, D.R., and Hirsch, R.M., 2002, Statistical methods in water resources: Techniques of Water-Resources 04-A3, http://pubs.er.usgs.gov/publication/twri04A3.

Helsel, D.R., Hirsch, R.M., Ryberg, K.R., Archfield, S.A., and Gilroy, E.J., 2020, Statistical methods in water resources: U.S. Geological Survey Techniques, book 4, chapter A3, 458 p., http://pubs.er.usgs.gov/publication/tm4A3.

Hirsch, R.M., 1982, A comparison of four streamflow record extension techniques: Water Resources Research, v. 18, no. 4, p. 1081-1088, https://doi.org/10.1029/ WR018i004p01081.

Hirsch, R.M., 2014, Large biases in regression-based constituent flux estimates - Causes and diagnostic tools: Journal of the American Water Resources Association, v. 50, no. 6, p. 1401-1424, https://doi.org/10.1111/jawr.12195.

Hirsch, R.M., 2018, Daily streamflow trend analysis: U.S. Geological Survey Exploration and Graphics for RivEr Trends (EGRET), Daily Streamflow Trend Analysis, accessed January 3, 2020, at http://usgs-r.github.io/EGRET/ articles/streamflow_trend.html.

Hirsch, R.M., 2019, Making WRTDS_K flux estimates: U.S. Geological Survey Exploration and Graphics for RivEr Trends (EGRET), Making WRTDS_K flux estimates, accessed January 8, 2020, at http:/usgs-r.github.io/EGRET/ articles/Making\%20WRTDS_K\%20flux\%20estimates.html.

Hirsch, R.M., Archfield, S.A., and De Cicco, L.A., 2015, A bootstrap method for estimating uncertainty of water quality trends: Environmental Modelling \& Software, v. 73, p. 148-166, http://dx.doi.org/10.1016/j.envsoft.2015.07.017.

Hirsch, R.M., and De Cicco, L.A., 2015, User guide to exploration and graphics for RivEr Trends (EGRET) and dataRetrieval — R packages for hydrologic data: U.S. Geological Survey Techniques and Methods 4-A10, 104 p., http://pubs.er.usgs.gov/publication/tm4A10.

Hirsch, R.M., and DeCicco, L.A., 2018, Guide to EGRET 3.0 enhancements: U.S. Geological Survey Exploration and Graphics for RivEr Trends (EGRET), Guide to EGRET 3.0 Enhancements, accessed February 25, 2020, at http://usgsr.github.io/EGRET/articles/Enhancements.html. 
Hirsch, R.M., Moyer, D.L., and Archfield, S.A., 2010, Weighted regressions on time, discharge, and season (WRTDS), with an application to Chesapeake Bay River Inputs 1: Journal of the American Water Resources Association, v. 46, no. 5, p. 857-880, https://doi.org/ 10.1111/j.1752-1688.2010.00482.x.

Horowitz, A.J., Elrick, K.A., Robbins, J.A., and Cook, R.B., 1995, A summary of the effects of mining and related activities on the sediment-trace element geochemistry of Lake Coeur d'Alene, Idaho, USA: Journal of Geochemical Exploration, v. 52, no. 1-2, p. 135-144, https://doi.org/ 10.1016/0375-6742(94)00041-9.

Idaho Department of Environmental Quality, variously dated, Rules of the Department of Environmental Quality: Idaho Department of Environmental Quality, IDAPA 58.01.02, Water Quality Standards, https://adminrules.idaho.gov/ rules/current/58/0102.pdf.

Idaho Department of Environmental Quality and Coeur d'Alene Tribe., 2009, Coeur d'Alene Lake management plan: Idaho Department of Environmental Quality and Coeur d'Alene Tribe, p. 186, https://www.deq.idaho.gov/ media/468377-_water_data_reports_surface_water_water_ bodies_cda_lake_mgmt_plan_final_2009.pdf.

Idaho Department of Environmental Quality and Coeur d'Alene Tribe, 2019, Draft Coeur d'Alene Lake management program-Total phosphorus nutrient inventory, 2004-2013: Idaho Department of Environmental Quality, and Coeur d'Alene Tribe, p. 153.

Lee, C.J., Hirsch, R.M., and Crawford, C.G., 2019, An evaluation of methods for computing annual water-quality loads: U.S. Geological Survey Scientific Investigations Report 2019-5084, p. 1-84, accessed September 26, 2019, at https://doi.org/10.3133/sir20195084.

Lee, C.J., Hirsch, R.M., Schwarz, G.E., Holtschlag, D.J., Preston, S.D., Crawford, C.G., and Vecchia, A.V., 2016, An evaluation of methods for estimating decadal stream loads: Journal of Hydrology (Amsterdam), v. 542, p. 185-203, https://dx.doi.org/https://doi.org/10.1016/ j.jhydrol.2016.08.059.

Lee, C.J., Murphy, J.C., Crawford, C.G., and Deacon, J.R., 2017, Methods for computing water-quality loads at sites in the U.S. Geological Survey National Water Quality Network: U.S. Geological Survey Open-File Report 2017-1120, http://pubs.er.usgs.gov/publication/ ofr20171120.

Levesque, V.A., and Oberg, K.A., 2012, Computing discharge using the index velocity method: US Geological Survey Techniques and Methods 3-A23, 148 p., https://doi.org/ $10.3133 / \mathrm{tm} 3 \mathrm{~A} 23$
Lewis, R.S., and Frost, T.P., 2005, Major oxide and trace element analyses for igneous and metamorphic rock samples from northern and central Idaho: Idaho Geological Survey, Digital Analytical Data-DAD-2.

Long, K.R., 1998, Production and disposal of mill tailings in the Coeur D'Alene mining region, Shoshone County, Idaho-Preliminary estimates: U.S. Geological Survey Open-File Report 98-595, 14 p., http://pubs.er.usgs.gov/ publication/ofr98595.

Maupin, M.A., and Weakland, R.J., 2009, Water budgets for Coeur d'Alene Lake, Idaho, water years 2000-2005: U.S. Geological Survey 2009-5184, 17 p., http://pubs.er.usgs.gov/publication/sir20095184.

McBride, G.B., 2019, Has water quality improved or been maintained?-A quantitative assessment procedure: Journal of Environmental Quality, v. 48, no. 2, p. 412-420, https://doi.org/10.2134/jeq2018.03.0101.

Morlock, S.E., Nguyen, H.T., and Ross, J.H., 2002, Feasibility of acoustic Doppler velocity meters for the production of discharge records from U.S. Geological Survey streamflowgaging stations: U.S. Geological Survey Water Resources Investigations Report 2001-4157, 1-56 p., accessed February 18, 2020, at http://pubs.er.usgs.gov/publication/ wri20014157.

Mueller, D.K., Schertz, T.L., Martin, J.D., and Sandstrom, M.W., 2015, Design, analysis, and interpretation of field quality-control data for water-sampling projects: U.S. Geological Survey Techniques and Methods 4-C4, 65 p, at http://pubs.er.usgs.gov/publication/tm4C4.

Mueller, D.S., Wagner, C.R., Rehmel, M.S., Oberg, K.A., and Rainville, F., 2013, Measuring discharge with acoustic Doppler current profilers from a moving boat: U.S. Geological Survey Techniques and Methods 3-A22, 116 p., http://pubs.er.usgs.gov/publication/tm3A22.

The National Academies Press, 2005, Superfund and mining megasites-Lessons learned from the Coeur d'Alene River Basin: Washington, DC, The National Academies Press, 504 p, http://citeseerx.ist.psu.edu/viewdoc/download?doi= 10.1.1.112.889\&rep=rep1\&type=pdf.

Nielsen, J.P., 1999, Record extension and streamflow statistics for the Pleasant River, Maine: U.S. Geological Survey Water Resources Investigations Report 99-4078, http://pubs.er.usgs.gov/publication/wri994078.

Oberg, K.A., Morlock, S.E., and Caldwell, W.S., 2005, Quality-assurance plan for discharge measurements using acoustic Doppler current profilers: U.S. Geological Survey Scientific Investigations Report 2005-5183, 41 p., http://pubs.er.usgs.gov/publication/sir20055183. 
Oelsner, G.P., Sprague, L.A., Murphy, J.C., Zuellig, R.E., Johnson, H.M., Ryberg, K.R., Falcone, J.A., Stets, E.G., Vecchia, A.V., Riskin, M.L., De Cicco, L.A., Mills, T.J., and Farmer, W.H., 2017, Water-quality trends in the nation's rivers and streams, 1972-2012 - Data preparation, statistical methods, and trend results: U.S. Geological Survey Scientific Investigations Report 2017-5006, 158 p., http://pubs.er.usgs.gov/publication/sir20175006.

Paul, A.P., Garbarino, J.R., Olsen, L.D., Rosen, M.R., Mebane, C.A., and Struzeski, T.M., 2016, Potential sources of analytical bias and error in selected trace element data-quality analyses: U.S. Geological Survey Scientific Investigations Report 2016-5135, 68 p., http://pubs.er.usgs.gov/ publication/sir20165135.

Pritt, J.W., and Raese, J.W., 1995, Quality assurance/quality control manual-National Water Quality Laboratory: U.S. Geological Survey Open-File Report 95-443, 35 p., http://pubs.er.usgs.gov/publication/ofr95443.

R Core Team, 2019, R-A language and environment for statistical computing: Vienna, Austria, R Foundation for Statistical Computing, web, https:/www.r-project.org/.

Rantz, S.E., 1982, Measurement and computation of streamflow-Volume 1, measurement of stage and discharge: U.S. Geological Survey Water Supply Paper 2175, p. 285-631, https://pubs.er.usgs.gov/publication/wsp2175.

Runkel, R.L., Crawford, C.G., and Cohn, T.A., 2004, Load estimator (LOADEST) - A FORTRAN program for estimating constituent loads in streams and rivers: U.S. Geological Survey Techniques and Methods 4-A5, 75 p., http://pubs.er.usgs.gov/publication/tm4A5.

Sauer, V.B., and Turnipseed, D.P., 2010, Stage measurement at gaging stations: U.S. Geological Survey Techniques and Methods 3-A7, 45 p., http://pubs.er.usgs.gov/ publication/tm3A7.

Sprague, L.A., Hirsch, R.M., and Aulenbach, B.T., 2011, Nitrate in the Mississippi River and its tributaries, 1980 to 2008-Are we making progress?: Environmental Science \& Technology, v. 45, no. 17, p. 7209-7216, https://doi.org/ 10.1021/es201221s.

Springer, D., 1997, Historic mineral production in the greater Coeur d'Alene mining region, Idaho: GeoNote, v. 39, p. 1.

Turnipseed, D.P., and Sauer, V.B., 2010, Discharge measurements at gaging stations: U.S. Geological Survey Techniques and Methods 3-A8, 87 p., http://pubs.er.usgs.gov/publication/tm3A8.
URS Grenier Inc., and CH2M HILL, 2001, Final (revision 2) remedial investigation report for the Coeur d'Alene Basin remedial investigation/feasibility study: URS Grenier, Inc., and CH2M HILL, prepared for US Environmental Protection Agency.

U.S. Environmental Protection Agency, 1992, Superfund record of decision-Bunker Hill Mining \& Metallurgical Complex, ID: U.S. Environmental Protection Agency, Office of Emergency and Remedial Response, v. EPA/ROD/ R10-92-041, p. 165.

U.S. Environmental Protection Agency, 2002, The Bunker Hill Mining and Metallurgical Complex Operable Unit 3, record of decision: U.S. Environmental Protection Agency, 527 p., https://nepis.epa.gov.

U.S. Environmental Protection Agency, 2012a, Final focused feasibility study report, Upper Basin of the Coeur d'Alene River, Bunker Hill Mining and Metallurgical Complex Superfund Site: U.S. Environmental Protection Agency, 628 p.

U.S. Environmental Protection Agency, 2012b, Interim record of decision (ROD) amendment, Upper Basin of the Coeur d'Alene River, Bunker Hill Mining and Metallurgical Complex Superfund Site: U.S. Environmental Protection Agency, 488 p., https://semspub.epa.gov/work/10/ 664107.pdf.

U.S. Geological Survey, 1992, Programs and plans-Quality of existing dissolved trace-element data: U.S. Geological Survey Office of Water Quality Technical Memorandum 92.05, accessed January 22, 2020, at https://water.usgs.gov/ $\mathrm{admin} / \mathrm{memo} / \mathrm{QW} / \mathrm{qw} 92.05 . \mathrm{html}$.

U.S. Geological Survey, 1993, Trace-element contamination, findings of study on the cleaning of sampler caps, nozzles, bottles, and bags for trace-element work at the part-per-billion level: U.S. Geological Survey Office of Water Quality Technical Memorandum 93.06, accessed January 22, 2020, at https://water.usgs.gov/admin/memo/ QW/qw93.06.html.

U.S. Geological Survey, 2016a, Guidance on annotating results affected by contamination bias, with examples for water samples affected by $\mathrm{Co}$ and $\mathrm{Mn}$ Contamination from high-capacity capsule filters: U.S. Geological Survey Office of Water Quality Technical Memorandum 2016.05, 9 p., https://water.usgs.gov/admin/memo/QW/qw2016.05.pdf.

U.S. Geological Survey, 2016b, Load Estimator (LOADEST) - A program for estimating constituent loads in streams and rivers: U.S. Geological Survey, web, https://water.usgs.gov/software/loadest/ 
U.S. Geological Survey, 2016c, The StreamStats Program for Idaho: U.S. Geological Survey Streamflow Statistics and Spatial Analysis Tools for Water-Resources Applications, accessed February 12, 2020, at https://water.usgs.gov/osw/ streamstats/idaho.html.

U.S. Geological Survey, 2020, National Water Information System (NWIS): U.S. Geological Survey, web interface, accessed January 2020 at http://dx.doi.org/10.5066/ F7P55KJN.

U.S. Geological Survey, variously dated, National field manual for the collection of water-quality data: U.S. Geological Survey Techniques of Water-Resources Investigations, book 9, chaps. A1-A10, https://pubs.water.usgs.gov/twri9A.

Withers, P.J.A., and Jarvie, H.P., 2008, Delivery and cycling of phosphorus in rivers - A review: The Science of the Total Environment, v. 400, no. 1-3, p. 379-395, http://dx.doi.org/ 10.1016/j.scitotenv.2008.08.002.

Wood, M.S., and Beckwith, M.A., 2008, Coeur d'Alene Lake, Idaho-Insights gained from limnological studies of 1991-92 and 2004-06: U.S. Geological Survey Scientific Investigations Report 2008-5168, 41 p., http://pubs.er.usgs.gov/publication/sir20085168.
Woods, P.F., and Beckwith, M.A., 1997, Nutrient and traceelement enrichment of Coeur d'Alene Lake, Idaho: U.S. Geological Survey Water Supply Paper 2485, 93 p., http://pubs.er.usgs.gov/publication/wsp2485.

Zhang, Q., and Hirsch, R.M., 2019, River water-quality concentration and flux estimation can be improved by accounting for serial correlation through an autoregressive model: Water Resources Research, v. 55, issue 11, https://dx.doi. org/10.1029/2019wr025338.

Zinsser, L.M., 2018, Coeur d'Alene Basin Environmental Monitoring Program, surface water, northern IdahoAnnual data summary, water year 2017: U.S. Geological Survey Open-File Report 2018-1113, 24 p., accessed April 6, 2020, at https://doi.org/10.3133/ofr20181113.

Zinsser, L.M., 2019, Trace metal and nutrient loads from groundwater seepage into the South Fork Coeur d'Alene River near Smelterville, northern Idaho, 2017: U.S. Geological Survey Scientific Investigations Report 2019-5113, 32 p., accessed April 6, 2020, at https://doi.org/ $10.3133 /$ sir20195113.

Zinsser, L.M., 2020, WRTDS annual concentrations, loads and statistical trend likelihoods for sites in the Spokane River watershed, water years 1990-2018: U.S. Geological Survey data release, https://doi.org/10.5066/P91LNE8J. 


\section{Appendix 1. Summary Graphs Showing Weighted Regressions on Time, Discharge and Season (WRTDS) and Weighted Regressions on Time, Discharge and Season with Kalman Filtering (WRTDS_K) Modeled Annual Concentrations and Loads}

This appendix contains graphs showing annual mean concentrations and annual total loads and flow-normalized annual mean concentrations and annual total loads derived from the WRTDS and WRTDS_K models for each modeled site and constituent. The graphs can be accessed at https://doi.org/10.3133/sir20205096. Site locations can be seen in figure 1 in the main body of this report. 
Trends in trace Metals and nutrients in the Coeur d'Alene River Basin

\section{Appendix 2. Model Diagnostics}

This appendix contains WRTDS model diagnostic graphs showing each modeled constituent for each modeled site. The graphs can be accessed at https://doi.org/10.3133/sir20205096. Site locations can be seen in figure 1 in the main body of this report. 
Publishing support provided by the U.S. Geological Survey Science Publishing Network, Tacoma Publishing Service Center For more information concerning the research in this report, contact the Director, Idaho Water Science Center U.S. Geological Survey 230 Collins $\mathrm{Rd}$

Boise, Idaho 83702-4520

https://www.usgs.gov/centers/id-water 
